\title{
Preliminary Geologic Framework Developed for a Proposed Environmental Monitoring Study of a Deep, Unconventional Marcellus Shale Drill Site, Washington County, Pennsylvania
}

Open-File Report 2018-1057 



\section{Preliminary Geologic Framework Developed for a Proposed Environmental Monitoring Study of a Deep, Unconventional Marcellus Shale Drill Site, Washington County, Pennsylvania}

By Robert G. Stamm

Open-File Report 2018-1057 


\title{
U.S. Department of the Interior \\ RYAN K. ZINKE, Secretary
}

\author{
U.S. Geological Survey \\ James F. Reilly II, Director
}

U.S. Geological Survey, Reston, Virginia: 2018

For more information on the USGS - the Federal source for science about the Earth, its natural and living resources, natural hazards, and the environment-visit https://www.usgs.gov or call 1-888-ASK-USGS.

For an overview of USGS information products, including maps, imagery, and publications,

visit https://store.usgs.gov.

Any use of trade, firm, or product names is for descriptive purposes only and does not imply endorsement by the U.S. Government.

Although this information product, for the most part, is in the public domain, it also may contain copyrighted materials as noted in the text. Permission to reproduce copyrighted items must be secured from the copyright owner.

Suggested citation:

Stamm, R.G., 2018, Preliminary geologic framework developed for a proposed environmental monitoring study of a deep, unconventional Marcellus Shale drill site, Washington County, Pennsylvania: U.S. Geological Survey Open-File Report 2018-1057, 49 p., https://doi.org/10.3133/ofr20181057.

ISSN 2331-1258 (online) 


\section{Contents}

Generalized Background Information of Prospective Case Study ..................................................1

Range Resources MCC Partners L.P. Units 1-5H ("RR-MCC”) Drill Site .............................................

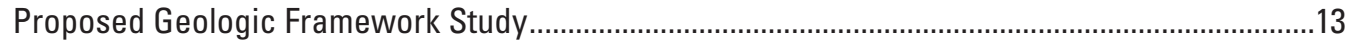

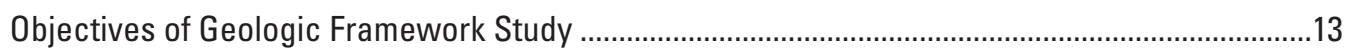

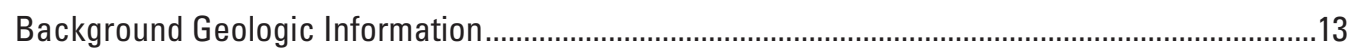

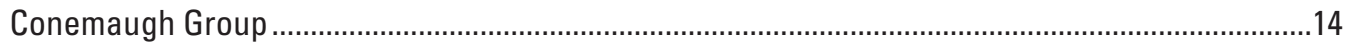

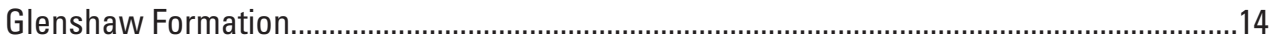

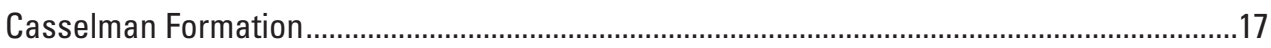

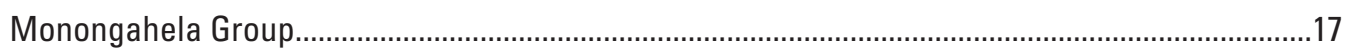

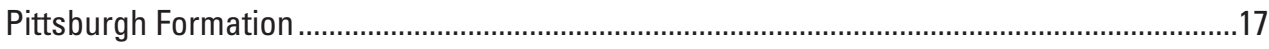

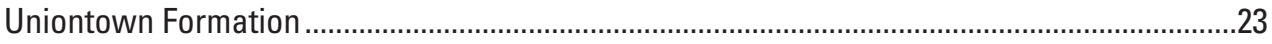

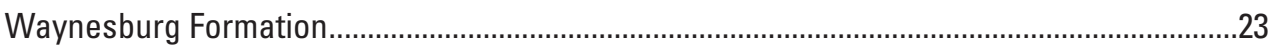

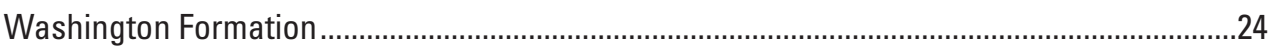

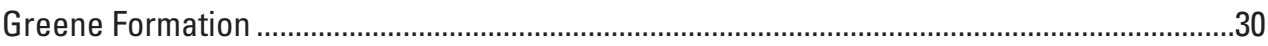

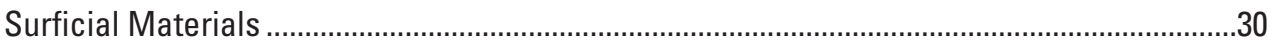

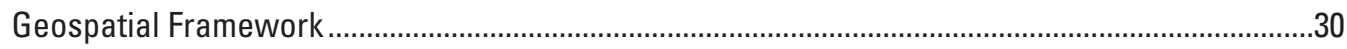

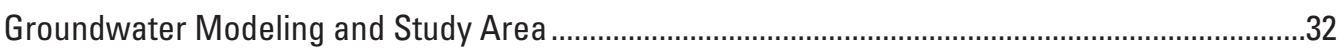

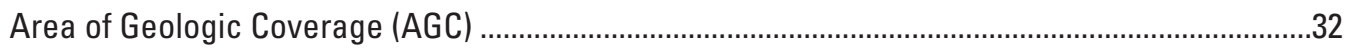

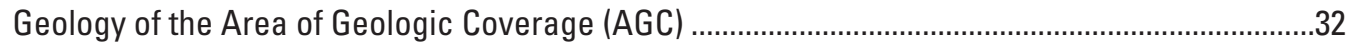

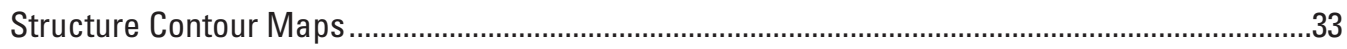

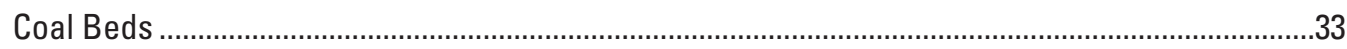

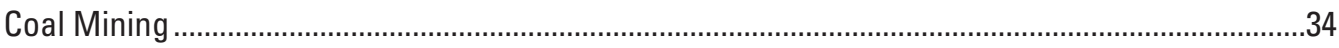

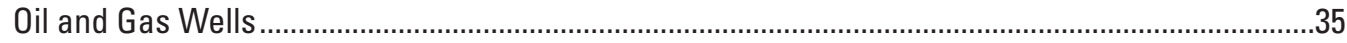

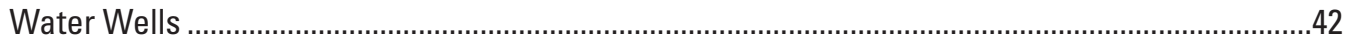

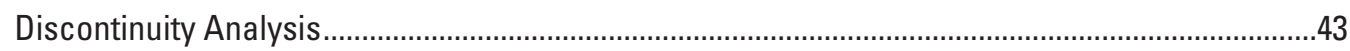

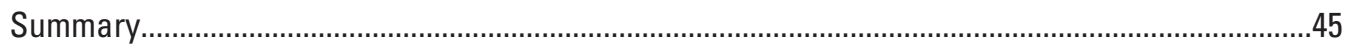

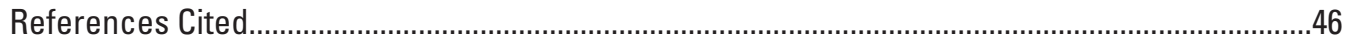

Appendix 1. Lithologic Descriptions of Stratigraphic Units Exposed in the Avella 7.5-Minute Quadrangle, Washington County, Pennsylvania …………................................................4

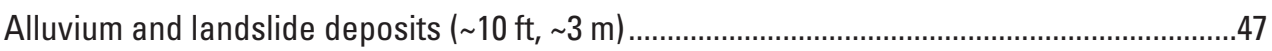

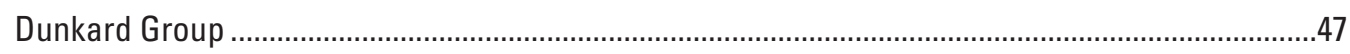

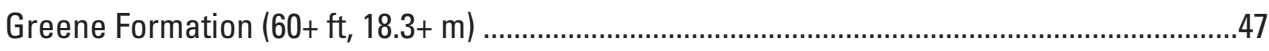

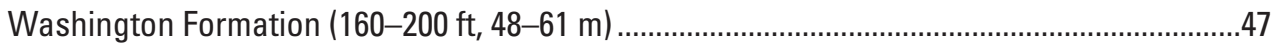

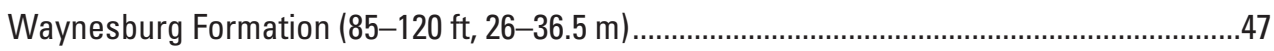

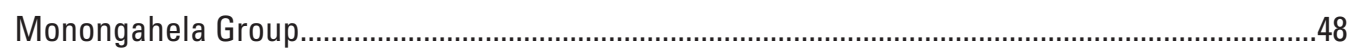

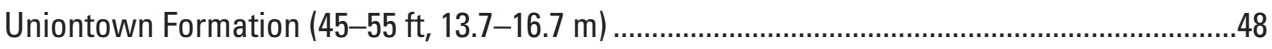

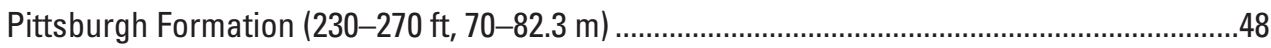

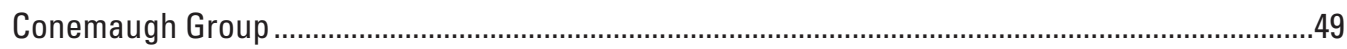

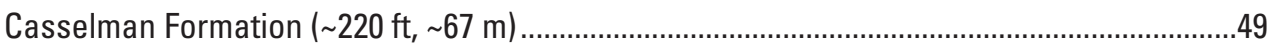

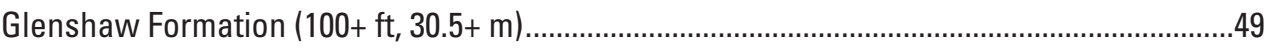




\section{Figures}

1. Map showing the location of the RR-MCC deep, unconventional Marcellus Shale drill site location

2. Map of Washington County, Pennsylvania, showing the locations of unconventional horizontal gas wells and unconventional vertical gas wells spudded from January 1, 2000, to January 6, 2015

3. Overview satellite image of the area of geologic coverage (AGC) showing the location of the RR-MCC drill site.

4. Overview and close-up satellite imagery showing the access road, drill pad working area, and proposed borehole leg traces of the five wells at the RR-MCC drill site..........9

5-7. Maps showing-

5. The proposed locations of the shallow, intermediate, and deep groundwater monitoring wells.

6. The boundary of the groundwater modeling and study area. A, Proposed boundary of the groundwater modeling and study area shown on the U.S. Geological Survey Avella and Burgettstown 7.5-minute topographic map. $B$, Digitized boundary of the groundwater modeling and study area overlain on the 20 -ft-contour-interval topography and watershed boundaries.

7. The area of the proposed groundwater modeling and study area and the area of geologic coverage (AGC) overlain on the best available 1:24,000-scale geologic map of the

Avella 7.5-minute quadrangle by Schweinfurth (1976)

8. Idealized stratigraphic column of the surface and subsurface Mississippian, Pennsylvanian, and Permian age formations of Washington County, Pennsylvania .16

9. Map showing the distribution of the Casselman Formation as both surface and subsurface occurrences in the larger area of geologic coverage (AGC) and the proposed groundwater modeling and study area......

10. Bedrock geologic map and cross section within the area of geologic coverage (AGC). $A$, Bedrock geologic map of the AGC that is largely digitized from Schweinfurth (1976). $B$, Generalized northwest (NW) to southeast (SE) cross section.

11-19. Maps showing-

11. The distribution of the Pittsburgh Formation as both surface and subsurface occurrences in the larger area of geologic coverage $(A G C)$ and the proposed groundwater modeling and study area

12. The distribution of the Uniontown Formation as both surface and subsurface occurrences in the larger area of geologic coverage (AGC) and the proposed groundwater modeling and study area

13. The distribution of the Waynesburg Formation as both surface and subsurface occurrences in the larger area of geologic coverage (AGC) and the proposed groundwater modeling and study area

14. The subsurface extent of the Pittsburgh coal bed overlain with the known extent of surface and subsurface mines in the Pittsburgh coal bed and overlying Waynesburg coal bed.....

15. The distribution of the lower (Pwl), middle (Pwm), and upper (Pwu) limestone members of the Washington Formation in the larger area of geologic coverage (AGC) and the proposed groundwater modeling and study area.

16. The subsurface extent of the Pittsburgh coal bed overlain with (1) known surface and subsurface mines in the Pittsburgh coal bed and Waynesburg coal bed; and (2) the locations of historic oil and gas wells, as well as the locations of dry holes....... 
17. The locations of domestic water wells in the topography and on bedrock geology of the small watersheds within the area of geologic coverage (AGC). $A$, Map showing the locations of domestic water wells in the topography and small watershed areas of the AGC. B, Map showing the locations of domestic water wells plotted in the surface bedrock geology of the AGC.

18. The locations of active oil and gas wells and dry holes drilled prior to deep, unconventional Marcellus shale-gas drilling within the area of geologic coverage (AGC)...........41

19. Hill-shade topography of the area of geologic coverage (AGC) showing the control of local, small-scale fracture lineaments on streams and hill-slope incision

\section{Tables}

1. Locality and depth data for the Unit $1 \mathrm{H}$ to Unit $5 \mathrm{H}$ wells at the RR-MCC drill site ............4

2. General information and data on hydraulic fracturing and waste generated from drilling of the Unit $1 \mathrm{H}$ to Unit $5 \mathrm{H}$ wells at the RR-MCC drill site...................................................

3. Production data for the Unit $1 \mathrm{H}$ to Unit $5 \mathrm{H}$ wells at the RR-MCC drill site .......................5

4. List of sources and links to online digital resources used to compile the geospatial part of this report .................................................................................................................. 


\section{Conversion Factors}

U.S. customary units to International System of Units

\begin{tabular}{|c|c|c|}
\hline Multiply & By & To obtain \\
\hline \multicolumn{3}{|c|}{ Length } \\
\hline inch (in.) & 2.54 & centimeter $(\mathrm{cm})$ \\
\hline foot $(\mathrm{ft})$ & 0.3048 & meter $(\mathrm{m})$ \\
\hline mile (mi) & 1.609 & kilometer (km) \\
\hline \multicolumn{3}{|c|}{ Area } \\
\hline acre & 4,047 & square meter $\left(\mathrm{m}^{2}\right)$ \\
\hline acre & 0.4047 & hectare (ha) \\
\hline acre & 0.4047 & square hectometer $\left(\mathrm{hm}^{2}\right)$ \\
\hline acre & 0.004047 & square kilometer $\left(\mathrm{km}^{2}\right)$ \\
\hline square mile $\left(\mathrm{mi}^{2}\right)$ & 259.0 & hectare (ha) \\
\hline square mile $\left(\mathrm{mi}^{2}\right)$ & 2.590 & square kilometer $\left(\mathrm{km}^{2}\right)$ \\
\hline \multicolumn{3}{|c|}{ Volume } \\
\hline $\begin{array}{l}\text { barrel (bbl; petroleum, } \\
1 \text { barrel=42 gal) }\end{array}$ & 0.1590 & cubic meter $\left(\mathrm{m}^{3}\right)$ \\
\hline gallon (gal) & 3.785 & liter (L) \\
\hline gallon (gal) & 0.003785 & cubic meter $\left(\mathrm{m}^{3}\right)$ \\
\hline gallon (gal) & 3.785 & cubic decimeter $\left(\mathrm{dm}^{3}\right)$ \\
\hline
\end{tabular}

International System of Units to U.S. customary units

\begin{tabular}{|c|c|c|}
\hline Multiply & By & To obtain \\
\hline \multicolumn{3}{|c|}{ Length } \\
\hline centimeter $(\mathrm{cm})$ & 0.3937 & inch (in.) \\
\hline meter (m) & 3.281 & foot $(\mathrm{ft})$ \\
\hline kilometer $(\mathrm{km})$ & 0.6214 & mile (mi) \\
\hline \multicolumn{3}{|c|}{ Area } \\
\hline square meter $\left(\mathrm{m}^{2}\right)$ & 0.0002471 & acre \\
\hline hectare (ha) & 2.471 & acre \\
\hline $\begin{array}{l}\text { square hectometer } \\
\quad\left(\mathrm{hm}^{2}\right)\end{array}$ & 2.471 & acre \\
\hline square kilometer $\left(\mathrm{km}^{2}\right)$ & 247.1 & acre \\
\hline hectare (ha) & 0.003861 & square mile $\left(\mathrm{mi}^{2}\right)$ \\
\hline square kilometer $\left(\mathrm{km}^{2}\right)$ & 0.3861 & square mile $\left(\mathrm{mi}^{2}\right)$ \\
\hline \multicolumn{3}{|c|}{ Volume } \\
\hline cubic meter $\left(\mathrm{m}^{3}\right)$ & 6.290 & $\begin{array}{l}\text { barrel (petroleum, } 1 \text { barrel } \\
\quad=42 \text { gal) }\end{array}$ \\
\hline liter $(\mathrm{L})$ & 0.2642 & gallon (gal) \\
\hline cubic meter $\left(\mathrm{m}^{3}\right)$ & 264.2 & gallon (gal) \\
\hline cubic decimeter $\left(\mathrm{dm}^{3}\right)$ & 0.2642 & gallon (gal) \\
\hline
\end{tabular}




\title{
Preliminary Geologic Framework Developed for a Proposed Environmental Monitoring Study of a Deep, Unconventional Marcellus Shale Drill Site, Washington County, Pennsylvania
}

\author{
By Robert G. Stamm
}

\section{Generalized Background Information of Prospective Case Study}

In the fall of 2011, the U.S. Geological Survey (USGS) was afforded an opportunity to participate in an environmental monitoring study of the potential impacts of a deep, unconventional Marcellus Shale hydraulic fracturing site. The drill site of the prospective case study is the "Range Resources MCC Partners L.P. Units 1-5 $\mathrm{H}^{1}$ " location (also referred to in this report as the "RR-MCC" drill site), located in Washington County, southwestern Pennsylvania. Specifically, the USGS was approached to provide a geologic framework that would (1) provide geologic parameters for the proposed area of a localized groundwater circulation model, and (2) provide potential information for the siting of both shallow and deep groundwater monitoring wells located near the drill pad and the deviated drill legs.

The lead organization of the prospective case study of the RR-MCC drill site was the Groundwater and Ecosystems Restoration Division (GWERD) of the U.S. Environmental Protection Agency. Aside from the USGS, additional partners/ participants were to include the Department of Energy, the Pennsylvania Geological Survey, the Pennsylvania Department of Environmental Protection, and the developer Range Resources LLC. During the initial cooperative phase, GWERD, with input from the participating agencies, drafted a Quality Assurance Project Plan (QAPP) that proposed much of the objectives, tasks, sampling and analytical procedures, and documentation of results.

Later in 2012, the proposed cooperative agreement between the aforementioned partners and the associated land

"Units 1-5H" in the drill-site name refers to the five individual wells at the "Range Resources MCC Partners L.P. Units 1-5H" drill site location. The original name of the five wells are "MCC Partners Unit \#1H," "MCC Partners Unit \#2H" etc., but are shortened hereinafter in this report to just "Unit $1 \mathrm{H}$ " (or "1H"), "Unit $2 \mathrm{H}$ " (or " $2 \mathrm{H}$ "), etc., for brevity. owners for a monitoring program at the drill site was not executed. Therefore, the prospective case study of the RR-MCC site was terminated and no installation of groundwater monitoring wells nor the collection of nearby soil, stream sediment, and surface-water samples were made.

Prior to the completion of the QAPP and termination of the perspective case study the geologic framework was rapidly conducted and nearly completed. This was done for three principal reasons. First, there was an immediate need to know the distribution of the relatively undisturbed surface to near-surface bedrock geology and unconsolidated materials for the collection of baseline surface data prior to drill site development (drill pad access road, drill pad leveling) and later during monitoring associated with well drilling, well development, and well production. Second, it was necessary to know the bedrock geology to support the siting of: (1) multiple shallow groundwater monitoring wells (possibly as many as four) surrounding and located immediately adjacent to the drill pad, and (2) deep groundwater monitoring wells (possibly two) located at distance from the drill pad with one possibly being sited along one of the deviated production drill legs. Lastly, the framework geology would provide the lateral extent, thickness, lithology, and expected discontinuities of geologic units (to be parsed or grouped as hydrostratigraphic units) and regional structure trends as inputs into the groundwater model.

This paper provides the methodology of geologic data accumulation and aggregation, and its integration into a geographic information system (GIS) based program. The GIS program will allow multiple data to be exported in various formats (shapefiles [.shp], database files [.dbf], and Keyhole Markup Language files [.KML]) for use in surface and subsurface geologic site characterization, for sampling strategies, and for inputs for groundwater modeling. 


\section{Range Resources MCC Partners L.P. Units 1-5H ("RR-MCC") Drill Site}

Since the cancellation of the prospective case study, the five wells of the RR-MCC site have been drilled, developed, and are currently in active production. The following section provides some information on well localities, well leg trends and distances, well depths, hydraulic fracturing data (chemicals used, included as pdf's), development waste, and recent gas and condensate production.

The RR-MCC drill site is located in Jefferson Township of Washington County, southwestern Pennsylvania (figs. 1 and 2). The drill site consists of five deep unconventional wells that target the tight shale-gas of the Devonian Marcellus Shale. The spud date, or initiation of drilling, of Unit $1 \mathrm{H}$, Unit $2 \mathrm{H}$, Unit $4 \mathrm{H}$, and Unit $5 \mathrm{H}$ was June 21,2013 , and Unit $3 \mathrm{H}$ started a day later on June 22, 2013. The latitude and longitude coordinates of the individual well heads and their terminations (the latter given as surface locations) and their true vertical depths are provided in table 1. True vertical depths of the five wells (http://fracfocus.org/) vary from 5,903 to 5,965 feet (ft) $(1,799-1,818$ meters (m)). Though no well $\log$ information of subsurface lithology (stratigraphic unit and depth) is provided, these final depths will place each of the deviated well legs in the targeted Marcellus Shale.

As an unconventional tight shale-gas play, all horizontal wellbore legs were completed by hydraulic fracture stimulation to enhance production. Table 2 provides available information concerning hydraulic fracturing and the drilling and fracture fluid waste that was generated (data from GWPC and IOGCC (2015), at http://fracfocus.org/). Among all wellbores, the hydraulic fracturing process occurred between February 21 and February 23 of 2014 and was completed between March 16 and March 19 of 2014, varying from 21 to 25 days. The volume of water used in hydraulic fracturing among the wells varied from 8.55 million gallons to 10.33 million gallons. This carrier water provides approximately 87.5 percent of the fracturing fluid mass with proppant silica sand amounting to approximately 12.25 percent of the mass, together providing approximately 99.75 percent of the total fracturing fluid mass. The remaining approximately 0.25 percent of the fracturing fluid mass consists of various chemical additives, such as bacterial nutritional supplements, friction reducers, corrosion inhibitors, scale inhibitors, nonemulsifiers, perforation cleaners, and iron chelators, which are conditioning agents for the carrier water, the wellbore, and the downhole hardware.

Available quantities of drilling and hydraulic fracturing waste of the five wells include drill cuttings, drilling fluid, flowback proppant sand, fracturing fluid, and produced fluids (table 2; data from Pennsylvania Department of Environmental Protection [PADEP] (2015), at https://www.paoilandgasreporting.state.pa.us/publicreports/Modules/Welcome/ProdWasteReports.aspx). Among the wellbores, drill cuttings waste varied from 832.87 tons to $1,169.22$ tons, with a total from all wellbores of 4,768.71 tons. Drill cuttings waste was disposed in landfills. Drilling fluid waste among all wellbores varied from 463.43 barrels (bbl) (42 U.S. gallons/bbl) to 3,132.52 bbl, with a total from all wellbores of 9,233.34 bbl. Drilling fluid waste was disposed in landfills, reused, or sent to a residual waste processing facility. The total amount of flowback proppant sand waste reported for all wells is 38.91 tons, and it was disposed in landfills. The total amount of fracturing fluid waste reported for all wells is $20,943.44 \mathrm{bbl}$ and it was either reused or sent to a residual waste processing facility. Lastly, produced fluid waste reported for all wellbores totals 26,258.34 bbl. Produced fluids are generated both during and following wellbore completion, they commonly contain no treatment fluids (fracturing fluid), and are of varying and unknown composition due to their interaction with rock minerals and pore water fluids. Produced fluids are either reused or processed at a permitted waste water treatment facility.

Current production information for gas and liquid hydrocarbon condensate, as of this report date, for the five wells at the RR-MCC drill site are given in table 3 (data from PADEP (2015), at http://www.paoilandgasreporting.state.pa.us). Production reporting periods for 2014 are not monthly as they are for 2015, but rather are aggregated into two unequal time periods. Among the five wells, the earliest and shortest reporting period for 2014 is "2014-1," which varies from 48 to 78 days, and the later and longer reporting period for 2014 is "2014-2," which varies from 169 to 184 days. Since production began in early 2014 and continued through May 2015 (a period of approximately 13 to 14 months), the total gas production for all wells is 3,372,505.83 Mcf (million cubic feet) and the total condensate is $171,143.61 \mathrm{bbl}$.

An overview, high resolution satellite image of the area of geologic coverage (AGC) of this report is shown in figure 3. The imagery date is postdrilling and well development. Figure 3 also provides the location of the RR-MCC drill site and the locations of other permitted, deep unconventional Marcellus Shale drill sites, either currently producing or that will be drilled, within the AGC. Figure 4 provides a close-up, high-resolution satellite image of the RR-MCC drill site annotated with the locations of the five well heads, borehole terminations, borehole trends, and 20-foot-contour-interval topography. The following discussion concerning these features of the RR-MCC site is based on mensurated geospatial data imported into (and derived from) Global Mapper version 16 software developed by Blue Marble Geographics.

The drill pad is located on the lower southeast-facing slopes of a narrow northeast- to southwest-trending valley that carries the upper reaches of the North Fork of Cross Creek. Vertical relief along the valley varies from 200 to $240 \mathrm{ft}$ (61 to $73 \mathrm{~m}$ ). The drill pad is located on the crest of a small southeast-trending spur at an elevation of approximately $1,190 \mathrm{ft}(363 \mathrm{~m})$. The spur crest is broadly rounded with a nearly level, south- to southeast-facing slope of 2.5 degrees. To create a level working area at the drill pad, construction involved bench cutting of the upward slope (on the northern margin of the pad) and using spoil to backfill the downward slope (on the lateral and southern margins of the pad). The working area of the level drill pad has 
dimensions of approximately $300 \times 430 \mathrm{ft}(91 \times 131 \mathrm{~m})$ for an area of approximately 2.96 acres $\left(11,984\right.$ square meters $\left.\left(\mathrm{m}^{2}\right)\right)$. The total area of disturbed ground, which includes the drill pad, bench cut, and spoil aprons, is 7.1 acres $\left(28,733 \mathrm{~m}^{2}\right)$. The length of the drill pad access road is approximately $2,756 \mathrm{ft}(840 \mathrm{~m})$ with a surface area of approximately 4.5 acres $\left(18,211 \mathrm{~m}^{2}\right)$.

The five vertical wells are horizontally deviated such that the individual legs have parallel trends to the northwest (bearing 329 degrees). The spacing distance between the horizontal legs varies from 982 to $1,015 \mathrm{ft}$ (300 to $310 \mathrm{~m}$ ) (fig. 4). The coordinates (table 1) of the subsurface termination of each of the five individual well legs are shown in figure 4, with the central well (Unit $3 \mathrm{H}$ ) being the shortest and most direct borehole at a length of $3,425 \mathrm{ft}(1,000 \mathrm{~m})$.

As an unconventional tight shale-gas play, all horizontal well legs were developed by hydraulic fracturing prior to production. Table 2 provides available information concerning the drilling and hydraulic fracturing of the individual wells, such as (1) dates of initiation (start date) and completion (end date), (2) quantity of water and proppant used in the hydraulic fracturing process, and (3) the quantity of drill cutting and waste fracture fluid for the individual wells.

The "Range Resources Renz 1" well, which was spudded in 2003 with a formation target to the Silurian Lockport Dolomite, was the first vertical unconventional well to exploit the tight shale-gas of the Devonian Marcellus Shale. This well, also located in Washington County, is only 8.6 miles (13.8 kilometers $(\mathrm{km})$ ) to the east-southeast of the RR-MMC site of this study.

The primary objective of the case study was to sample soil, stream sediments, and both surface water and groundwater at distances as much as 1-mile radius from the well pad. It was important that sampling be conducted prior to construction of the well pad in order to establish baseline sample characteristics and quality, which is frequently lacking in case studies. Sampling would then continue during (1) drilling, (2) the management and disposal of drill cuttings, (3) bore hole stimulation (hydraulic fracturing), (4) the management and disposal hydraulic fracturing fluids and produced fluids, and lastly, (5) during production of gas and condensates for a period of approximately one year.

The groundwater part of the case study was intended to consist of two parts, (1) groundwater chemistry monitoring, and (2) development of a groundwater flow model. Water samples for groundwater chemistry monitoring were to be taken from both existing domestic wells and from between 5 to 8 newly drilled groundwater monitoring wells. The new monitoring wells would be located in close proximity to the drill pad, at distances of 0.1 to 0.5 miles, and drilled prior to the placement of the deep gas well production pad (fig. 5). The monitoring wells were proposed to be drilled to depths between 100 to $300 \mathrm{ft}$ with one drilled to a depth of 1,500 ft. The location of the monitoring wells would, in part, be dependent on a localized site-specific geologic framework study conducted by the Eastern Geology and Paleoclimate Science Center (EGPSC) of the USGS and, in part, on the location of the production pad and the deep legs of the gas production well. All monitoring well boreholes were expected to be logged by various geophysical, mechanical, and imaging methods.

The groundwater flow model of the proposed case study was to be developed by the Pennsylvania Water Science Center of the USGS. The proposed flow model area is principally bounded by local prominent geographic features, such as major streams that occupy deep valleys or high ridgelines that separate watershed basins (fig. 6A, 6B). These geographic features, in general, are expected to serve as groundwater flow boundaries within the limits of the local relief of the study area, which is approximately $500 \mathrm{ft}$. At depths below the local relief, the flow boundaries may be extended into and interact with adjacent, larger, and more regional groundwater basins. In total, the model area is approximately 16.5 square miles $\left(\mathrm{mi}^{2}\right)$ and it is roughly centered on the production pad. The total depth of the groundwater model has not been determined, but it is expected to be greater than the total local relief of $500 \mathrm{ft}$. 
Table 1. Locality and depth data for the Unit $1 \mathrm{H}$ to Unit $5 \mathrm{H}$ wells at the RR-MCC drill site.

[Data source: Groundwater Protection Council (GWPC) and Interstate Oil and Gas Compact Commission (IOGCC) (2015), at http://fracfocus.org/. Abbreviations: deg., degrees; lat, latitude; long, longitude; min., minutes; sec., seconds]

\begin{tabular}{cccc}
\hline Well & \multicolumn{1}{c}{$\begin{array}{c}\text { Well head location } \\
\text { (in deg. min. sec.) }\end{array}$} & $\begin{array}{c}\text { Subsurface termination (in deg. min. } \\
\text { sec.; given as surface coordinates) }\end{array}$ & $\begin{array}{c}\text { True vertical depth, in feet } \\
\text { (in meters) }\end{array}$ \\
\hline Unit 1H & Lat $40^{\circ} 20^{\prime} 36.67^{\prime \prime}$, Long $80^{\circ} 25^{\prime} 54.58^{\prime \prime}$ & Lat $40^{\circ} 20^{\prime} 55.50^{\prime \prime}$, Long $80^{\circ} 26^{\prime} 39.44^{\prime \prime}$ & $5,903(1,799)$ \\
Unit 2H & Lat $40^{\circ} 20^{\prime} 36.92^{\prime \prime}$, Long $80^{\circ} 25^{\prime} 54.80^{\prime \prime}$ & Lat $40^{\circ} 21^{\prime} 00.79^{\prime \prime}$, Long $80^{\circ} 26^{\prime} 28.82^{\prime \prime}$ & $5,940(1,810)$ \\
Unit 3H & Lat $40^{\circ} 20^{\prime} 37.14^{\prime \prime}$, Long $80^{\circ} 25^{\prime} 55.02^{\prime \prime}$ & Lat $40^{\circ} 21^{\prime} 06.08^{\prime \prime}$, Long $80^{\circ} 26^{\prime} 17.91^{\prime \prime}$ & $5,914(1,802)$ \\
Unit 4H & Lat $40^{\circ} 20^{\prime} 37.39^{\prime \prime}$, Long $80^{\circ} 25^{\prime} 54.58^{\prime \prime}$ & Lat $40^{\circ} 21^{\prime} 11.55^{\prime \prime}$, Long $80^{\circ} 26^{\prime} 07.29^{\prime \prime}$ & $5,909(1,801)$ \\
Unit 5H & Lat $40^{\circ} 20^{\prime} 37.14^{\prime \prime}$, Long $80^{\circ} 25^{\prime} 54.37^{\prime \prime}$ & Lat $40^{\circ} 21^{\prime} 16.84^{\prime \prime}$, Long $80^{\circ} 25^{\prime} 56.13^{\prime \prime}$ & $5,965(1,818)$ \\
\hline
\end{tabular}

Table 2. General information and data on hydraulic fracturing and waste generated from drilling of the Unit $1 \mathrm{H}$ to Unit $5 \mathrm{H}$ wells at the RR-MCC drill site.

[Data sources: "hydraulic fracturing" from Groundwater Protection Council (GWPC) and Interstate Oil and Gas Compact Commission (IOGCC) (2015), at https://fracfocusdata.org/DisclosureSearch/Search.aspx; "drilling and hydraulic fracturing waste" from Pennsylvania Department of Environmental Protection (PADEP) (2015), at https://www.paoilandgasreporting.state.pa.us/publicreports/Modules/Welcome/ProdWasteReports.aspx. Abbreviations: bbl, barrels; frac., fracturing; gal, gallons; \%, percent]

\begin{tabular}{|c|c|c|c|c|c|}
\hline & Unit 1H & Unit 2H & Unit 3H & Unit 4H & Unit 5H \\
\hline \multicolumn{6}{|c|}{ Hydraulic fracturing } \\
\hline Start date & $2 / 21 / 2014$ & $2 / 21 / 2014$ & $2 / 22 / 2014$ & $2 / 21 / 2014$ & $2 / 21 / 2014$ \\
\hline End date & $3 / 17 / 2014$ & $3 / 16 / 2014$ & $3 / 18 / 2014$ & $3 / 19 / 2014$ & $3 / 19 / 2014$ \\
\hline Total days & 24 & 23 & 24 & 26 & 26 \\
\hline Water volume used (gal) & $8,813,068$ & $8,553,988$ & $9,499,392$ & $10,086,169$ & $10,336,291$ \\
\hline Water, $\%$ mass of frac. fluid & 87.61 & 87.59 & 88.10 & 87.29 & 87.85 \\
\hline Silica, $\%$ mass of frac. fluid & 12.15 & 12.17 & 11.65 & 12.47 & 11.90 \\
\hline $\begin{array}{l}\text { Water and silica, total \% mass } \\
\text { of frac. fluid }\end{array}$ & 99.76 & 99.76 & 99.75 & 99.76 & 99.75 \\
\hline \multicolumn{6}{|c|}{ Drilling and hydraulic fracturing waste } \\
\hline Drill cuttings waste (tons) & $1,008.87$ & 832.87 & $1,169.22$ & 852.28 & 905.47 \\
\hline Drilling fluid waste (bbl) & $2,365.39$ & 463.43 & $3,132.52$ & $1,674.00$ & $1,598.00$ \\
\hline Flowback proppant sand (tons) & \multicolumn{5}{|c|}{38.91 (given as total of all wells) } \\
\hline Fracturing fluid waste (bbl) & \multicolumn{5}{|c|}{$20,943.44$ (given as total of all wells) } \\
\hline Produced fluids (bbl) & \multicolumn{5}{|c|}{$26,258.34$ (given as total of all wells) } \\
\hline
\end{tabular}


Table 3. Production data for the Unit $1 \mathrm{H}$ to Unit $5 \mathrm{H}$ wells at the RR-MCC drill site.

[There are two production reporting periods for 2014 among the five wells, the first varies from 48 to 78 days and the second varies from 169 to 184 days. For 2015, the production for each well is reported on a monthly basis. Data source: Pennsylvania Department of Environmental Protection (PADEP) (2015), at http://www.paoilandgasreporting.state.pa.us. Abbreviations: bbl, barrels; Mcf, million cubic feet]

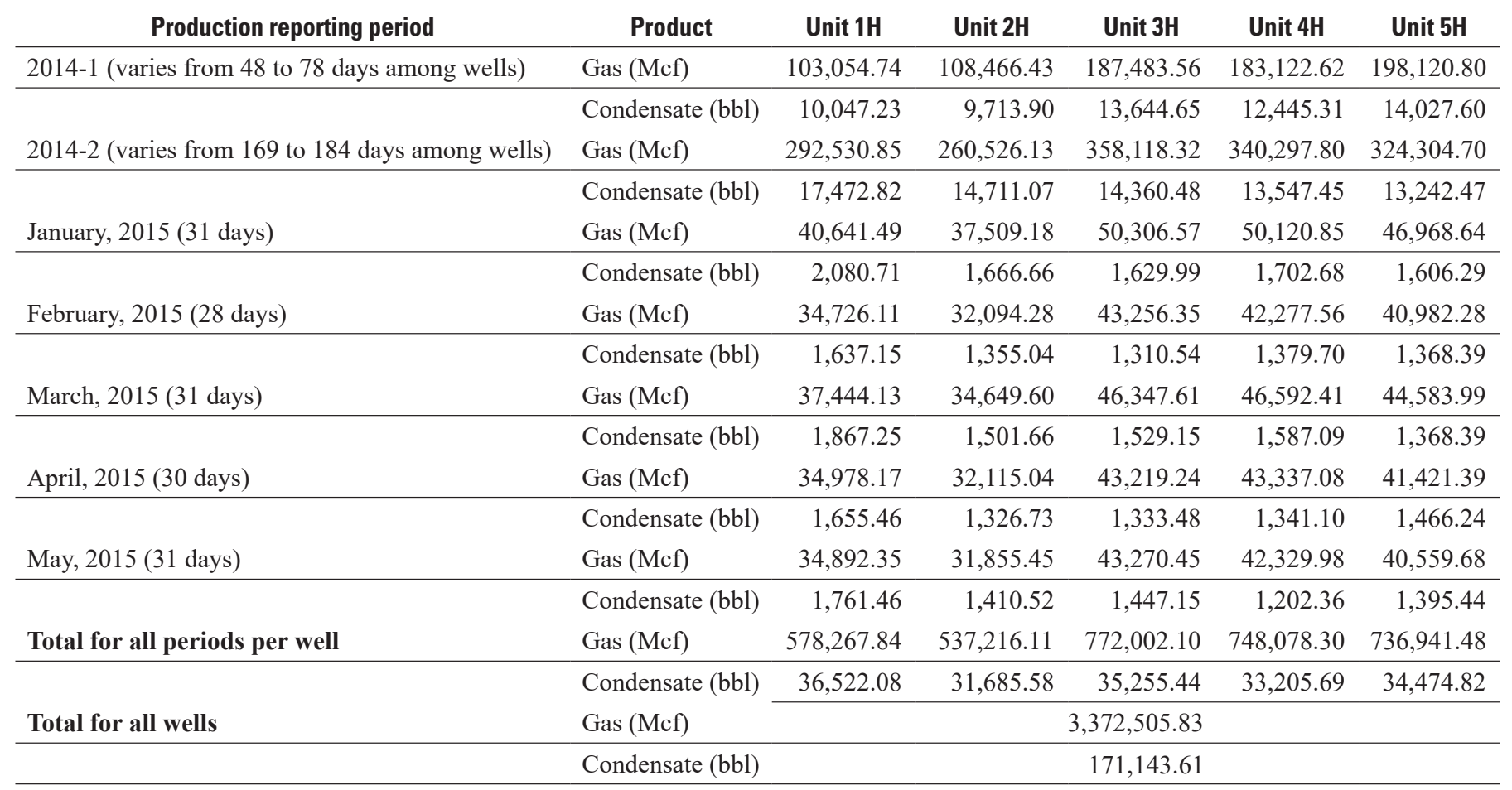



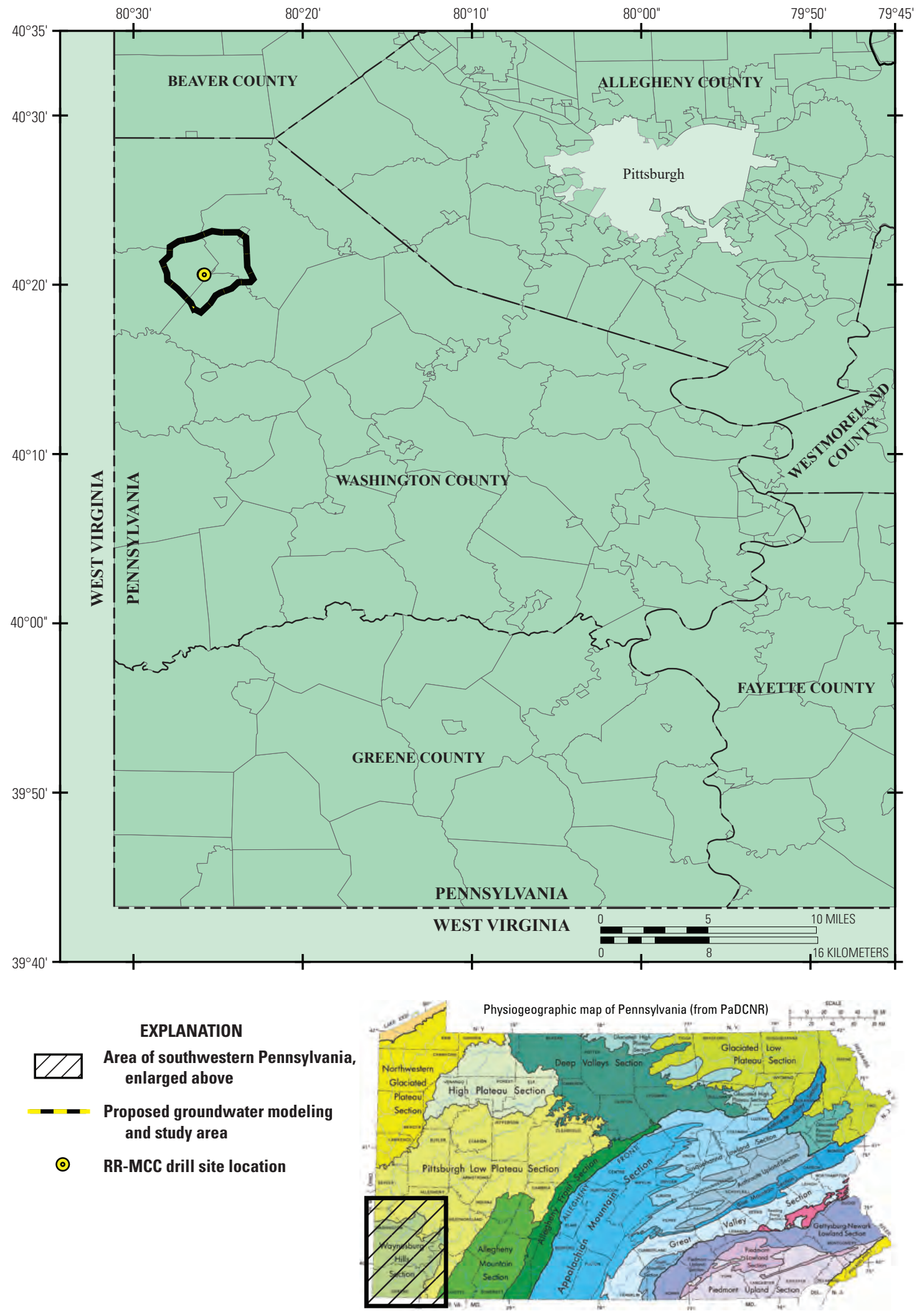

Figure 1. Map showing the location of the RR-MCC deep, unconventional Marcellus Shale drill site location. The site is the location of wells "Unit 1H" to "Unit 5H" in Jefferson Township, Washington County, southwestern Pennsylvania. The proposed groundwater modeling and study area is enclosed by the black and yellow dashed line. Note that the abbreviation "RR-MCC" in the drill site name is short for "Range Resources MCC Partners L.P. Units 1-5H." Additional abbreviation: PaDCNR, Pennsylvania Department of Conservation and Natural Resources. 


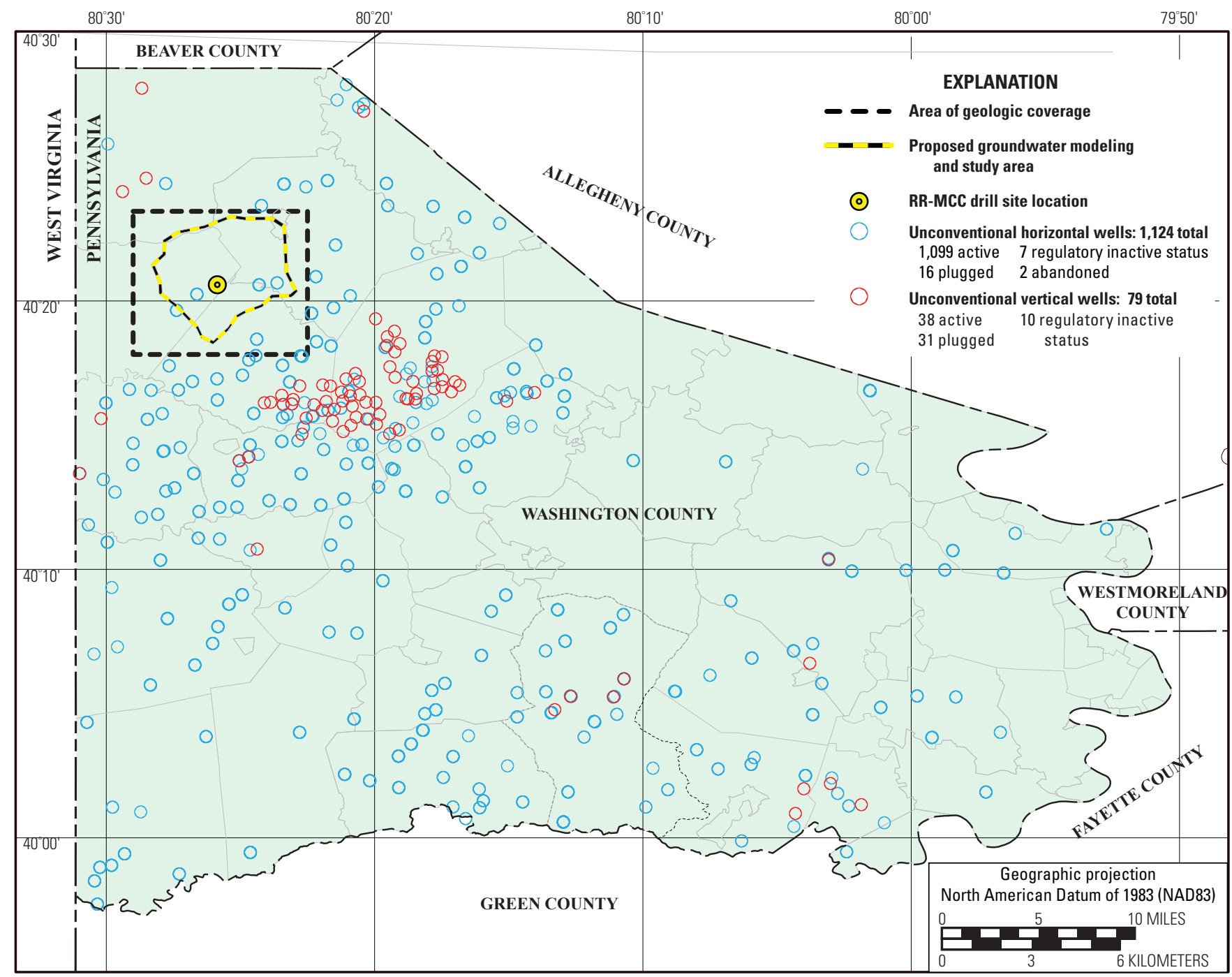

Figure 2. Map of Washington County, Pennsylvania, showing the locations of unconventional horizontal gas wells ( $\mathrm{n}=1,124)$ and unconventional vertical gas wells $(n=79)$ spudded from January 1, 2000, to January 6, 2015 (15.5 years). The location of the area of geologic coverage (AGC) is shown within the black dashed box, and the proposed groundwater modeling and study area (enclosed by black and yellow dashed line) of the RR-MCC property is shown in the northwestern part of the county. Plotted data are from Pennsylvania Department of Environmental Protection (PADEP 2015; http://www.dep.pa.gov/DataandTools/Reports/0il\%20and\%20 Gas\%20Reports/Pages/default.aspx). The small yellow circle is the location of the RR-MCC drill site (location of wells "Unit 1H" to "Unit $5 \mathrm{H}^{\prime \prime}$. Note that the abbreviation "RR-MCC" in the drill site name is short for "Range Resources MCC Partners L.P. Units 1-5H." 


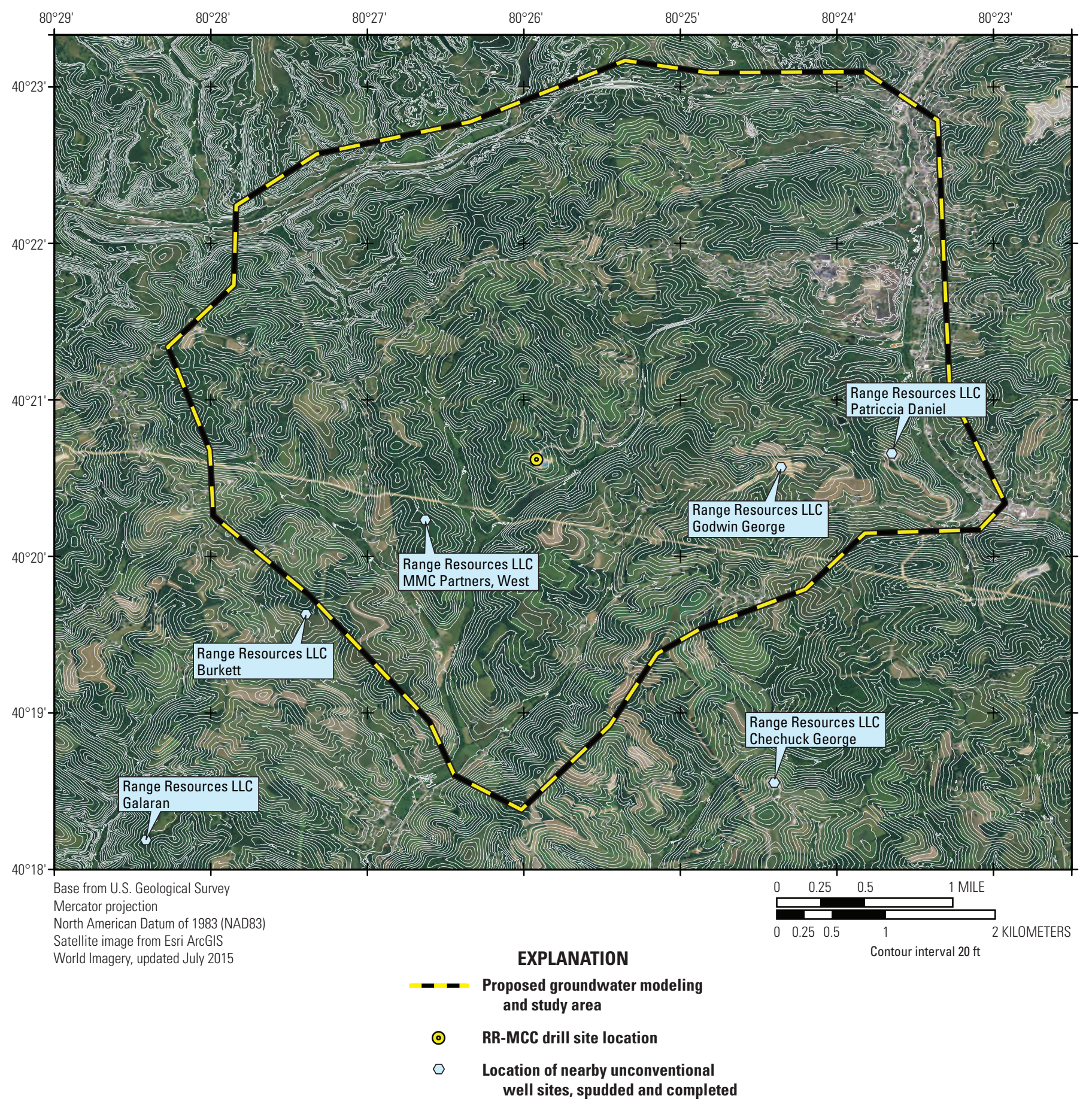

Figure 3. Overview satellite image of the area of geologic coverage (AGC) showing the location of the RR-MCC drill site (location of wells "Unit 1H" to "Unit 5H;" see small yellow circle). Locations of other deep, Marcellus Shale unconventional gas wells that occur within the AGC (all also developed and operated by Range Resources) are shown with small blue hexagons. Well location data are from Pennsylvania Department of Environmental Protection (PADEP) (see table 4 for links to online source). Note that the abbreviation "RR-MCC" in the drill site name is short for "Range Resources MCC Partners L.P. Units 1-5H." 


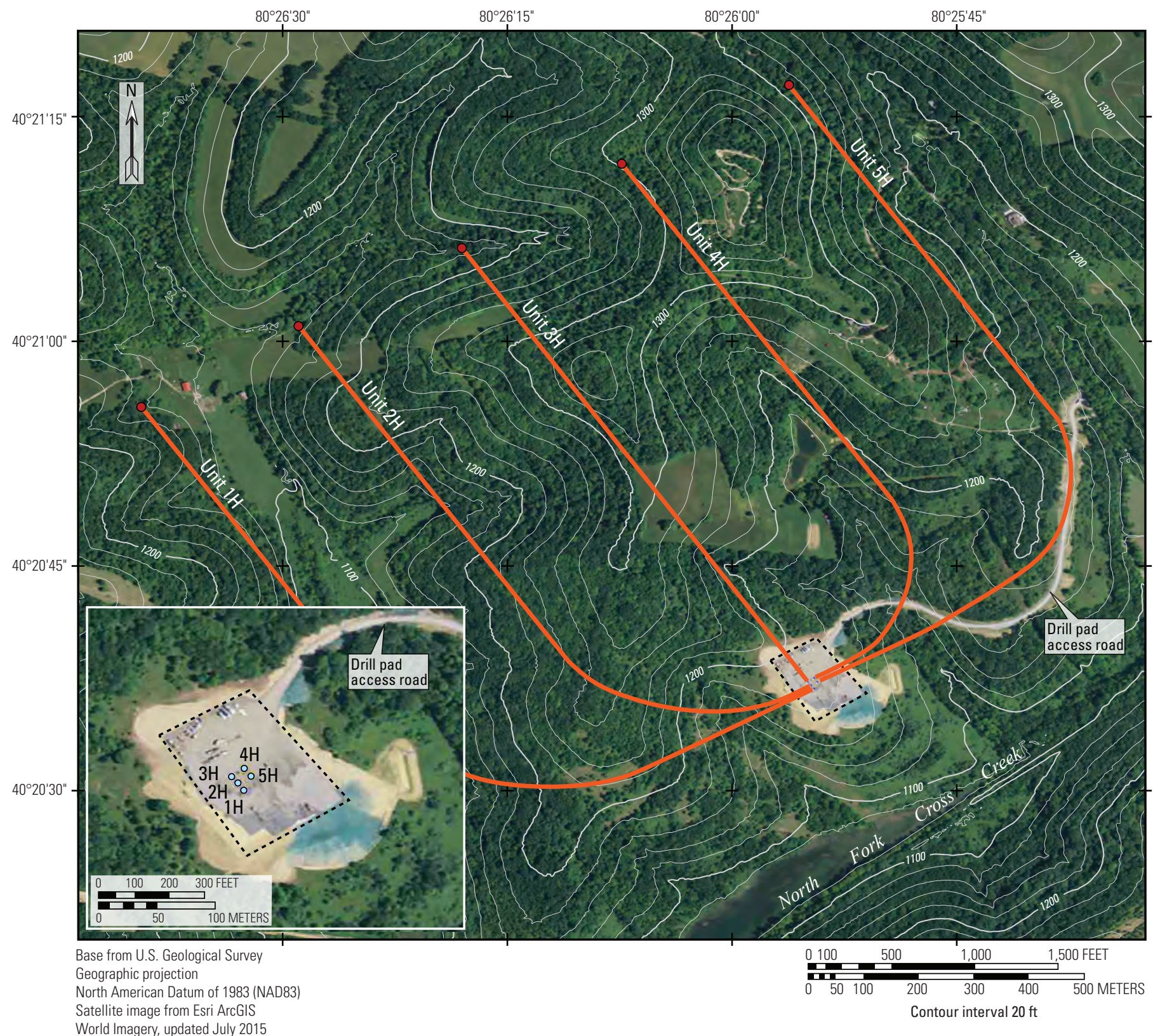

\section{EXPLANATION}

Approximate surface trace of deviated subsurface borehole legs

.... - Drill pad working area, approximately 3.0 acres

○ Well head locations

- Borehole terminations, given as surface locations

Figure 4. Overview and close-up satellite imagery showing the access road, drill pad working area, and proposed borehole leg traces of the five wells (Unit " $1 \mathrm{H}$ " to Unit " $5 \mathrm{H}$ ") at the RR-MCC drill site. The inset shows the drill pad working area and the well head locations of the five wells. Imagery is postdrilling and has been overlain with 20-ft-contour-interval topography. The borehole termination of the most direct borehole leg to the drill pad (well "Unit 3H"), extends approximately 1.0 kilometers northwestward. Satellite image from Esri ArcGIS World Imagery, 1-meter resolution (see table 4 for links to online source). Note that the abbreviation "RR-MCC" in the drill site name is short for "Range Resources MCC Partners L.P. Units 1-5H." Additional abbreviation: ft, feet. 


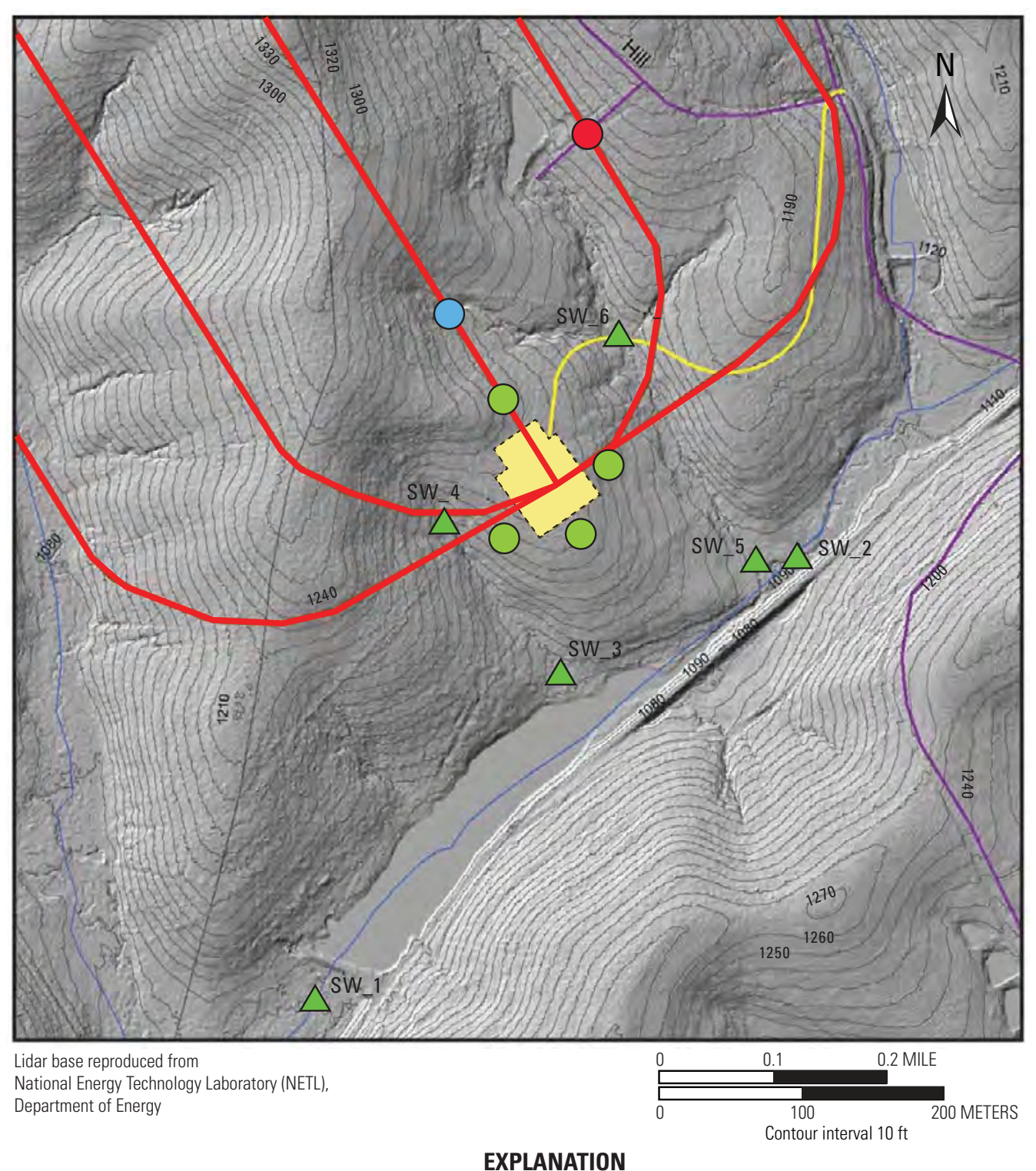

EXPLANATION

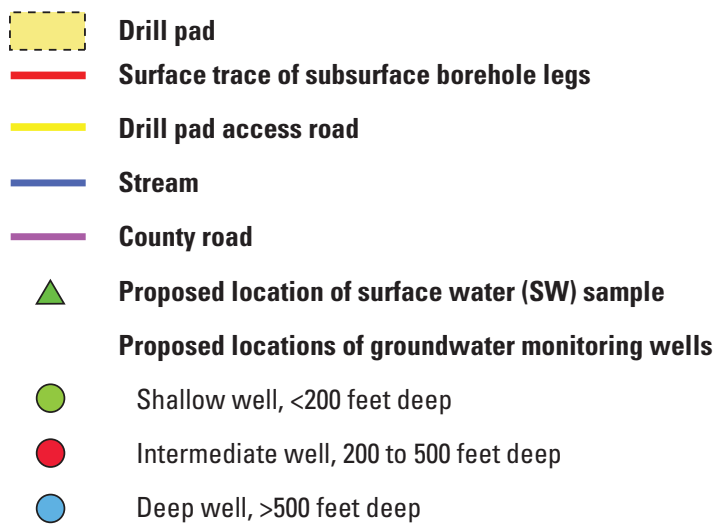

Figure 5. Map showing the proposed locations of the shallow, intermediate, and deep groundwater monitoring wells. Blue and red circles are possible locations for deep and intermediate groundwater monitoring wells to be drilled over a laterally directed borehole leg (red lines). Green circles are possible sites for shallow groundwater monitoring wells located around the drill pad. Green triangles are proposed locations of surface water stream samples. Image is reproduced from the Quality Assurance Project Plan (QAPP), as originally generated by National Energy Technology Laboratory (NETL) Marcellus Shale Project, which shows the proposed predrilling borehole legs. See figures 3 and 4 for approximate latitude and longitude coordinates for the RR-MCC drill site. Abbreviation: ft, feet. 


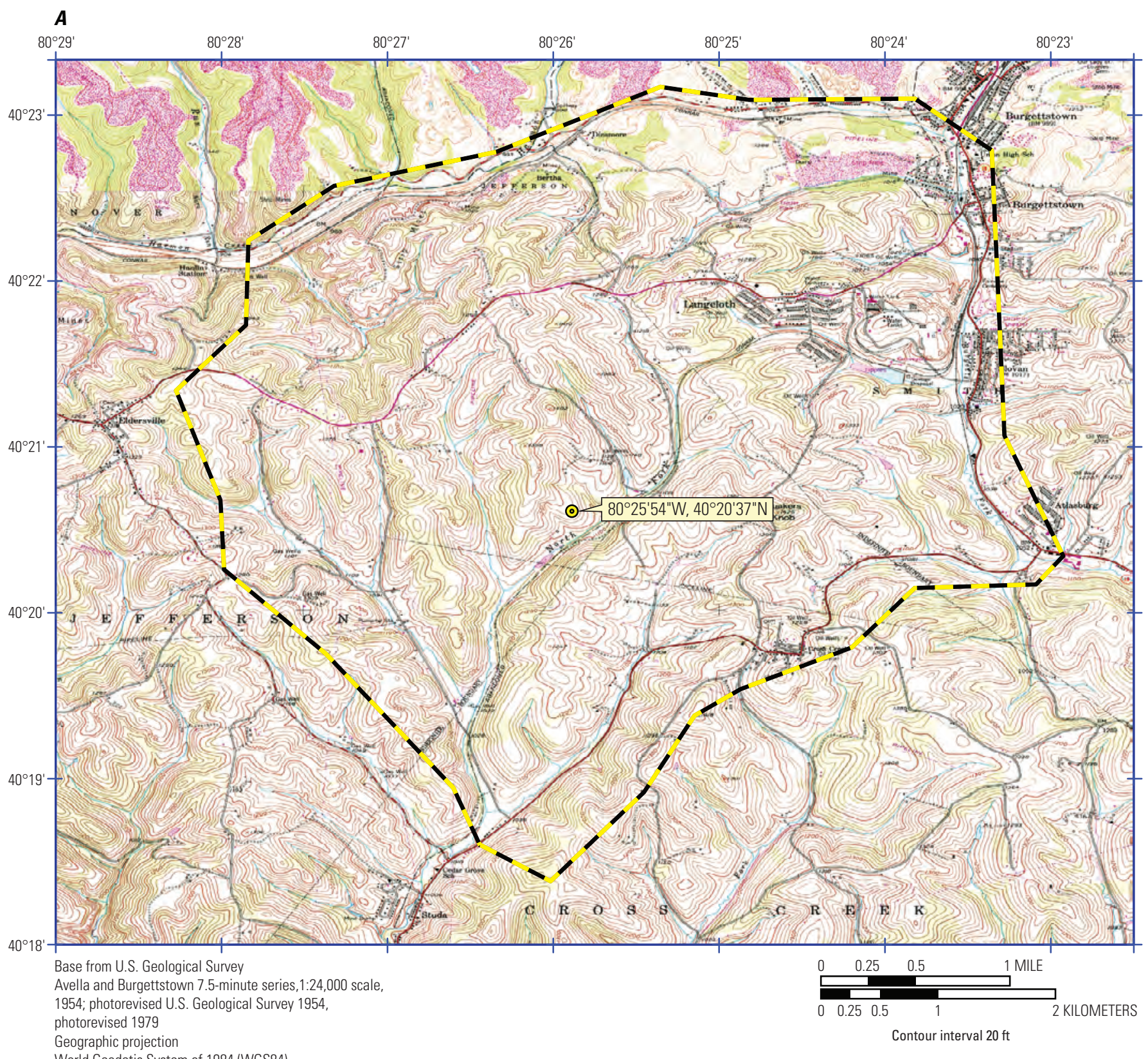

World Geodetic System of 1984 (WGS84)

National Geodetic Vertical Datum of 1929 (NGVD 1929)

EXPLANATION

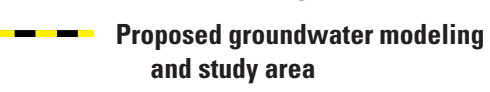

$\odot \quad$ RR-MCC drill site location

Figure 6. Maps showing the boundary of the groundwater modeling and study area. A, Proposed boundary of the groundwater modeling and study area (enclosed by black and yellow dashed line) shown on the U.S. Geological Survey Avella and Burgettstown 7.5-minute topographic map. $B$, Digitized boundary of the groundwater modeling and study area (enclosed by black and yellow dashed line) overlain on the 20 -ft-contour-interval topography (generated from 3.2-minute digital elevation model (DEM)) and watershed boundaries. The latitude-longitude coordinates for the RR-MCC drill site location is shown in A. Watershed boundary data are from PASDA (see table 4 for online link). Note that the abbreviation "RR-MCC" in the drill site name is short for "Range Resources MCC Partners L.P. Units 1-5H." Additional abbreviations: ft, feet; PASDA, Pennsylvania Spatial Data Access. 


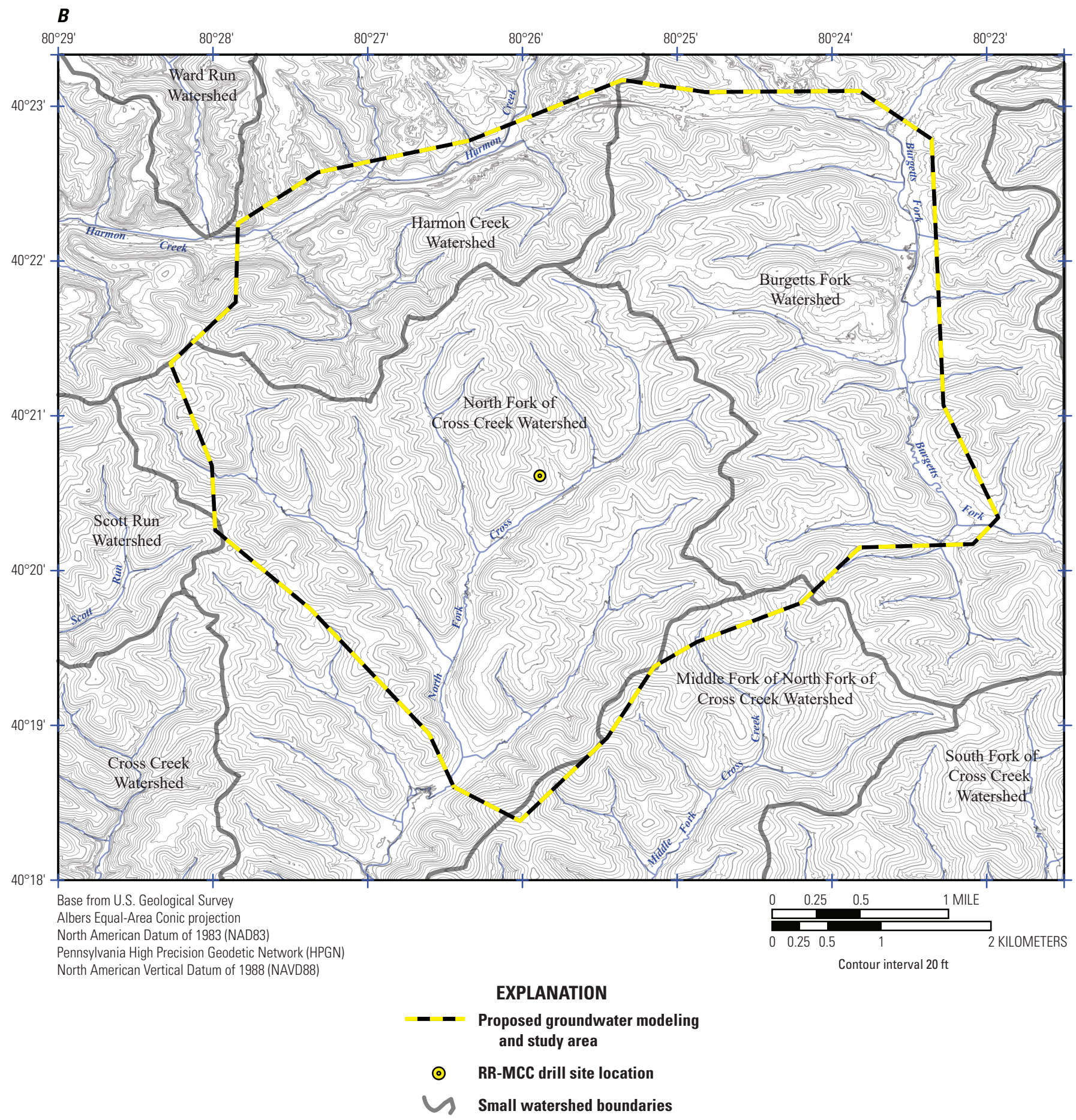

Figure 6. Continued. 


\section{Proposed Geologic Framework Study}

A refined site-specific geologic framework is expected to provide a more comprehensive understanding of the geologic parameters that may affect (1) groundwater movement and boundary conditions within the groundwater model area, (2) the siting of groundwater monitoring wells, (3) the infiltration of surface water as both direct precipitation and runoff (streams, ponds), and (4) the chemistry groundwater samples. Framework geologic studies, based on both existing literature and field investigations, are expected to include mapping of stratigraphic units and lithologic descriptions; these principally providing information on primary rock porosity and water chemistry, as well as bedrock discontinuity analysis and weathering that affects secondary rock porosity.

In support of the groundwater flow model, the EGPSC of the USGS agreed to develop a site-specific geologic framework study to support input parameters for a groundwater model. The site-specific geology is based on the best available large-scale, or most detailed, geologic map coverage of the model area. Geologic parameters of the site-specific study include:

1. Areal extent of surface and near-surface bedrock geology.

2. Subsurface bedrock geology to a depth of approximately $500 \mathrm{ft}$; a depth greater than the total local relief.

3. Distribution and expected thickness of unconsolidated surficial materials.

4. Lithologic descriptions and thicknesses of bedrock units.

5. Geologic structure.

6. Fracture and bedding plane discontinuity analysis.

7. Fracture and fault lineament analysis.

Being located in the Dunkard basin of the Alleghany Plateau of southwestern Pennsylvania, the study area has seen a long history of energy resource exploitation. Therefore, it is important to delimit the location of surface and subsurface coal mines, the latter commonly being abandoned flooded mines of the Pittsburgh coal bed. Additionally, the region has seen extensive pre-unconventional, deep Marcellus drilling for oil and gas resources. Therefore, additional parameters to the site-specific study include:

1. The location and extent of surface and subsurface coal mines.

2. The location of preexisting oil and gas wells.

All data derived from both literature and field work will be digitized and compiled into a geospatial format (GIS) that can be imported into a 3D groundwater modeling program.

\section{Objectives of Geologic Framework Study}

1. Geologic framework information is needed to produce a more accurate groundwater model as the characteristics of the geologic units affect movement of water in the aquifers and define geologic boundary conditions for the model.

2. Compile 3D geologic framework (stratigraphic and structural), conduct geologic site characterization where test wells are being installed, and analyze appropriate areas using remote sensing techniques to identify fracture traces.

3. Determine geologic controls on groundwater movement and storage, rock-water chemistry and interactions, and surface-water/groundwater interactions in concert with the hydrogeologists.

4. Provide fracture analysis of surface rocks based on remote sensing together with field inspection and scan-line analysis for possible controls on surfacewater infiltration, groundwater movement, and aquifer characteristics.

5. Map the stratigraphic units in the study area to determine the rock properties that are important for groundwater movement and chemistry, and determine how they differ in transporting or confining water.

\section{Background Geologic Information}

Generalized and detailed geology of this part of Washington County is provided by (1) Griswold and Munn (1907) in their description of the Steubenville, Burgettstown, and Claysville 15-minute quadrangles, (2) Shaw and Munn (1911) in their description of the Burgettstown and Carnegie 15-minute quadrangles, (3) Schweinfurth's (1976) detailed 1:24,000-scale bedrock geologic mapping of the Avella 7.5-minute quadrangle with lithologic descriptions, and (4) Harper and Laughrey (1987) in their treatment of the geology of the oil and gas fields of southwestern Pennsylvania. Hydrologic reports by Newport (1973) and Williams and others (1993) also provide a more generalized geology of Washington County. For the proposed RR-MCC groundwater modeling and case study project, the work of Schweinfurth (1976) provided the larger part of the stratigraphic framework and lithologic descriptions of the surface and near-surface geology and structural trends (fig. 7).

The surface and near-surface bedrock section in Washington County consists of sedimentary rocks of the Pennsylvanian-age Conemaugh and overlying Monongahela Groups and the Permian age Dunkard Group (fig. 8). Together, 
lithologies of these units consist of as much as $1,025 \mathrm{ft}$ of sandstone, siltstone, limestone, mudstone, and shale with lesser amounts of economic and noneconomic coal beds that were deposited in a vertically, somewhat repeated, cyclical succession. The distribution of lithologies within these units commonly exhibits a greater degree of vertical heterogeneity while they tend to be more homogeneous and persistent laterally. All of these groups are exposed in the surface section within the selected area of geologic coverage (AGC) of the RR-MCC drill site study area.

Older, unexposed bedrock units, which will likely be encounter in the deeper groundwater monitoring wells and that are also included in the groundwater model, include sedimentary rocks of the Pennsylvanian Allegheny Group (300-400 ft thick) and the underlying Pottsville Group (200-300 ft thick). These units, like those of the exposed section, also consist of sandstone, siltstone, claystone, mudstone, and shale, with lesser amounts of limestone and coal beds that were also deposited in a vertically cyclical succession. Like the exposed section, the lithologies of these units also commonly exhibit a greater degree of vertical heterogeneity, while laterally they tend to be more homogeneous and persistent.

Disconformably underlying the Pennsylvanian-age rocks, which are not likely to be encountered by deeper groundwater monitoring wells nor included in the groundwater model, is a clastic succession largely consisting of sandstone, siltstone, mudstone, and shale of Mississippian age (Harper and Laughrey, 1987). The Mississippian section in southwestern Pennsylvania is approximately $450 \mathrm{ft}(135 \mathrm{~m})$ thick. A prominent carbonate unit that occurs at or near the top of the Mississippian, the Greenbrier Limestone, is only known to occur south of Washington County, Pennsylvania; however, a near equivalent age, highly sandy limestone to calcareous sandstone, called the Loyalhanna Limestone Member of the Mauch Chunk Formation, extends northward into west-central Pennsylvania.

The following section provides lithologic descriptions of all lithostratigraphic units occurring in the Avella 7.5-minute quadrangle as mapped by Schweinfurth (1976). These abbreviated lithologic descriptions closely follow those provided by Schweinfurth (1976) that he includes with an idealized stratigraphic column on the map sheet of his report; his full descriptions of each lithostratigraphic unit are provided in appendix A of this report. The seven units that occur in the quadrangle include, in ascending order, the Glenshaw Formation, Casselman Formation, Pittsburgh Formation, Uniontown Formation, Waynesburg Formation, Washington Formation, and the Greene Formation.

These stratigraphic units, with the exception of the Glenshaw Formation, are exposed at the surface within the provisional groundwater modeling and study area. And, by consequence of the near flat-lying geologic structure, these units provide the subsurface geology that occurs within the local topographic relief of the model area. For this reason, lithologic descriptions of these units are provided in order to facilitate modelers in their selection of potential hydrostratigraphic units, either as a discrete unit or as grouped units, as inputs into the groundwater model. Although the provisional surface boundaries of the model area had been selected prior to the cancellation of the proposed RR-MCC cooperative study, no depth below the lowest elevation of local relief had been established in order to constrain the lower boundary of the model. For this reason, no descriptions of the older unexposed subsurface units of the Pennsylvanian Allegheny and Pottsville Groups and the Mississippian Mauch Chunk Formation (in descending order), were provided at the time of the study cancellation. Had the depth of the model's lower boundary been established, it was intended to provide lithologic descriptions of potentially involved bedrock units to the selected depth.

\section{Conemaugh Group}

\section{Glenshaw Formation}

Exposures of the Conemaugh Group in the Avella 7.5-minute quadrangle (Schweinfurth, 1976) include the Glenshaw Formation and overlying Casselman Formation. Only the upper part of the Glenshaw Formation (a partial thickness of approximately $100 \mathrm{ft}(30.5 \mathrm{~m})$ ) is exposed in the valley bottom of Harmon Creek, found in the northwestern corner of the quadrangle. Here, the gentle 1 to 2 degree, north-northwest upward-dipping stratigraphic succession has brought this oldest unit closer to the surface where it is exposed within the more deeply incised drainages of Harmon Creek and its tributaries. Within the selected boundaries of the AGC the Glenshaw Formation only occurs in the subsurface. The closest exposures of the Glenshaw Formation to the AGC are approximately located as near as $300 \mathrm{ft}(91 \mathrm{~m})$ due west of the western boundary of the AGC, along Harmon Creek. The lithology of the Glenshaw Formation in the Avella 7.5-minute quadrangle mainly consists of mudstone that is interbedded with both continuous and discontinuous thin to medium beds of siltstone and sandstone that are micaceous and argillaceous (Schweinfurth, 1976; see appendix A). The top of the Glenshaw Formation is marked by the regionally widespread, transgressive Ames Limestone Member. In the Avella quadrangle, the Ames is a laterally persistent, $3-\mathrm{ft}$ $(0.9 \mathrm{~m})$-thick fossiliferous limestone that is dark gray and thin to medium bedded. 


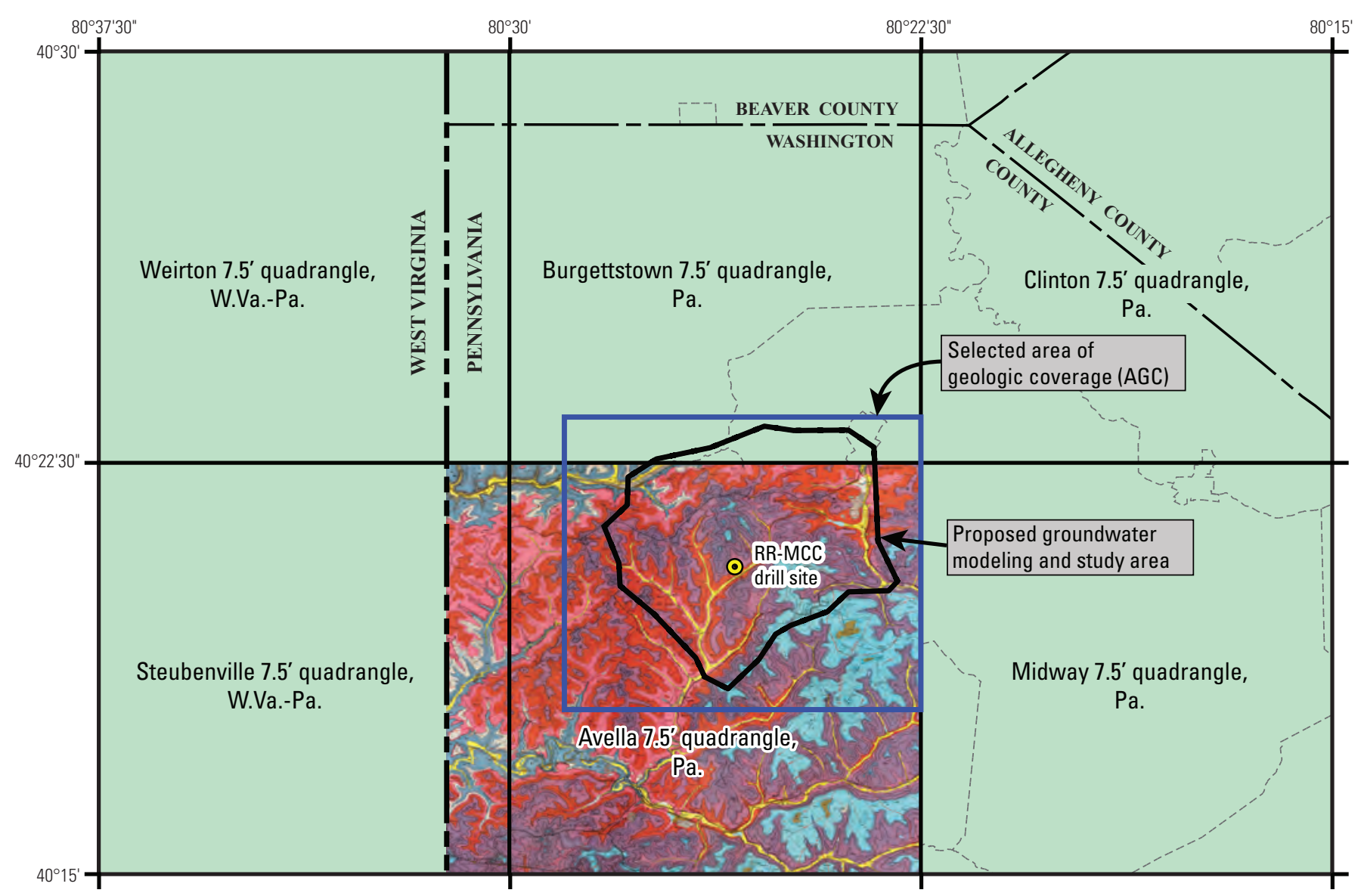

Figure 7. Map showing the area of the proposed groundwater modeling and study area (enclosed by black and yellow dashed line) and the area of geologic coverage (AGC) (inside blue box) overlain on the best available 1:24,000-scale geologic map of the Avella 7.5-minute quadrangle by Schweinfurth (1976). Adjacent quadrangle names are also shown. No published geologic map data at 1:24,000scale are available for the northernmost part of the proposed groundwater modeling and study area within the Burgettstown 7.5-minute quadrangle. The yellow circle is the location of the RR-MCC drill site. Note that the abbreviation "RR-MCC" in the drill site name is short for “Range Resources MCC Partners L.P. Units 1-5H.” Additional abbreviations: Pa., Pennsylvania; W. Va., West Virginia. 


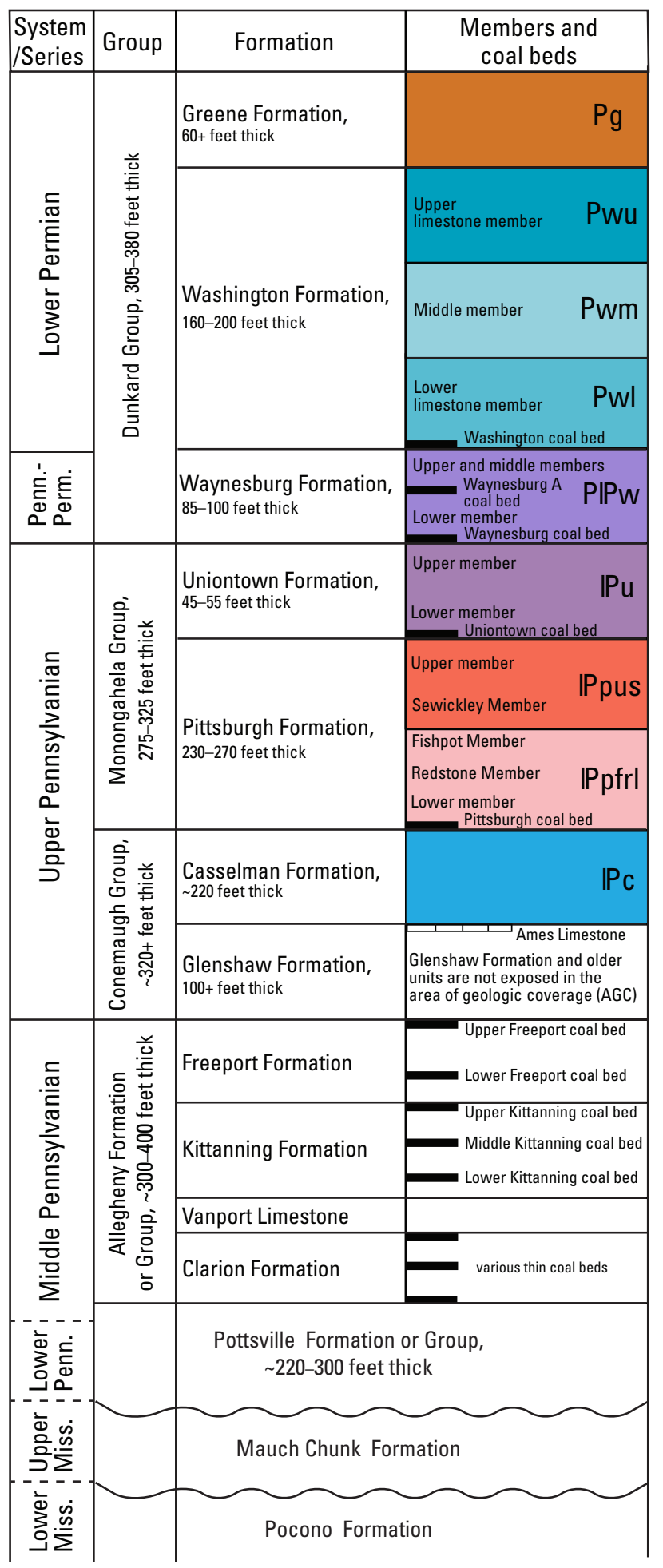

Figure 8. Idealized stratigraphic column of the surface and subsurface Mississippian, Pennsylvanian, and Permian age formations of Washington County, Pennsylvania. Colored stratigraphic units in the column are exposed at the surface within the area of geologic coverage (AGC). Unit colors and symbols in the stratigraphic column correspond to the map and cross-section colors and symbols in figures $10 \mathrm{~A}$ and $10 \mathrm{~B}$. Wavy lines represent unconformities; dashed lines represent uncertainty. Only coal beds occurring in the AGC are shown. Abbreviations: Miss., Mississippian; Penn., Pennsylvanian; Perm., Permian. 


\section{Casselman Formation}

Complete to partial exposures of the Casselman Formation occur in the updip sections in the northwestern and western areas of the Avella 7.5-minute quadrangle. More specifically, exposures of the these older strata are congruent with the more deeply incised valleys and tributaries of Harmon Creek to the northwest, Scott Run to the west, and Cross Creek to the south-southwest. Partial exposures of the upper part, and perhaps the middle part, of the Casselman Formation only occur within the northwest corner of the AGC, where it forms near-flat-lying exposures along the opposing lower valley walls of Harmon Creek. Other than this location, the full thickness of the Casselman Formation underlies the remaining area of the AGC. The expected extent of the Casselman Formation within the AGC is shown in figure 9.

In the Avella 7.5-minute quadrangle, the Casselman Formation is approximately $220 \mathrm{ft}(67 \mathrm{~m})$ thick (Schweinfurth, 1976). The Casselman Formation can broadly be divided into three subequal parts. The lower 60 to $70 \mathrm{ft}(18-21 \mathrm{~m})$ consists of mudstone and claystone that is interbedded with thin to medium beds of siltstone and fine- to medium-grained sandstone. The middle $70 \mathrm{ft}(21 \mathrm{~m})$ is medium to massively bedded, locally crossbedded, fine- to coarse-grained sandstone with some shale partings. The upper part is 60 to $70 \mathrm{ft}$ (18-21 $\mathrm{m}$ ) thick and consists of mudstone and claystone with thin to medium interbeds of siltstone and fine- to medium-grained sandstone; the upper part is similar to the lower part. Unlike the lower part, the upper part has two sequences of limestone, the lower sequence being 0 to $7 \mathrm{ft}(0-2 \mathrm{~m})$ thick and the upper sequence being 0 to $10 \mathrm{ft}(0-3 \mathrm{~m})$ thick that are separated by a 5- to 7-ft (1.5-2 m)-thick sequence of fine-grained sandstone; these units occur close to the top of the formation.

\section{Monongahela Group}

The Monongahela Group consists of the Pittsburgh Formation, which is subdivided into five members, and the overlying Uniontown Formation that is subdivided into a lower and upper member (Schweinfurth, 1976). The five members of the Pittsburgh Formation include, in ascending order, (1) the lower member, predominantly consisting of clastics and the economic Pittsburgh coal bed at the base; (2) the Redstone Member, consisting mostly of carbonates; (3) the Fishpot Member, consisting entirely of clastics; (4) the Sewickley Member that is largely represented by carbonates of the Benwood limestone bed; and (5) the upper member that consists of four repetitive couplets, each couplet having a lower clastic and upper carbonate part, with the limestone parts informally named a, b, c, and d in ascending order.

For mapping purposes, Schweinfurth (1976) subdivided the Pittsburgh Formation into two map units (figs. 8 and 10). One map unit combines the three lowest members: the lower member, the Redstone Member, and the Fishpot Member, a succession that is largely dominated by siliciclastics rather than carbonates. The other map unit combines the two uppermost members: the Sewickley Member and the upper member, a succession that is largely dominated by carbonates rather than siliciclastics. Following Schweinfurth (1976), both map units of the Pittsburgh Formation were digitized, as the more clastic dominant lithology of the lower map unit as opposed to the carbonate dominate lithology of the upper map unit; digitizing the two units as separate lithologies would likely provide two distinct hydrostratigraphic units of differing input parameters to the groundwater model.

\section{Pittsburgh Formation}

The Pittsburgh Formation in the Avella 7.5-minute quadrangle varies from 230 to $270 \mathrm{ft}(70-82 \mathrm{~m})$ in thickness; no individual thicknesses of its five members were reported by Schweinfurth (1976). In the updip sections of the western, central, and northeastern areas of the quadrangle, where the Pittsburgh Formation is closer to the surface, it comprises a large part of the surface exposure. This is because its near flat-lying thickness of 230 to $270 \mathrm{ft}$ is either equal to or nearly exceeds the local relief of 200 to $300 \mathrm{ft}$ of most hills. It is absent due to erosion along Harmon Creek to the northwest and Burgetts Fork to the northeast. In the downdip sections of the eastern, southeastern, and southern parts of the quadrangle, surface exposures of the Pittsburgh Formation are areally limited, as it principally occurs in the subsurface. Here, exposures are found along the lower slopes and bottoms of valleys of the more deeply incised major drainages and their tributaries, such as Cross Creek, South Fork, and Haynan Creek. The expected extent of the Pittsburgh Formation in the AGC, both as a partial thickness (where exposed) and a full thickness (where in the subsurface) is shown in figure 11.

For the lower member, no thickness was reported by Schweinfurth (1976). However, because he shows it to be about one-fifth of the total relative thickness of the Pittsburgh Formation on the diagrammatic stratigraphic column of the map sheet, we estimate it to be approximately 46 to $54 \mathrm{ft}$ (14-16 m) thick. The lower member consists of interbedded limestone, mudstone, and claystone that, in places, may be partly to entirely incised by massive channel sandstones. The economic Pittsburgh coal bed is as much as 58 inches $(1.5 \mathrm{~m})$ thick in the Avella 7.5-minute quadrangle, and occurs at the base of the lower member (Schweinfurth, 1976). Limestones exhibit a hackly weathering fracture pattern, are very fine grained, very argillaceous, and occur in beds as little as a few inches $(5 \mathrm{~cm})$ to as much as $3 \mathrm{ft}(0.9 \mathrm{~m})$ thick. Also, they are occasionally laminated, possibly suggesting a freshwater algal origin, and occasionally have primary depositional shrinkage cracks and solution features. Mudstone and claystone are poorly bedded, micaceous, and locally calcareous.

For the Redstone Member, Schweinfurth (1976) provides no discussion of its thickness; however, his graphic stratigraphic column shows it to be slightly more than one-fifth 
the total relative thickness of the Pittsburgh Formation, and therefore the thickness is estimated to be about 52 to $61 \mathrm{ft}$ (16-18.5 m). It consists of interbedded mudstone, limestone, claystone, and shale. As with the underlying lower member, the limestones also exhibit a hackly weathering fracture pattern, are very fine grained, very argillaceous, occur in beds as little as a few inches $(5 \mathrm{~cm})$ to as much as $3 \mathrm{ft}(0.9 \mathrm{~m})$ thick, are occasionally laminated (possible suggesting freshwater algal origin), and occasionally have shrinkage cracks and solution features. Mudstone and claystone are also similar to the lower member, being poorly bedded, micaceous, and locally calcareous. A 5- to 17-ft (1.5-5 m)-thick sequence of limestone is commonly present at the top of the member.

The Fishpot Member is estimated to be 29 to $34 \mathrm{ft}$ (9-10 m) thick; again, this is based on the graphic stratigraphic column by Schweinfurth (1976) that shows the Fishpot Member to be about one-eighth of the total relative thickness of the Pittsburgh Formation. The member is entirely clastic, predominantly mudstone that is interbedded with thin siltstone beds and very fine grained sandstone. Mudstone and claystone lithologies are similar to the lower member, being poorly bedded, micaceous, and locally calcareous. Massive sandstone that is up to $15 \mathrm{ft}$ ( $4.5 \mathrm{~m})$ thick, fine to medium grained, argillaceous, friable, thin to massive bedded, and generally crossbedded, can be expected locally.

The Sewickley Member is a succession of fine-grained limestone estimated to be 46 to $54 \mathrm{ft}(14-16 \mathrm{~m})$ thick. Similar to the other members of the Pittsburgh Formation, the thickness is estimated from the graphic stratigraphic column on the map sheet of Schweinfurth (1976), which shows this member to be approximately one-fifth of the total relative thickness of the Pittsburgh Formation. The limestone lithology is similar to that of the previously described limestone lithologies of the lower member and Redstone Member; it exhibits a hackly weathering fracture pattern, it is very fine grained, very argillaceous, occurs in beds as little as a few inches $(5 \mathrm{~cm})$ to as much as $3 \mathrm{ft}(0.9 \mathrm{~m})$ thick, is occasionally laminated (possible suggesting freshwater algal origin), and occasionally it has shrinkage cracks and solution features. The lower part of the member generally consists of 1 to $2 \mathrm{ft}(0.3-0.6 \mathrm{~m})$ of poorly bedded calcareous mudstone and claystone (Schweinfurth, 1976).

The upper member of the Pittsburgh Formation is estimated to be 62 to $73 \mathrm{ft}$ (19-22.5 m) thick; also based on the stratigraphic column in Schweinfurth (1976) in which he shows this member to be slightly greater that one-fourth of the total relative thickness of the Pittsburgh Formation. As illustrated and described by Schweinfurth (1976), the upper member consists of four vertically successive couplets of subequal thicknesses; each couplet consists of a lower part of very fine to fine-grained clastics and an upper part of carbonate. The upper limestone of the couplets vary from 5 to $15 \mathrm{ft}(1.5-4.5 \mathrm{~m})$ in thickness and are referred to as "limestone a," "limestone b," "limestone c," and "limestone d" in ascending order (Schweinfurth, 1976). These limestones are generally vertically discrete and laterally persistent; although locally, limestones "a" and "b" together as well as limestones "c" and "d" together may be vertically continuous. The limestone is reported to be very fine grained, very argillaceous, occurs in beds that are approximately 2 inches to $3 \mathrm{ft}(5 \mathrm{~cm}-1 \mathrm{~m})$ thick, and exhibits primary sedimentary brecciation and laminations of possible algal origin. The clastic part of the couplet separating limestones $\mathrm{a}, \mathrm{b}, \mathrm{c}$, and $\mathrm{d}$ is predominantly mudstone and shale that is poorly bedded, micaceous, and locally calcareous with local calcareous siltstone. Occurring at the base of the upper member is a localized occurrence of fine-grained sandstone that is thin to medium bedded, locally calcareous, commonly well indurated, and up to $3 \mathrm{ft}(1 \mathrm{~m})$ thick. 


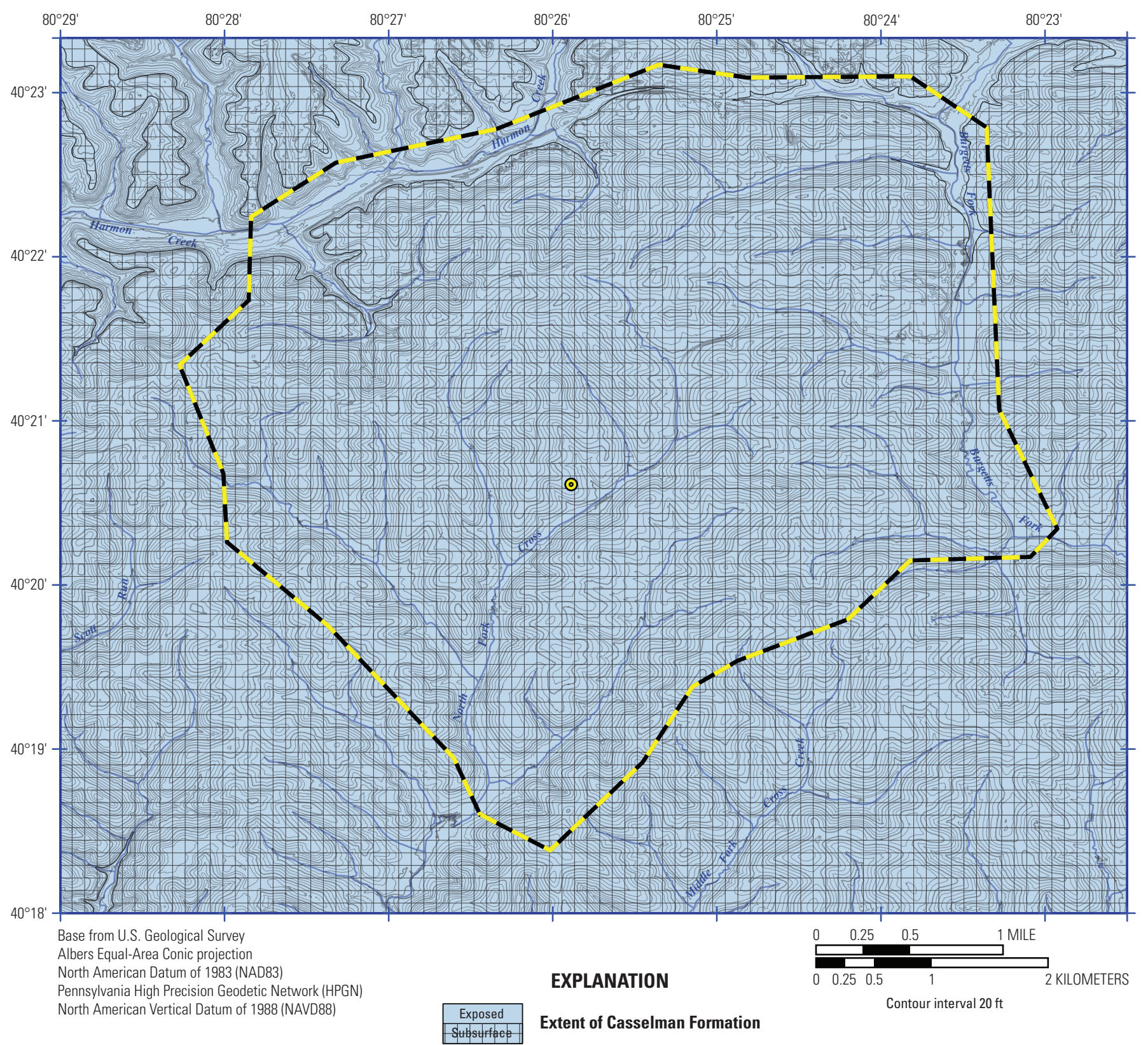

- - Proposed groundwater modeling and study area

Figure 9. Map showing the distribution of the Casselman Formation as both surface (exposed) and subsurface occurrences in the larger area of geologic coverage (AGC) (entire map) and the proposed groundwater modeling and study area (enclosed by black and yellow dashed line). Where not hachured, the Casselman Formation occurs as surface exposures; where hachured, the Casselman Formation is present in the subsurface overlain by younger units. Note that the abbreviation "RR-MCC" in the drill site name is short for “Range Resources MCC Partners L.P. Units 1-5H." Abbreviation: ft, feet. 


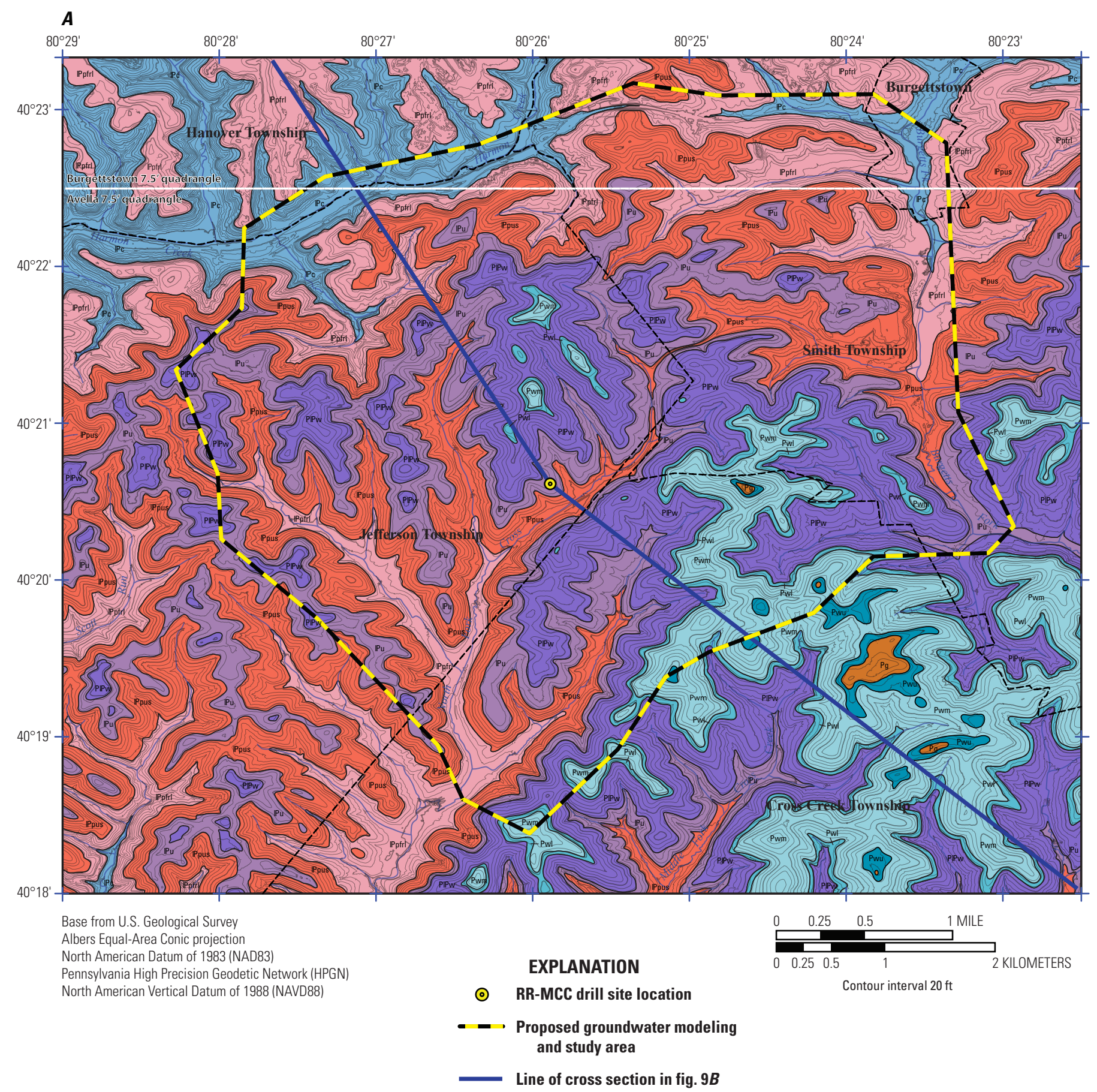

Figure 10. Bedrock geologic map and cross section within the area of geologic coverage (AGC). A, Bedrock geologic map of the AGC that is largely digitized from Schweinfurth (1976). $B$, Generalized northwest (NW) to southeast (SE) cross section (blue line in A). Stratigraphic unit abbreviations: Pc, Casselman Formation; Ppfrl, Pittsburgh Formation (Fishpot Member, Redstone Limestone Member, lower member); Ppus, Pittsburgh Formation (upper member, Sewickley Member); Pu, Uniontown Formation; PPw, Waynesburg Formation; Pwl, Washington Formation (lower limestone member); Pwm, Washington Formation (middle member); Pwu, Washington Formation (upper limestone member); Pg, Greene Formation. The three members of the Washington Formation (Pwl, Pwm, and Pwu) are shown as one unit on the cross section. See figure 8 for mapped coal bed names. Note that the abbreviation "RR-MCC" in the drill site name is short for “Range Resources MCC Partners L.P. Units 1-5H." Additional abbreviations: ft, feet; SL, sea level. 


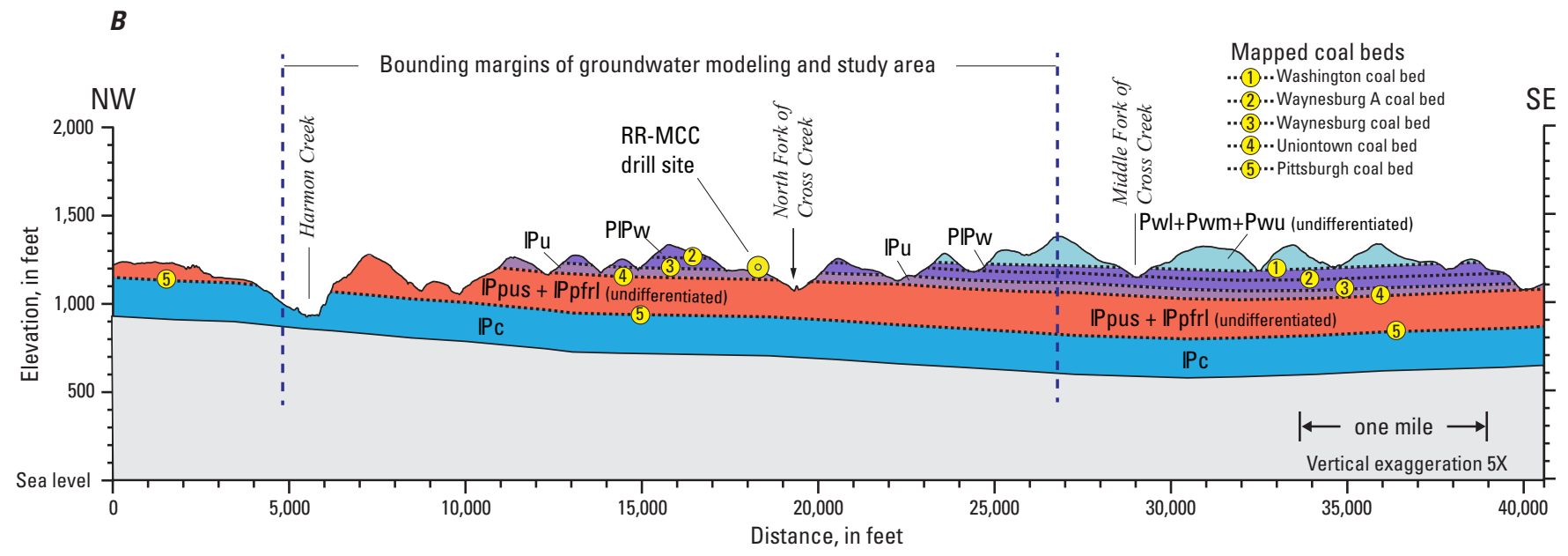

Figure 10. Continued. 


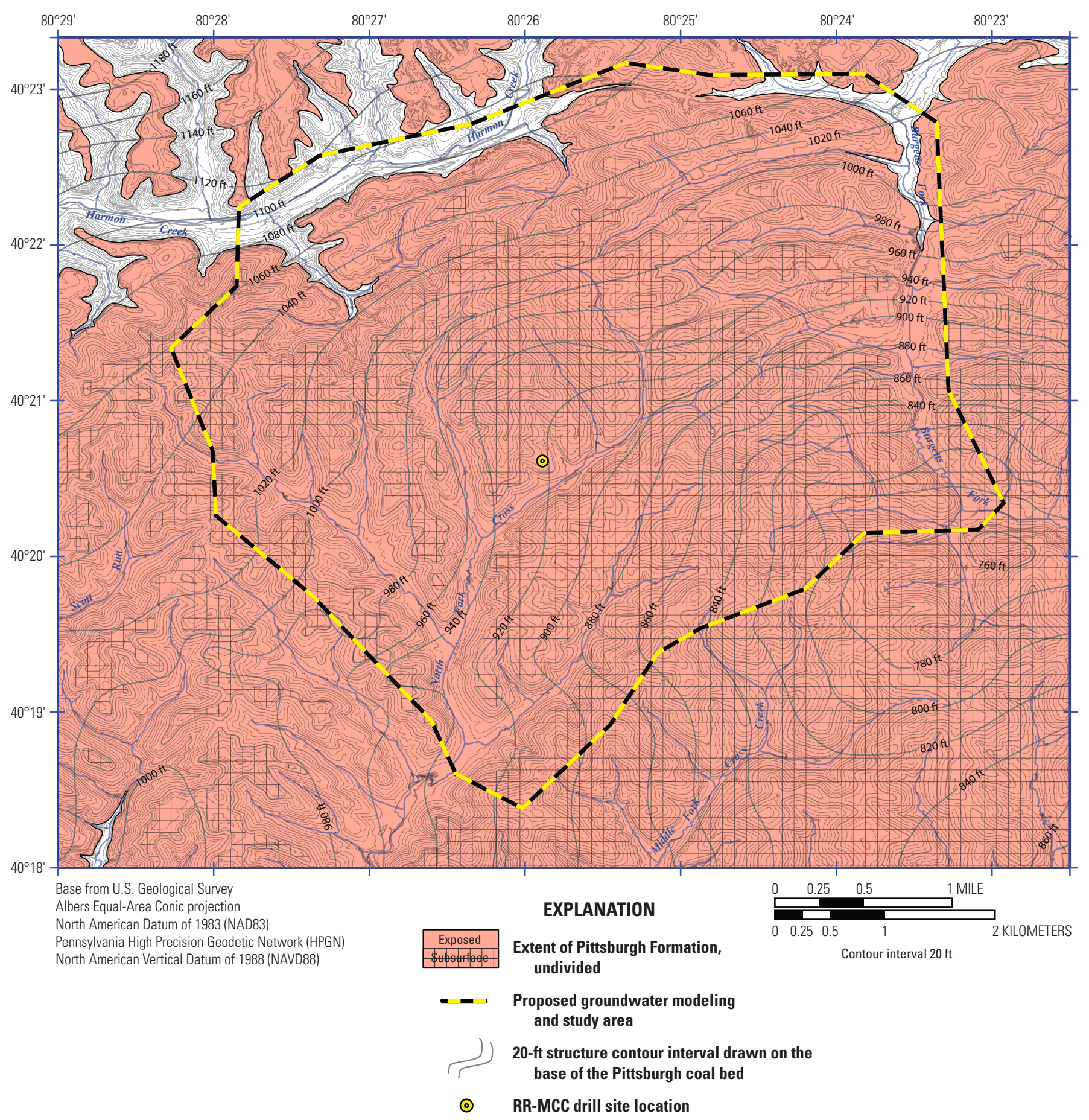

Figure 11. Map showing the distribution of the Pittsburgh Formation as both surface (exposed) and subsurface occurrences in the larger area of geologic coverage (AGC) (entire map) and the proposed groundwater modeling and study area (enclosed by black and yellow dashed line). Where not hachured, the Pittsburgh Formation occurs as surface exposures; where hachured, the Pittsburgh Formation is present in the subsurface overlain by younger units. The 20-ft structure contours shown are drawn on the basal Pittsburgh coal bed (see table 4 for link to online source used for structure contours). Note that the map does not divide the Pittsburgh Formation into the two map units as used by Schweinfurth (1976). Also note that the abbreviation "RR-MCC" in the drill site name is short for "Range Resources MCC Partners L.P. Units 1-5H." Additional abbreviation: ft, feet. 


\section{Uniontown Formation}

The Uniontown Formation in the Avella 7.5-minute quadrangle varies from 45 to $55 \mathrm{ft}(13.7-16.7 \mathrm{~m})$ in thickness and is divided into a lower member and upper member by Schweinfurth (1976). In the updip sections of the western, central, and north-central part of the quadrangle, surface exposures of the Uniontown Formation are very discontinuous. Here the Uniontown commonly occurs as erosional remnants, occurring as both small patches that cap isolated hill tops and as relatively continuous sinuous areas that cap and are congruent with higher ridgelines. In the downdip sections of the eastern, southeastern, and southern parts of the quadrangle the Uniontown largely occurs in the subsurface. Where exposed at the surface, this nearly flat-lying unit is generally present as a continuous, slope-contouring outcrop belt within the lower to middle slopes of most major drainages. The distribution of the Uniontown Formation within the AGC mainly follows as just described for the larger quadrangle area. The expected areal extent of the Uniontown Formation in the AGC, both as a partial thickness (where exposed) and as full thickness (in the subsurface), is shown in figure 12.

The Uniontown Formation is mainly a fine-grained clastic succession that principally consists of mudstone with lesser interbeds of siltstone and fine-grained sandstone and local massive sandstone. It is readily distinguishable from the underlying Sewickley and upper members of the Pittsburgh Formation, which are carbonate dominant. It is less readily distinguishable from the overlying lower member of the Waynesburg Formation, which is also a succession of more fine-grained clastic rocks. However, the presence of the 1- to 6-ft (0.3-2 m)-thick, locally economic Waynesburg coal bed at the base of the lower member of the Waynesburg Formation serves as a regional, laterally persistent marker between these formations.

Schweinfurth (1976) recognizes the lower member and upper member of the Uniontown Formation in the Avella 7.5-minute quadrangle, but similar to the five members of the Pittsburgh Formation, he does not report thickness estimates for the two Uniontown members; therefore, similarly we estimate the lower and upper member thicknesses based on the relative thicknesses shown on his stratigraphic column. The thickness of the lower member is estimated to be approximately 27 to $33 \mathrm{ft}$ $(8-10 \mathrm{~m})$ and the thickness of the upper member is estimated at $18-22 \mathrm{ft}(5.5-7 \mathrm{~m})$.

Both members have nearly identical lithologies, although some variations in lithology occurs locally. Common to both members, they principally consist of poorly bedded, locally calcareous mudstone with lesser interbeds of siltstone and fine-grained sandstone, and locally consist of massive sandstone. The massive sandstones of each member are fine to medium grained, thin to massive bedded, and crossbedded (likely channel sandstones), that may account for the full vertical thickness of the member, in places. The two members of the Uniontown differ in that the lower member, unlike the upper member, contains up to $5 \mathrm{ft}(1.5 \mathrm{~m})$ of laterally continuous limestone and marl at its top. This limestone is very fine grained, grades upward from being more to less argillaceous, and occurs in beds that are $1-3 \mathrm{ft}(0.3-0.9 \mathrm{~m})$ thick.

Also, each member has an informally named coal bed that occurs at its base; the "Uniontown coal bed" for the lower member and the "Little Waynesburg coal bed" for the upper member (Schweinfurth, 1976). The Uniontown coal bed, mapped as unit "u" by Schweinfurth (1976), is commonly less than $1 \mathrm{ft}(0.3 \mathrm{~m})$ thick. It consists of argillaceous, discontinuous coal that laterally grades into carbonaceous shale that is locally absent where it is erosionally incised and removed by the massive sandstone. The Little Waynesburg coal bed, mapped as unit "lwb" by Schweinfurth (1976), may locally reach thicknesses of up to $5 \mathrm{ft}(1.5 \mathrm{~m})$. It is also laterally discontinuous and is principally composed of carbonaceous shale with coal; the coal may be locally absent where it is also erosionally incised and removed by massive sandstone. Schweinfurth (1976) maps the presence of the Uniontown coal bed throughout the Avella 7.5-minute quadrangle and it is present throughout the smaller area of the AGC. The Little Waynesburg coal bed, however, is only mapped in the southeasternmost corner of the quadrangle and it is not present within the AGC.

\section{Waynesburg Formation}

The Waynesburg Formation in Washington County is divided into three informal members by Berryhill and Swanson (1962); a lower member dominated by sandstone, a middle member of mostly limestone, and an upper member dominated by siltstone-sandstone. In the Avella 7.5-minute quadrangle, Schweinfurth (1976) recognizes the lower sandstone member only, and the middle limestone and upper siltstone-sandstone members are combined (undivided) because the greater content of limestone in the latter member made it difficult to distinguish from the former member. The Waynesburg Formation in the Avella 7.5-minute quadrangle varies from 85 to $120 \mathrm{ft}(26-36 \mathrm{~m})$ in thickness. Like the underlying Uniontown Formation, surface exposures of the Waynesburg Formation in the updip sections of the western, central, and north-central part of the quadrangle are very discontinuous and commonly occur as erosional remnants; both as small isolated patches capping hill tops and as relatively continuous (but irregular), somewhat larger areas that cap and coincide with higher sinuous ridgelines. In the downdip sections of the eastern, southeastern, and southern parts of the quadrangle the Waynesburg largely occurs in the subsurface, but within the limits of the topographic relief. Where exposed at the surface, this flat-lying unit is generally present as a continuous, slope-contouring outcrop belt within the lower to middle slopes of all drainages. The distribution of the Waynesburg Formation within the smaller area of the AGC closely follows as is described for the larger quadrangle area. The expected areal extent of the Waynesburg Formation in the AGC, both as a partial thickness (where exposed) and a full thickness (where in the subsurface), is shown in figure 13. 
No thickness for the lower member was reported by Schweinfurth (1976), although his stratigraphic column showed it to be approximately 50 percent of the total thickness of the Waynesburg Formation. Therefore, the lower member is estimated to vary from 42.5 to $60 \mathrm{ft}(13-18 \mathrm{~m})$ in thickness. The lower member of the Waynesburg Formation principally consists of a succession of fine-grained siliciclastics that has three zones of lenticular limestone, and it may locally have massive sandstone in the lower part and an informally named basal coal bed referred to as the "Waynesburg coal bed." The fine-grained siliciclastics mainly consist of poorly bedded mudstone that is interbedded with siltstone and fine-grained sandstone. The lenticular limestone zones, in ascending order, include (1) a minor, laterally persistent $1-\mathrm{ft}(0.3 \mathrm{~m})$-thick zone that occurs 5-10 $\mathrm{ft}(1.5-3 \mathrm{~m})$ above the base, (2) a minor, less laterally persistent 3 -ft (1 m)-thick zone occurring near the middle of the member, and (3) a major, highly laterally persistent zone as much as $8 \mathrm{ft}(2.5 \mathrm{~m})$ thick occurring at the top of the member. These limestones are very fine grained, argillaceous, occasionally carbonaceous, and occur in beds from a few inches $(5 \mathrm{~cm})$ up to $2 \mathrm{ft}(0.5 \mathrm{~m})$ in thickness. The massive sandstone that locally occurs in the lower part of the member is fine to medium grained, thin to massive bedded, commonly crossbedded, and may reach a thickness of up to $25 \mathrm{ft}(7.5 \mathrm{~m})$. The Waynesburg coal bed that occurs at the base of the lower member is economically exploited locally in the Avella 7.5-minute quadrangle, with one subsurface mine being identified within the AGC (fig. 14). The coal bed can vary from 1 to $6 \mathrm{ft}(0.3-1.8 \mathrm{~m})$ in thickness and is generally argillaceous and interbedded with shale and clay. Schweinfurth (1976) mapped the Waynesburg coal bed (unit "wb" on his map) throughout the Avella 7.5-minute quadrangle. Structure contour map and crop line map coverage of the Waynesburg coal bed within the AGC were also produced by the Work Projects Administration (1935; project number 19666, sheet numbers 4, 5, 7, and 9). The presence of the Waynesburg coal bed at the base of the Waynesburg Formation also marks the contact with the underlying Uniontown Formation throughout the quadrangle and within the AGC.

Together, the undivided middle and upper members of the Waynesburg Formation are shown in the stratigraphic column of Schweinfurth (1976) to be approximately 50 percent of the total thickness of the Waynesburg Formation. These undivided members are estimated to vary from 42.5 to $60 \mathrm{ft}(13-18 \mathrm{~m})$ in thickness. The lithologies of these members represent a vertically heterogeneous succession of interbedded mudstone, shale, and limestone with numerous sandstones and several informally named coal beds. The shales are indicated to be fissile and micaceous, and the mudstones (as with other previously described mudstones) are poorly bedded, micaceous, may possess siderite nodules, and may be locally calcareous. Limestone is very fine grained, argillaceous to very argillaceous, locally siliceous, and occurs in beds varying from several inches $(5 \mathrm{~cm})$ to $3 \mathrm{ft}(0.9 \mathrm{~m})$ in thickness. Laterally noncontinuous sandstone beds occur at several stratigraphic levels within the undivided members. These sandstones vary between 3 to $5 \mathrm{ft}(0.9-1.5 \mathrm{~m})$ in thickness, are fine to medium grained, medium to massive bedded, locally crossbedded, vary from poorly to well indurated, and are micaceous and argillaceous.

The two identified coal beds that occur within the undivided middle and upper members of the Waynesburg Formation include the "Waynesburg A" and "Waynesburg B" coal beds. The Waynesburg A coal bed occurs at the base of the two undivided members and, with some uncertainty by Schweinfurth (1976), the Waynesburg B coal bed is placed approximately $25 \mathrm{ft}(7.5 \mathrm{~m})$ above the base. The Waynesburg A coal bed, mapped as unit "wb A" by Schweinfurth (1976), is laterally continuous, as much as $8 \mathrm{ft}(2.5 \mathrm{~m})$ thick, and is shown to occur throughout the Avella 7.5-minute quadrangle. The thinner Waynesburg B coal bed, mapped as unit "wb B" by Schweinfurth (1976), is only identified in the hill slopes of the southernmost and southwestern corner of the quadrangle and does not occur within the AGC. It was the intent of this author to digitize the occurrence of the Waynesburg A coal bed within the limits of the AGC for two main reasons. First, it would have provided a datum for distinguishing the lower member from the undivided middle and upper members of the Waynesburg Formation. Second, coal beds are commonly highly jointed by systematic fracture sets (face and butt cleats) that potentially serve as secondary porosity conduits for groundwater flow while associated underclays (weathering paleosols) act as impervious horizons, both deemed to be important inputs the groundwater flow model. However, the digitization of the Waynesburg A coal bed was not carried out due to the cancellation of the proposed cooperative RR-MCC study.

\section{Washington Formation}

In the Avella 7.5-minute quadrangle, the Washington Formation is principally a 160 - to $200-\mathrm{ft}$ (48-61 m)-thick succession of varying carbonate lithologies, containing some siliciclastics and lesser coal, that is divided into a lower limestone member, a middle member, and an upper limestone member (Schweinfurth, 1976). It is nearly exclusively found in the downdip sections of the eastern and southeastern parts of the Avella 7.5-minute quadrangle where it forms widespread, near flat-lying surface exposures. These exposures occur as both isolated patches capping high hill tops and as relatively continuous but irregular areas that coincide with and cap higher ridgelines. Elsewhere in the quadrangle the Washington Formation is absent, with the exception of small erosional remnants that cap small hilltops in the central and southwesternmost areas of the quadrangle. The Washington Formation only occurs in the subsurface in the southeastern part of the quadrangle, where it is overlain by small erosional remnants of the overlying, hill-capping Greene Formation. The distribution of the Washington Formation within the smaller area of the AGC principally follows as just described for the larger quadrangle. The expected areal extent of the Washington Formation in the AGC, both as a partial thickness 
(where exposed) and a full thickness (where in the subsurface), is shown in figure 15. At the time of the suspension of the cooperative RR-MCC study, the mapped contacts between the three members of the Washington Formation had been digitized.

Schweinfurth (1976) did not report thicknesses for the three members of the Washington Formation; however, based on his graphic stratigraphic column we estimate the lower limestone member being approximately 16 percent, the middle member approximately 70 percent, and the upper limestone member approximately 14 percent of the total relative thickness of the formation. Using this criterion within the Avella 7.5-minute quadrangle, the thickness of the lower limestone member varies from 25.6 to $32 \mathrm{ft}(8-10 \mathrm{~m})$, the thickness of the middle member varies from 112 to $140 \mathrm{ft}$ (34-43 m), and the thickness of the upper limestone member varies from 22.4 to $28 \mathrm{ft}(7-8.5 \mathrm{~m})$. Schweinfurth mapped the three members individually in the Avella 7.5-minute quadrangle, the lower limestone member was mapped as unit "Pwl," the middle member was mapped as unit "Pwm," and the upper limestone member was mapped as unit "Pwu." These three map units were digitized for the proposed RR-MCC cooperative study (figs. 8 and 15).

The 25.6- to $32-\mathrm{ft}(8-10 \mathrm{~m})$-thick lower limestone member consists of two vertically differing lithologies of unequal thickness. The first lithology that forms the lowermost part of the member consists of 5 to $8 \mathrm{ft}(1.5-2.5 \mathrm{~m})$ of coal and carbonaceous shale that is informally named the "Washington coal bed" (map unit "w" of Schweinfurth (1976)). The Washington coal bed principally consists of coal interbedded with clay, but laterally it may grade into carbonaceous shale that contains a persistent bed of coal as much as $2 \mathrm{ft}(0.6 \mathrm{~m})$ thick at the base. The second lithology that accounts for the remainder of the lower member is limestone. The limestone is very fine grained, argillaceous, siliceous to very siliceous, exhibits algal laminate structure, and occurs in beds from several inches $(5 \mathrm{~cm})$ to $2 \mathrm{ft}(0.6 \mathrm{~m})$ thick. Schweinfurth (1976) maps the Washington coal bed of the lower member as being present throughout the Avella 7.5-minute quadrangle.

The 112- to 140-ft (34-43 m)-thick middle member principally consists of argillaceous limestone that occurs as numerous successive sequences varying from 10 to $30 \mathrm{ft}$ (3-9 m) thick. These sequences are separated by (and may be interbedded with) thinner intervals of more finely grained siliciclastics. The upper part of the middle member becomes more clastic dominant. The limestones are argillaceous to very argillaceous, very fine grained, may be siliceous, and occur in beds from several inches $(5 \mathrm{~cm})$ to $3 \mathrm{ft}(0.9 \mathrm{~m})$ in thickness. The siliciclastics include mudstone interbedded with siltstone and several sandstone beds. The mudstone is poorly bedded, micaceous, and contains siderite in the form of small nodules. The sandstone is fine to medium grained, medium to massive bedded, locally crossbedded, poorly to well indurated, and occur as beds up to $5 \mathrm{ft}(1.5 \mathrm{~m})$ thick.

The upper limestone member is 22.4 to $28 \mathrm{ft}(7-8.5 \mathrm{~m})$ thick and is exclusively argillaceous limestone with some thin beds of clay. The limestone is very fine grained, locally siliceous, laminated of possible algal origin, and occurs in beds from several inches $(5 \mathrm{~cm})$ up to $3 \mathrm{ft}(0.9 \mathrm{~m})$ thick. The limestone exhibits primary depositional features such as shrinkage and solution cracks suggesting possible paleoexposure and (or) karst. 


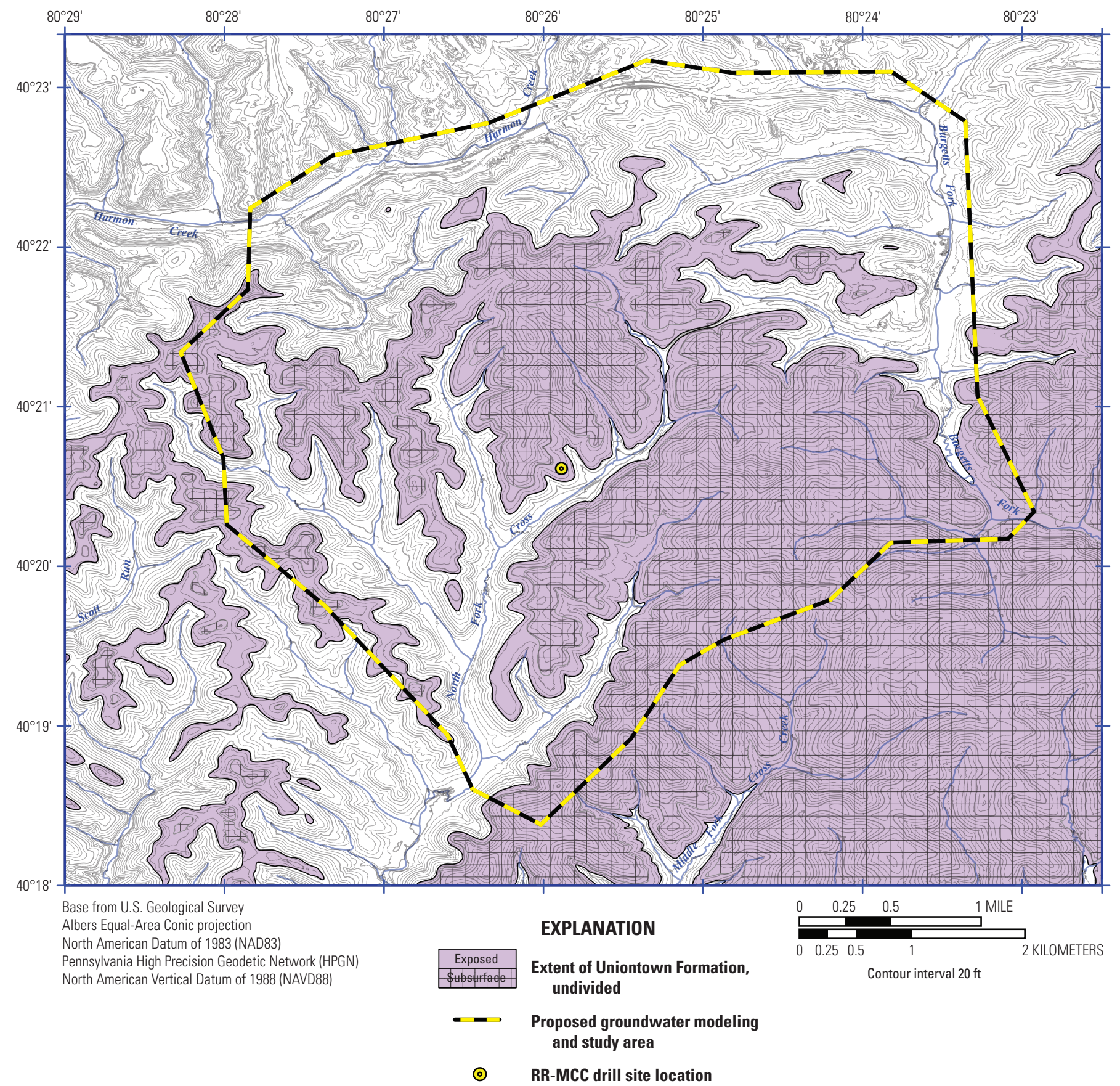

Figure 12. Map showing the distribution of the Uniontown Formation as both surface (exposed) and subsurface occurrences in the larger area of geologic coverage (AGC) (entire map) and the proposed groundwater modeling and study area (enclosed by black and yellow dashed line). Where not hachured, the Uniontown Formation occurs as surface exposures; where hachured, the Uniontown Formation is present in the subsurface overlain by younger units. Note that the abbreviation "RR-MCC" in the drill site name is short for "Range Resources MCC Partners L.P. Units 1-5H." Additional abbreviation: ft, feet. 


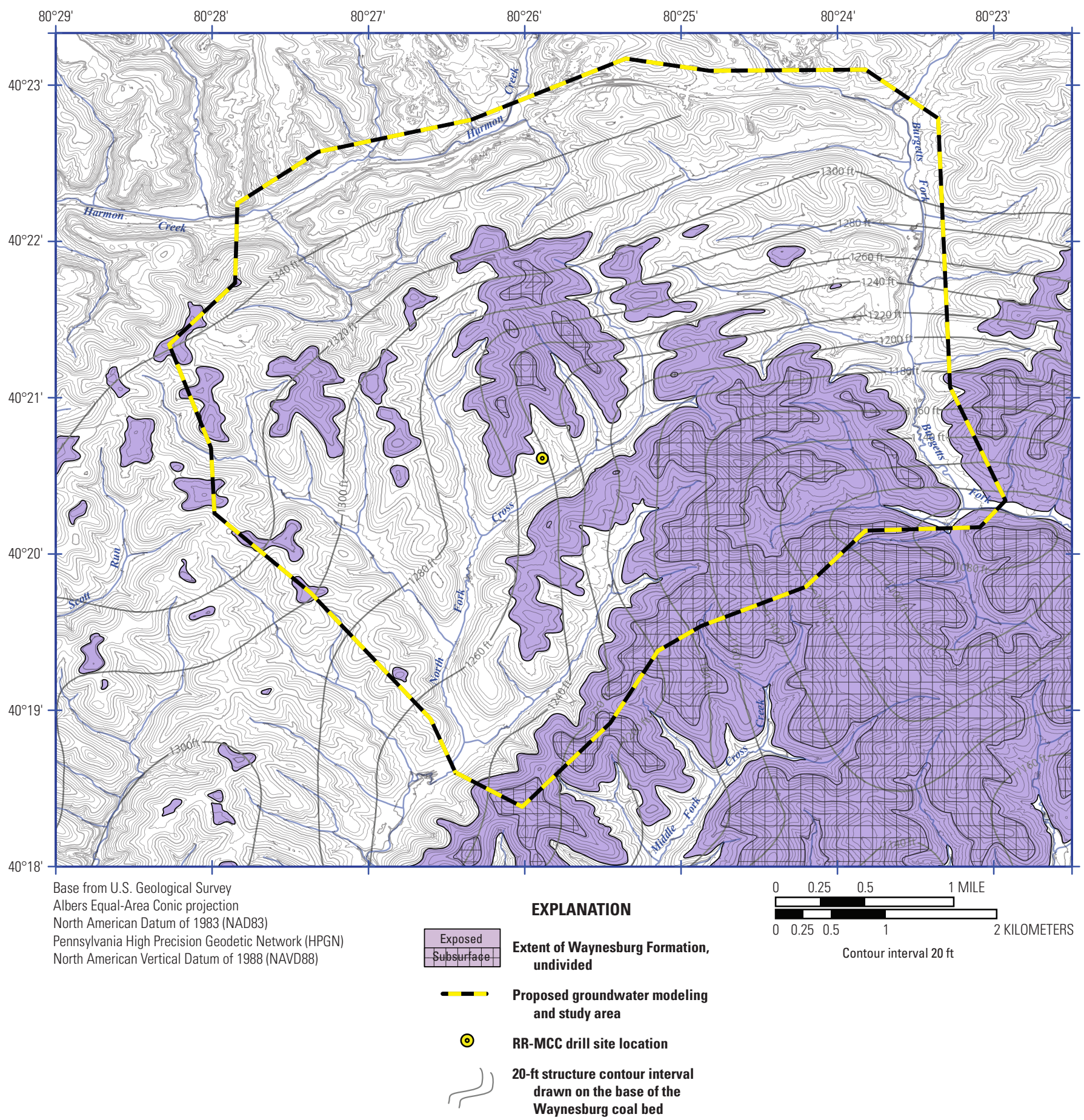

Figure 13. Map showing the distribution of the Waynesburg Formation as both surface (exposed) and subsurface occurrences in the larger area of geologic coverage (AGC) (entire map) and the proposed groundwater modeling and study area (enclosed by black and yellow dashed line). Where not hachured, the Waynesburg Formation occurs as surface exposures; where hachured, the Waynesburg Formation is present in the subsurface overlain by younger units. The 20-ft structure contours shown are drawn on the basal Waynesburg coal bed (see table 4 for link to online source used for structure contours). Note that the abbreviation "RR-MCC" in the drill site name is short for "Range Resources MCC Partners L.P. Units 1-5H." Additional abbreviation: ft, feet. 


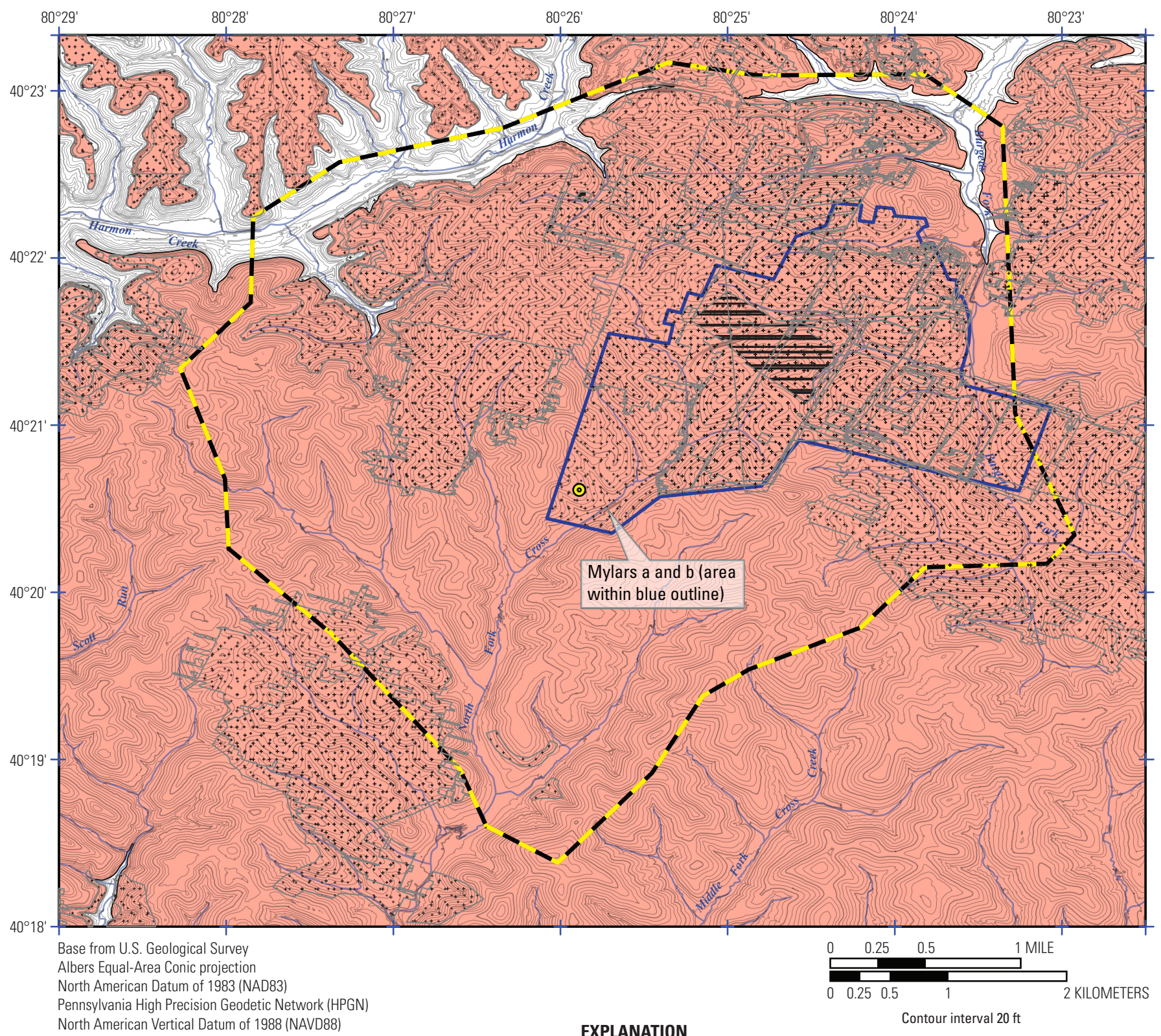

North American Vertical Datum of 1988 (NAVD88)

EXPLANATION

Extent of Pittsburgh Formation, surface and subsurface

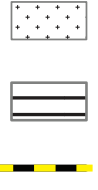

Area of mined surface and subsurface

Pittsburgh coal bed

Area of mined subsurface Waynesburg coal bed

Proposed groundwater modeling and study area

$\odot \quad$ RR-MCC drill site location

Figure 14. Map showing the subsurface extent of the Pittsburgh coal bed (orange color) overlain with the known extent of surface and subsurface mines in the Pittsburgh coal bed (stipple pattern) and overlying Waynesburg coal bed (striped pattern) (see table 4 for online sources used to determine mined areas). Along the lower valley slopes of Harmon Creek and in the adjoining hill tops to the north of Harmon Creek, the Pittsburgh coal bed has been strip mined. South of Harmon Creek and Burgetts Fork the Pittsburgh coal bed is mined by room-and-pillar methods in the subsurface. It is estimated that the Pittsburgh coal bed occurs at a depth of approximately 260 feet (70 meters) beneath the "RR-MCC" drill site. Note that the abbreviation "RR-MCC" in the drill site name is short for "Range Resources MCC Partners L.P. Units 1-5H." Additional abbreviation: ft, feet. 


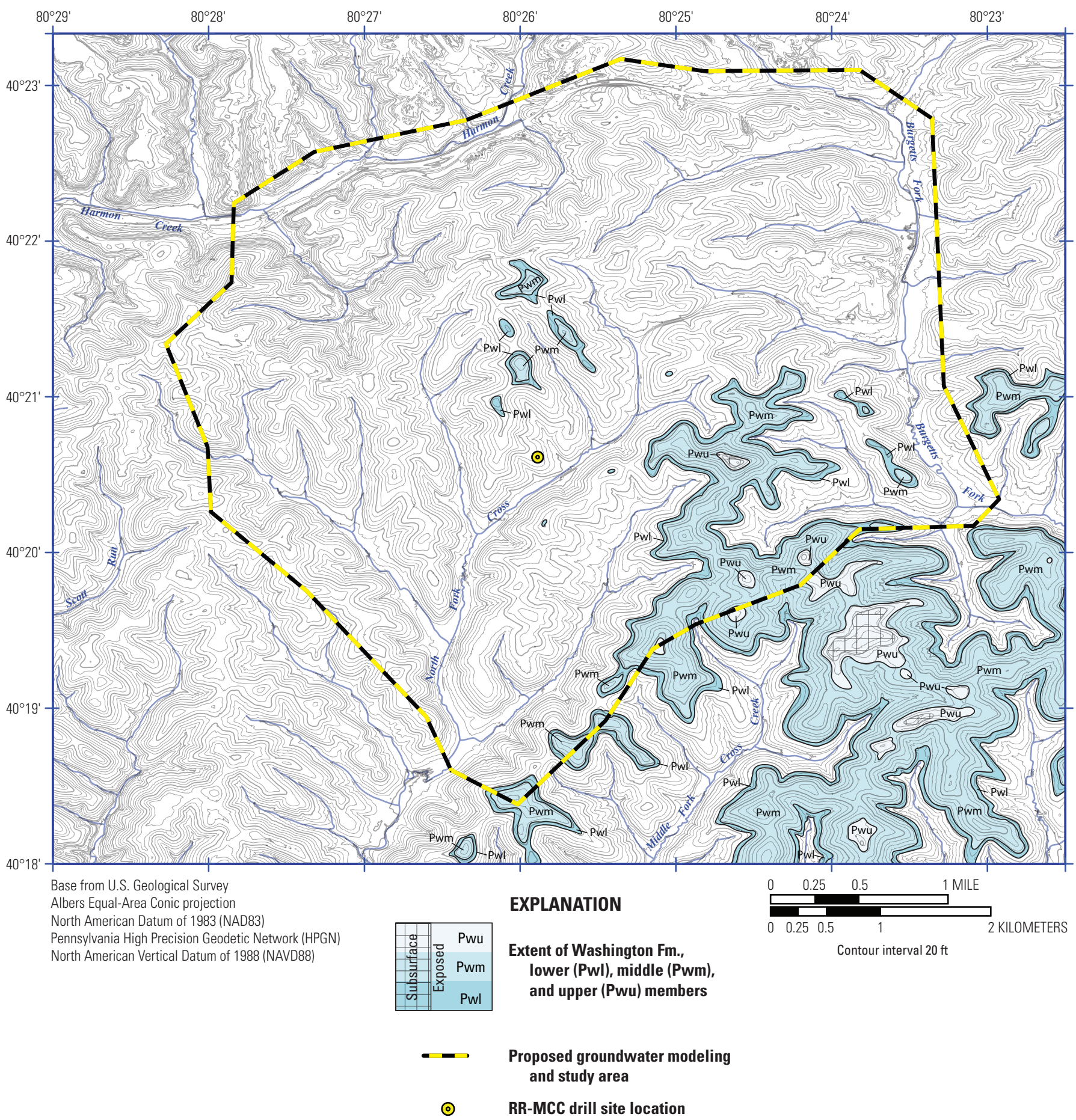

Figure 15. Map showing the distribution of the lower (Pwl), middle (Pwm), and upper (Pwu) limestone members of the Washington Formation in the larger area of geologic coverage (AGC) (entire map) and the proposed groundwater modeling and study area (enclosed by black and yellow dashed line). Where not hachured, the Washington Formation occurs as surface exposures; where hachured, the Washington Formation is present in the subsurface and is overlain by younger units. The few small hachured areas also correspond to the overlying Greene Formation, which is the youngest bedrock unit in the AGC that caps hill tops. Note that the abbreviation "RR-MCC" in the drill site name is short for "Range Resources MCC Partners L.P. Units 1-5H." Additional abbreviations: ft, feet; Fm., Formation. 


\section{Greene Formation}

The Greene Formation is the youngest bedrock unit mapped in the Avella 7.5-minute quadrangle by Schweinfurth (1976). It does not occur in the subsurface within the quadrangle; rather, it occurs as very poorly to nonexposed, commonly soil covered surface sections. It is present as small, isolated, and widely distributed erosional remnants that cap the higher hill tops in the downdip sections of the easternmost and southeasternmost parts of the larger quadrangle, and similarly within the AGC (fig. 10A). As an erosional remnant, a complete thickness of a representative stratigraphic section of the Greene Formation is not known to occur in the quadrangle, although Schweinfurth (1976) indicates a partial thickness of at least $60 \mathrm{ft}(18 \mathrm{~m})$ and possibly somewhat greater. The lithology of the Greene Formation is mainly assessed from available float within the quadrangle; the only in situ exposure being a thin, laterally persistent sequence of carbonaceous shale that directly overlies the upper limestone member of the underlying Washington Formation. Schweinfurth (1976) describes the remainder of the unexposed unit as mudstone interbedded with siltstone and sandstone. The occurrence of sandstone float along covered slopes suggests the presence of several massive beds. The sandstone is fine to medium grained, argillaceous, and moderately indurated, with float blocks having a maximum size of $1 \mathrm{ft}(0.3 \mathrm{~m})$ in length.

\section{Surficial Materials}

Quaternary age deposits consist of alluvium that overlies bedrock in some of the major stream valleys of Washington County. The alluvium is generally less than $60 \mathrm{ft}$ thick and consists of clay, silt, sand, gravel, and cobbles primarily derived from local bedrock.

In general, Pennsylvanian strata exhibit no significant post-depositional structural deformation in Washington County. The regional structural trend in the study area, which is based on structural contour mapping of the basal Pittsburgh coal bed (see "Structure Contour Maps" section of report), generally exhibits gentle dips commonly less than 1 to 2 degrees to the south and southeast.

\section{Geospatial Framework}

To support and facilitate the groundwater model and other investigative studies of the proposed study area, a GIS based geologic framework project was created using the software "Global Mapper version 16.2" by Blue Marble Geographics (http://www.bluemarblegeo.com/). Table 4 provides a listing of online resources of available digital geospatial data covering the study area that was directly imported into the project. Nondigital data (commonly hard copy maps) were scanned, imported into the project, and georeferenced. The GIS software was used to process these multiple data sets into theme layers that were then digitized and exported as geoprojected polygon, line, and point data shapefiles or as georeferenced raster theme maps.

A raster digital elevation model (DEM) dataset with a 3.2-ft horizontal ground resolution provides the geospatial framework for the study area. The DEM was generated from the lidar Log ASCII Standard (LAS) data that was collected during flights that took place from 2006 to 2008 for the PAMAP Program's 3.2-ft digital elevation model of Pennsylvania. The National Lidar Dataset is a combined Federal and State initiative to provide complete nationwide lidar coverage at the state level. However, the initiative and coverage is problematic due to the lack of (1) consensus of funding sources (Federal versus State), (2) coordination between States and Federal agencies, (3) data specifications and standards, and (4) geographic priorities such as the greater need of coverage for coastal and inland flood prone regions. Regardless, 30 States currently have some degree of lidar coverage that was coordinated through their own statewide initiative; 9 with complete coverage (including Pennsylvania of this report), 19 with partial coverage, and 2 with coverage in progress. Although the remaining 20 States have not yet coordinated their individual initiatives for lidar coverage, some do have partial coverage based on county initiatives to acquire and distribute lidar through their own specific needs and funding sources.

The DEM was constructed using the Lambert conformal conic map projection and the North American horizontal datum of 1983 (NAD 83). The 3.2-ft DEM and the lidar LAS files are downloadable as 10,000 ft x 10,000 ft tiles from the Pennsylvania Spatial Data Access (PASDA) website (see table 4 for links). Select tiles of both DEM and lidar data coverage of the study area were downloaded and imported into the Global Mapper version 16.2 software where they were projected into the Pennsylvania South FIPS 3702 zone (feet) of the State Plane Coordinate System using the NAD 83 datum. Other than the native projections of the DEM, lidar, and satellite imagery, all other data imported into the GIS project was processed and exported in NAD 83 for this study. The project data can be converted and exported in numerous other geographic projections and datums to accommodate the needs of other investigators.

Other georeferenced digital products available for download at the PASDA website (http://www.pasda.psu.edu/), such as political boundaries, roads, rivers, watershed boundaries, were also imported into the project. Additional digitized and nondigitized data that may or may not be georeferenced was also obtained from numerous Pennsylvania State websites (table 4). Examples include (1) scans of historical and recent maps of active and abandoned coal mines produced by mining companies, (2) scans of historical WPA (1935) maps of structure contours of economically exploited coal beds and maps showing the locations of active and abandoned oil and gas wells, and (3) downloadable statewide databases that provide locations of domestic, municipal, and industrial water wells.

\footnotetext{
${ }^{2}$ FIPS is an abbreviation for "Federal Information Processing Series." FIPS are numeric codes published by the Census Bureau that define unique geographic regions.
} 
Table 4. List of sources and links to online digital resources used to compile the geospatial part of this report.

[Abbreviations: DBF, DataBase File; DEM, digital elevation model; lidar, light detection and ranging]

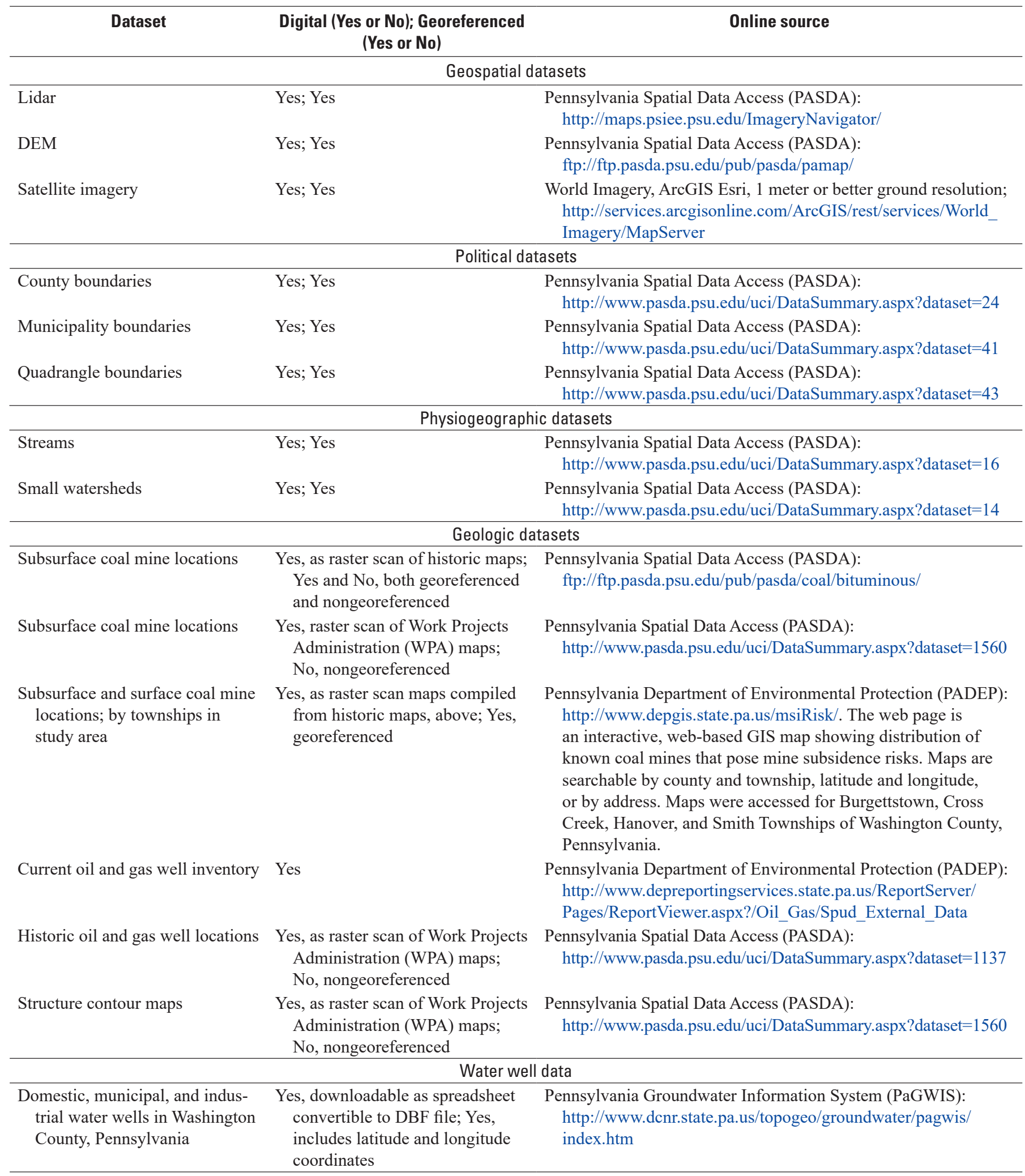




\section{Groundwater Modeling and Study Area}

The boundary of the proposed groundwater modeling and study area was taken from a figure provided in a working paper of the EPA's Quality Assurance Project Plan (QAPP). The figure was imported into the GIS geologic framework project where the boundary was digitized. The perimeter of the boundary is 16.27 miles $(26.18 \mathrm{~km})$ in length and it encloses and area of $16.45 \mathrm{mi}^{2}\left(42.72 \mathrm{~km}^{2}\right)$. The proposed groundwater modeling and study area is nearly centered on the RR-MCC drill site and the perimeter is nearly coincident with local, prominent physiographic features such as deeper river valleys and high ridge lines (figs. 3 and $6 A, 6 B$ ). These geographic features, in general, are expected to serve as groundwater flow boundaries. Within the proposed groundwater modeling and study area the total local relief is approximately $500 \mathrm{ft}(152 \mathrm{~m})$. The total depth of the groundwater model had not been determined, but it is expected to be greater than the total local relief of 500 feet. At depths below the local relief, the flow boundaries of the model may be extended into (and interact with) adjacent, larger, and more regional groundwater basins.

Figures $6 A$ and $6 B$ show the boundaries of the groundwater modeling and study area. On figure $6 A$ the boundary is plotted on parts of the Avella 7.5-minute and Burgettown 7.5-minute U.S. Geological Survey topographic maps. On figure $6 B$ the boundary is plotted on a 20 - $\mathrm{ft}$ contour interval topographic map generated from the 3.2-ft DEM that is overlain with the small watershed boundaries (PASDA; see table 4). The northern and adjacent northwestern boundaries are coincident with the deep valley of Harmon Creek that is the principal drainage of its watershed. The eastern and northeastern boundaries largely follow the deep valley of Burgetts Fork, also the principal drainage of its watershed. To the south and southeast, the boundary of the groundwater modeling and study area traces a high ridgeline that defines the boundary between two watersheds; the "North Fork of Cross Creek watershed" to the north and the "Middle Fork of North Fork of Cross Creek watershed" to the south. Lastly, the western and southwestern boundaries also follow a ridgeline that extends approximately 4.3 miles $(6.5 \mathrm{~km})$ from Cross Creek watershed in the south to Harmon Creek watershed in the north. The RR-MMC drill site is located in the headwaters area of the North Fork of Cross Creek watershed and is specifically within the deeper northeast to southwest trending valley that carries the southwest flowing North Fork of Cross Creek.

\section{Area of Geologic Coverage (AGC)}

A rectangular area of geologic coverage (AGC) that is slightly greater in size than the proposed area of the groundwater modeling and study area (figs. 7 and $10 A$ ) was selected for this study. The AGC is approximately 6.1 miles in length from north to south and 5.7 miles in length from east to west $(9.8 \mathrm{~km} \times 9.2 \mathrm{~km})$ and covers an area of approximately $35.0 \mathrm{mi}^{2}$ $\left(90.8 \mathrm{~km}^{2}\right)$. The northern and southern latitudes boundaries of the AGC are $40^{\circ} 23^{\prime} 20^{\prime \prime}$ and $40^{\circ} 18^{\prime} 00^{\prime \prime}$, respectively, and the eastern and western longitude boundaries of the AGC are $80^{\circ} 22^{\prime} 30^{\prime \prime}$ and $80^{\circ} 29^{\prime} 00^{\prime \prime}$, respectively. Although available statewide and countywide data were imported into the GIS project (see table 4; gas and oil well locations, coal mine locations, lidar, DEMs, geologic maps, etc.), only data occurring within the AGC was digitized and exported as geospatially projected shape files.

\section{Geology of the Area of Geologic Coverage (AGC)}

The best available, large-scale geologic map coverage of the proposed groundwater modeling and study area is the 1:24,000-scale geologic map of the Avella 7.5-minute quadrangle mapped by Schweinfurth in 1976 (fig. 7). This map covers all but the northernmost margin of both the groundwater modeling and study area and the encompassing AGC (fig. 7). Schweinfurth provided detailed mapping of recognized formations, members, and coal beds, although the placement of many unit contacts are inferred due to the lack of exposures. The northern margin of the AGC occurs in the adjoining Burgettstown 7.5-minute quadrangle to the north (fig. 7), which remains unmapped for bedrock geology at the scale of 1:24,000. Newport (1973) provides a geologic map of Washington County at a scale of 1:50,000 that covers the northern margin of the study area, unfortunately lithologic units are mapped at a more generalized stratigraphic group level, for example, for the Pennsylvanian Allegheny, Conemaugh, Monongahela, and Dunkard Groups, the mapped contacts are also generalized.

The available Avella 7.5-minute geologic map was raster scanned and imported into Global Mapper version 16.2 GIS software, where it was georeferenced and projected into the digital mapping project. At that time, the prospective case study of the RR-MCC drill site was not finalized; however, because it appeared that a spud date was imminent, it was decided that the geologic map attributes within the AGC would be immediately digitized. This was done to support the need for geologic data input for the siting of shallow and deep groundwater monitoring wells prior to the construction of the access road and drill pad and to support the need for model input parameters (structure, areal distribution and thickness of hydrostratigraphic units, faults, etc.) to the groundwater model development.

Nearly all the geologic attributes of the Avella 7.5-minute quadrangle occurring within the AGC were digitized. This includes both formation and member contacts, coal beds, structure contour elevations on the Pittsburgh coal bed, strip mines and spoil piles associated with contour mining of the Pittsburgh coal bed, and the location of oil and gas wells. Only the digitization of the Quaternary deposits was not completed due to the cancellation of the cooperative study. 


\section{Structure Contour Maps}

Available structure contour maps of select lithostratigraphic units in the AGC were acquired for the GIS project. These maps include, in descending order, the Upper Pennsylvanian Waynesburg coal bed of the Waynesburg Formation and the Pittsburgh coal bed of the Pittsburgh Formation (WPA, 1935; Schweinfurth, 1976; Skema, 1987), the Lower Mississippian Burgoon Formation (Harper and Laughery, 1987), and the Hundred-Foot sand of the Upper Devonian Venango Group (Griswold and Munn, 1907). All maps were imported into the GIS project where they were georeferenced. Only the structure contours of the Waynesburg coal bed and Pittsburgh coal bed were digitized for the study because they occur within the local relief of the groundwater model. These digitized products were exported as shape files to be attributed as input parameters to the groundwater model. Structure contours of the older, deeper Burgoon Formation and Venango Group were not digitized because the total depth of the groundwater model had not been determined at the time of cancellation of the study. Had the model depth been established, then these deeper structure contours would have been digitized to provide deeper, subsurface horizons of control to the flow model.

Between crop line data, borehole data, and detailed subsurface mine maps, the areal distribution and thickness of the widely exploited Pittsburgh coal bed located at the base of the Pittsburgh Formation is well known throughout Washington County, Pennsylvania. For this project, structure contour elevations of the Pittsburgh coal bed in the AGC were taken from work by Schweinfurth (1976) (fig. 11), the WPA (1935) 5-minute map series, and Skema (1987). Schweinfurth (1976) provides 20-ft structure contour elevations on the base of the Pittsburgh coal bed in his geologic map of the Avella 7.5-minute quadrangle. The WPA (1935; project number 19666) provides 20-ft structure contours on the base of the Pittsburgh coal bed and also on the base of the younger Waynesburg coal bed that defines the base of the Waynesburg Formation. This WPA project is mapped on four 5-minute quadrangle sheets that cover the entire AGC including the Burgettstown sheet number 4, Burgettstown sheet number 5, Burgettstown sheet number 7, and Burgettstown sheet number 8. Lastly, 20-ft structure contours developed on the base of the Pittsburgh coal bed in the Avella and adjoining Burgettstown 7.5-minute quadrangles are provided by Skema (1987). All maps with structure contour coverage of the AGC were scanned and imported into the GIS geology project where they were georeferenced, projected, digitized, and then draped over the DEM model.

The base of the Lower Mississippian Burgoon Formation was selected by Harper and Laughrey (1987) as a structure contour datum in southwestern Pennsylvania. Varying from 80 to 300 foot $(25-90 \mathrm{~m})$ in thickness in southwestern Pennsylvania, the Burgoon Formation consists of fine- to mediumgrained, medium- to massive-bedded sandstone typically interbedded with several shale members. Known to drillers as the "Big Injun sand" in the subsurface, the Burgoon Formation serves as a marker bed throughout western Pennsylvania and adjacent West Virginia (Harper and Laughrey, 1987). It was also a common target for oil and gas production in western Pennsylvania; to a lesser extent in the counties of Washington, Allegheny, and Westmoreland, and to a greater extent in the counties of Greene and Fayette to the south. The structure contour interval for the datum is $50 \mathrm{ft}(15 \mathrm{~m})$. The datum within the AGC is largely taken from depths of the base of the Burgoon Formation that were identified from a select number of described boreholes given in Griswold and Munn (1907). A raster scan of the map was imported into the GIS project where it was georeferenced and projected; however, it was not digitized due to the cancellation of the cooperative study.

Griswold and Munn (1907) provide 10-ft (3-m) structure contour elevations of the "Hundred-Foot sand," a unit that they included in the Lower Mississippian Pocono Formation, which is now recognized to occur in the upper part of the Upper Devonian (Upper Famennian) Venango Group. The "HundredFoot sand" is a driller's term for a marker unit, and is a common oil and gas producing target throughout western Pennsylvania. When a shaly interval is present in the middle of the "HundredFoot sand," it is then commonly subdivided into two sand units; the upper sand called the "Gantz sand" by drillers and the lower sand called the "Fifty-Foot sand" by drillers. In relative depth, the "Hundred-Foot sand" lies as little as $1,750 \mathrm{ft}$ to as much as $1,880 \mathrm{ft}$ below the Pittsburg coal bed of the Pittsburgh Formation (Griswold and Munn, 1907). Because of the relatively good depth control of the "Hundred-Foot sand" in drill holes within the AGC, this map was scanned and imported into the GIS project where it was georeferenced. Due to cancellation of the cooperative study this map was not digitized, although the attribute data on the map would have served as a deep structure datum for input into the groundwater model, if the model had been extended to these depths.

\section{Coal Beds}

Eight informally named coal beds are mapped in the larger area of the Avella 7.5-minute quadrangle by Schweinfurth (1976); however, in the smaller area of the AGC only five coal beds are mapped. The stratigraphic column in figure 8 shows only the five coal beds that occur in the AGC. Four of these five coal beds are present at the base of their associated formation of the same name; for example, the Pittsburgh coal bed of the Pittsburgh Formation is located at the base of the Pittsburgh Formation and defines the contact with the underlying Casselman Formation. The digitized contact between the Casselman and Pittsburgh Formations, therefore, provides the stratigraphic position and areal distribution of the Pittsburgh coal bed throughout the AGC. This is also the case for the Uniontown coal bed located at the base of the Uniontown Formation, the Waynesburg coal bed located at the base of the Waynesburg Formation, and the Washington coal bed located at the base of the Washington Formation. These four coal beds are the most laterally persistent and are recognized throughout the Avella 7.5-minute quadrangle. 
The digitized contacts between these formations also serve to locate the stratigraphic position and areal distribution of their similarly named coal beds within the AGC.

The only coal bed in the AGC that does not occur at a formation contact is the "Waynesburg A coal bed" that is present near the middle of the Waynesburg Formation (fig. 8). The "Waynesburg A coal bed," together with the distribution of alluvial deposits, were the only two remaining items not digitized in the AGC from Schweinfurth's (1976) geologic map. These two items were intended to be digitized but were not due to the cancellation of the cooperative study.

As mentioned earlier, the northern part of the AGC occurs within the southern part of the Burgettstown 7.5-minute quadrangle (fig. 7) that is unmapped for geology at a scale of 1:24,000; however, it was mapped at a scale of 1:50,000 by Newport (1973) and at a scale of 1:62,500 by Shaw and Munn (1911). Newport (1973) mapped only the more generalized lithostratigraphic groups rather than the more detailed levels of formations, members, and coal beds used by Schweinfurth in geologic mapping of the Avella 7.5-minute quadrangle. This was also the case by Shaw and Munn (1911), who mapped only the lithostratigraphic groups in their geologic map of the Burgettstown 15-minute quadrangle (includes both the Avella and Burgettstown 7.5-minute quadrangles).

For the northern area of the AGC that occurs within the unmapped southern part of the Burgettstown 7.5-minute quadrangle (fig. 7), a preliminary 1:24,000-scale geologic map was produced in this report in the GIS project (fig. 10A). Lithostratigraphic unit contacts were extended from the Avella 7.5-minute geologic map into the unmapped area principally on the basis of structure contour mapping (WPA, 1935; Schweinfurth, 1976; Skema, 1987) and crop line mapping (WPA, 1935; Skema, 1987) of the highly exploited Pittsburgh coal bed. Structure contour mapping clearly shows that the older Casselman and Pittsburgh Formations are the principal updip bedrock geology along the northern margin of the Avella 7.5-minute geologic map, and that these units exclusively extend into the adjoining unmapped area in the northern part of the AGC, shown in the cross section (fig. 10B). The intersection of digitized $20-\mathrm{ft}$ structure contour elevations of the Pittsburgh coal bed along with equivalent topographic contour elevations (that were generated from the $3.2 \mathrm{ft}$ DEM) provided control points for mapping and digitization of the Pittsburgh coal bed. As mentioned earlier, the Pittsburgh coal bed occurs at the base of the Pittsburgh Formation, and therefore marks the contact with the underlying Casselman Formation.

Placement of the digitized crop line of the Pittsburgh coal bed within the unmapped area of the AGC was validated by means of comparison to (1) existing crop line mapping of the Pittsburgh coal bed, (2) topographic maps, and (3) lidar results. Skema (1987) produced a crop line map of the Pittsburgh coal bed of very good reliability for the Burgettstown 15-minute quadrangle at a scale of 1:62,500. This map was not scanned, georeferenced, or digitized for the GIS project due to cancellation of the cooperative study. However, based on visual comparison of Skema's (1987) crop line map to the digitized crop line map developed in this report it was determined that both were congruent and no correction to the digitized crop line map was necessary. Historical and recent topographic maps of the Burgettstown 7.5-minute quadrangle were scanned, georeferenced, and projected into the GIS project. Mapped surface strip mines and spoil associated with contour mining of the Pittsburgh coal bed were then digitized. These digitized data were compared to the crop line map generated in this report for validation and were determined to be in very good agreement. Lastly, lidar data imported into the GIS project provided a highly detailed expression of ground surface disturbance associated with strip benches and spoil associated with Pittsburgh coal bed mining. Digitized line work of the Pittsburgh coal bed derived from structure contours and topographic maps were draped over the lidar-generated 3.2-ft DEM for comparison and validation. Figure $10 \mathrm{~A}$ shows the completed digitized geologic map of the AGC.

A geologic cross section was developed in order for the groundwater model to more accurately represent the subsurface geology (fig. 10B). The cross section extends across the AGC to include most of the exposed Pennsylvanian and Permian formations shown in figure $10 \mathrm{~A}$; excludes only the Greene Formation that is present as hilltop remnants. The cross section is oriented parallel to the direction of regional stratigraphic dip direction and it passes through the location of the RR-MCC drill site location. The elevation profile of the cross section was extracted from the 3.2-ft DEM. True formation thicknesses derived from nearby borehole logs and measured sections are not available for use in the generated cross section. Therefore, formation thicknesses illustrated in the cross section are relative and are based on one or more of the following: (1) the difference in elevation between the mostly flat-lying formation contacts along the cross-sectional transect as mensurated from the 3.2-ft DEM, (2) the difference in elevation between the Pittsburgh and Waynesburg coal beds as derived from the structure maps, and (3) formation thicknesses given in the explanatory notes and stratigraphic column of Schweinfurth (1976).

\section{Coal Mining}

In the surface to near-surface stratigraphic section of the AGC there are five informally named coal beds of both economic and noneconomic value (fig. 8). Thick, low sulfur coals, such as the approximately 5 -ft (1.5 m)-thick Pittsburgh coal bed, have historically been regionally exploited by subsurface "room-and-pillar" coal mining methods and more recently by "long wall" coal mining. Void spaces of abandoned room-and-pillar mines not only provide discharge areas for surrounding water-bearing rocks, but also act as conduits for groundwater flow. In long wall mining methods, the roof rock is allowed to collapse into the void space, and it is not uncommon that subsidence features associated with the collapse are expressed at the surface. These collapsed areas provide a more highly fractured zone for groundwater movement. In both cases, the chemistry of the associated 
groundwater is commonly acidic. Knowledge of the distribution of mined and unmined coal beds, and their differing mining methods, in both the surface and subsurface sections will provide additional input factors impacting the groundwater flow model and groundwater chemistry.

Historical and recent mine maps were obtained from various Pennsylvania State websites (table 4) that show the most current extent of surface and subsurface coal mining in the region. Available digitized and georeferenced products were directly imported in the GIS project, otherwise, nongeoreferenced hardcopy maps were scanned and imported into the project. Georeferenced mine maps were digitized with polygons representing areas of surface and subsurface mining; and where information was available, they were attributed with appropriate mine names.

Figure 14 shows the full subsurface extent of the Pittsburgh coal bed in the AGC and includes areas were the Pittsburgh coal bed has been mined. In the deeply incised drainages of Harmon Creek and Burgetts Fork and on the adjoining valley slopes and hill tops to the north, the Pittsburgh coal bed has been entirely strip mined. To the south of Harmon Creek the Pittsburgh coal bed gently dips 1 to 2 degrees to the south (into the subsurface) where it has been extracted by room-and-pillar coal mining methods. Also shown on the map is a small area of the overlying Waynesburg coal bed that has been locally mined in the subsurface.

Surface and subsurface mining of coal in the AGC is principally limited to the Pittsburgh coal bed, with lesser amounts of the younger Waynesburg coal bed being extracted. Prior to mining it is estimated that approximately 90 percent of the AGC was once underlain by the Pittsburgh coal bed, with the other 10 percent having been removed by erosional incision along Harmon Creek and Burgetts Fork in the northern part of the AGC. Based on available data, it is estimated that as much as approximately 50 percent of the Pittsburgh coal bed has been "mined-out" within the AGC, with most of the mining occurring in the northern half of the area. Subsurface mining in the AGC has been carried out using "room-andpillar" coal mining methods, rather than "collapse longwall" mining methods; therefore, the abandoned subsurface mines of the Pittsburgh coal bed within the AGC are flooded and remain open "mine pools."

At the location of the RR-MCC drill site, the structure contour map developed on the base of the Pittsburgh coal bed indicates that it occurs at a depth of approximately $260 \mathrm{ft}$ below the well pad. Most subsurface mine maps place the closest room-and-pillar mining at distances of 3,000 to $3,600 \mathrm{ft}$ to the east, north, and west of the drill site, with the exception of mylars "a" and "b" whose mined-out area is outlined in blue on figure 14. Scribed on mylar, map "a" and "b" are adjacent historical subsurface mine maps showing the mined-out areas of the Pittsburgh coal bed in the Burgettstown area, California mining district, southwestern Pennsylvania. Both mylars are scanned, georectified and posted for downloading (table 4). Mined-out areas of the Pittsburgh coal bed shown in mylars "a" and "b"(fig. 14) are generally in agreement with mine map data to the northeast and east; however, the location of the mylars suggest that Pittsburgh coal bed mining in the subsurface possibly extends to the southwest beneath the RR-MCC drill site. This may suggest the possibility that "mine pool" conditions exist beneath the drill site.

\section{Oil and Gas Wells}

As with coal mining, much of southwestern Pennsylvania has been exploited for oil and gas prior to the exploration and development of deep unconventional Marcellus shale-gas drilling. In Washington County, the earliest drilling for crude oil was in 1861 (Harper and Laughrey, 1987). Between 1886 and 1982, crude oil production alone from Washington County either equaled or generally exceeded production from the surrounding counties of Greene, Allegheny, and Beaver. However, oil production in Washington County, as with all of the surrounding counties, saw a steady decline from as much as 3.9 million barrels in 1890 to as little as 85,936 barrels in 1978, even with secondary recovery methods such as vacuum drive, gas drive, water flooding, and fracturing (Harper and Laughrey, 1987). In total, there are 20 named oil fields in Washington County that underlie approximately 10 to 15 percent of the county.

Excluding the most recent plays and development for deep, unconventional tight shale-gas of the Marcellus and Utica Shales, most gas production throughout southwestern Pennsylvania has largely exploited the shallower conventional Upper Devonian, Mississippian, and Pennsylvanian coarse- to medium-grained siliciclastic units. However, some wells have targeted deeper, Middle and Lower Devonian sub-Tully Limestone units in Washington County, such as the Ridgeley Sandstone and Huntersville Chert. Dates of early gas discoveries in the region were generally commensurate with that of oil, as wells drilled for oil frequently yielded producible gas rather than oil. Nearby the RR-MCC drill site, located approximately 6.3 miles to the southeast, is one of the earliest and most productive gas wells drilled in southwestern Pennsylvania, the "McGuigan \#1" (well number 657) of Mount Pleasant Township, Washington County (Griswold and Munn, 1907). Located in the Hickory gas field, it was drilled to a depth of 2,245 ft to the "Gordon sand" of the Upper Devonian Venango Group where initial production was estimated at 30,000 thousand cubic feet of gas per day (Mcfgpd) (Harper and Laughrey, 1987). In Washington County, there are approximately 35 named gas fields that roughly underlie 30 to 35 percent of the county.

Many, if not most, of the early deep drilling for hydrocarbon resources in the region were completed by "cable tool" methods. These boreholes were commonly uncased (to partially cased), and when abandoned no regulations concerning plugging existed. Even with later "rotary" drilling methods and the usage of drill casing, there were still very few regulations regarding the plugging of abandoned, orphaned, 
and nonproducing wells. Without proper well abandonment and plugging methods the risks remaining include (1) physical hazards, (2) open pathways allowing vertical cross migration of water of various qualities (for example, saline, high dissolved solids, acid mine pool) between confined and unconfined groundwater aquifer systems, and (3) the vertical cross migration of hydrocarbons such as oil and gas, or both, between hydrocarbon reservoirs and groundwater aquifers. Not until regulatory permitting of all new hydrocarbon wells in 1956, and with the Oil and Gas Act of 1984 (later amended in 1985), were statewide regulations established regarding the plugging of abandoned, orphaned, and inactive wells. As with hydrocarbon wells, the same risks apply to shallow domestic water wells, and the deeper municipal and industrial water wells. While water wells commonly do not penetrate to the depths of hydrocarbon reservoirs, the first two mentioned risks (physical hazards, cross migration of groundwater) concerning nonplugging of abandoned and orphaned water wells generally apply. Prior to 1966, with the establishment of the Water Well Drillers License Act (Act 610), there were no State regulations concerning the methods of plugging abandoned water wells.

For this project it was determined that the locations of both active and abandoned oil and gas wells would be useful information to communicate to other RR-MCC case study partners. For example, their locations may influence the siting of groundwater monitoring wells to be located around the drill pad. Further, their locations relative to existing domestic water wells within the AGC may influence the selection and sampling protocols of these wells for water chemistry analysis (figs. 16 and 17A, 17B). Where older abandoned oil and gas wells are more densely clustered, particularly in association with abandoned subsurface mine pools of the Pittsburgh coal bed, they may locally influence both unconfined and confined groundwater aquifer systems and water quality.

Figure 16 shows the locations of the total number of oil and gas wells spudded prior to 1976 that are known to occur in the AGC. The data are derived from the three following sources: (1) the Avella 7.5-minute geologic map by Schweinfurth (1976), (2) the 1935 WPA 5-minute map series (project number 25734), and (3) from select, historical subsurface coal mine maps that were downloaded from PASDA (table 4). Combined data from these sources indicated that a total of 237 active oil wells, 34 active gas wells, and 18 dry holes were drilled within the AGC, for a total of 239 drill holes (fig. 16).

Some of the earliest descriptions and locations of oil and gas wells in Washington County were mapped at a scale of 1:62,500 (15-minute quadrangle) by Griswold and Munn (1907), which were later complied into the WPA (1935) 5 -minute map series. Therefore, with the exception of Griswold and Munn (1907), all map data were scanned, imported into the GIS geologic framework project, georeferenced, and all oil and gas well locations were then digitized. It should be noted that up until 1956, when Pennsylvania passed a law requiring that all new hydrocarbon wells be permitted with accurate location information, the statewide inventory of oil and gas wells was poorly known. Because of this, it is highly likely that some additional, nonrecorded oil and gas wells (not digitized for this project) may exist in the AGC.

Pennsylvania maintains an electronic record system of more than 180,000 oil and gas wells in their Exploration and Development Well Information Network (EDWIN). Well data in the EDWIN system are available (1) online at https://edwin.onbaseonline.com/1500AppNet/Login.aspx, (2) by visiting the Pennsylvania Geological Survey's Pittsburgh and Middletown offices, and (3) by a 24-hour subscription service. At the time oil and gas wells data within the AGC was being compiled for this report, the online EDWIN system was not yet launched and well records were not accessible online and therefore not used in this report. This well records system would have likely provided additional useful information concerning well locations, depths, and production data of hydrocarbon reservoirs within the AGC.

The WPA 5-minute map series (1935; project number 25734) provides the locations of various types of wells including active oil wells, active gas wells, active wells that produce both oil and gas, abandoned oil and gas wells, dry holes, and wells with no records as of the year 1935 (table 4). Maps of this series that provide coverage of the AGC include the Burgettstown sheet number 4, Burgettstown sheet number 5, Burgettstown sheet number 7, and Burgettstown sheet number 8 . No numbering of the wells, nor an inventory or source data for the wells are provided with the WPA maps. Griswold and Munn (1907) provide numbering and generalized $\log$ descriptions for a select number of oil and gas wells in the Burgettstown 15-minute quadrangle that were compiled into the WPA 5-minute map series. Within the AGC, the WPA maps indicate that there are 200 active oil wells, 27 active gas wells, 18 dry holes, and one well with no record, for a total of 246 wells. No wells of combined oil and gas production and no abandoned wells are indicated to occur in the AGC.

Schweinfurth (1976) mapped the locations of active oil and active gas wells in the Avella 7.5-minute quadrangle. Forty four of these wells are located in the AGC, of which 37 are oil wells and 7 are gas wells. Schweinfurth (1976) did not provide a numbering system or any inventory or source data for the wells, with one exception being the "J. McCullough No. 1" oil well that is located in the southeast corner of the AGC (fig. 16; lat $40^{\circ} 18^{\prime} 31.6037^{\prime \prime}$, long $80^{\circ} 23^{\prime} 23.3702^{\prime \prime}$. None of Schweinfurth's (1976) oil or gas wells is located directly on any of the WPA (1935) wells, although 10 of his oil wells and three of his gas wells are located as little as $50 \mathrm{ft}$ (to as much as $300 \mathrm{ft}$ ) from the WPA wells, suggesting that some of these wells may possibly be the same. Comparison of the well inventories of the WPA (1935) data to that of Schweinfurth (1976) shows that over a period of 41 years the number of active oil wells declined by 163 and the number of active gas wells declined by 20 .

Based on the fact that 246 oil and gas wells had been drilled within the AGC up to the year 1935 (WPA data), it should be expected that many additional wells, of all types, were likely drilled after the WPA 5-minute map series was compiled. At the time the geologic framework project was 
cancelled, no attempt had been made to see if any of these wells were inventoried by the State of Pennsylvania or to determine their current production status.

Historical, detailed subsurface coal mine maps (downloaded from PASDA; table 4) commonly show the locations of preexisting oil and gas wells located in close proximity to the mine. This was done so as mining progressed the well borehole and casing could be purposely isolated within a supporting coal pillar. Upon digitizing the wells identified on the various available mine maps, many wells, if not all, showed a near congruence with the oil and gas wells that were previously digitized from the WPA (1935) 5-minute map series of project number 24734 (oil and gas wells).

Figure 16 shows that the locations of oil and gas wells mainly cluster in two areas, a larger cluster of oil wells in the eastern half of the AGC and a smaller cluster of gas wells in the western half of the AGC, with the RR-MCC drill site located between the two clusters. The oil wells group within the western and central part of the irregularly shaped, eastwest trending Burgettstown field; the easternmost part of the field extends approximately 1.5 miles eastward of the AGC to the town of Burgettstown.

Oil wells of the Burgettstown oil field (fig. 18) were drilled to depths of approximately 1,900 to $2,300 \mathrm{ft}$ where they targeted various sands of the Upper Devonian Chagrin Member of the Ohio Shale (Harper and Laughrey, 1987). Within the AGC, the most productive sand unit of the Chagrin Member is called the "Shannopin sand" by drillers. The Shannopin sand is commonly 10 to $20 \mathrm{ft}(3-6 \mathrm{~m})$ thick and rarely exceeds $25 \mathrm{ft}(8 \mathrm{~m})$ in thickness. The Shannopin sand can be traced as a thin, western equivalent to the lower part of a highly productive sand called the "Hundred-Foot zone" by drillers; the lower part is called the "Fifty-Foot sand" and the upper part is called the "Gantz sand" (both also driller's terms). The western extent of the Venango Group, as shown by the zero foot isopach map of Harper and Laughrey (1987; plate 7), is nearly coincident with the northsouth trending eastern margin of the AGC, with the Ohio Shale occurring to the west. Shaw and Munn (1911) indicate that very few of the approximately 150 wells in the Burgettstown oil field produced above 100 barrels per day (bbl/d), and later secondary recovery by water flooding and gas repressuring proved to be ineffective. As of 1935, the WPA indicates that there were 237 active oil wells in the Burgettstown oil field.

Gas wells in the eastern half of the AGC broadly group within the north-south trending Eldersville gas field (fig. 18), a field that is nearly encompassed by the AGC. As with the oil wells of the Burgettstown field to the east, gas wells of this field also target various sands of the Upper Devonian Chagrin Member of the Ohio Shale. In particular, Shaw and Munn (1911) indicate that gas production from the Eldersville field occurs from a 9- to 11-ft (3-4 m)-thick sand of the "HundredFoot zone." Isopach maps of the Venango Group by Harper and Laughrey (1987; plate 7) show that it does not occur in the area of the Eldersville gas field. Therefore, it is highly likely that this thin sand (called the "Hundred-Foot" by Shaw and Munn (1911)), is actually the "Shannopin sand." The productive gas horizon occurs at a depth of approximately 1,780 $\mathrm{ft}(543 \mathrm{~m})$ below the Pittsburgh coal bed in the northern part of the gas field, or along Harmon Run of the northern AGC; and it occurs at a depth of approximately 1,846 ft (563 m) below the Pittsburgh coal bed in the southern part of the gas field. The gas field occupies a structural high that is 50 to $150 \mathrm{ft}(15-46 \mathrm{~m})$ higher than the Burgettstown oil field located immediately to the east (Shaw and Munn, 1911).

Coincident with the southern and middle parts of the Eldersville gas field is the Cross Creek gas storage pool of the Columbia Gas Company (fig. 18). Of the approximately 14 gas storage pools located in southwestern Pennsylvania (includes Allegheny, Greene, and Washington Counties), 10 of these pools utilize various gas sand horizons of the Upper Devonian Venango Group and Ohio Shale, while 4 pools utilize younger Mississippian sands of the Pocono Formation (Harper and Laughrey, 1987). As of 1987, the Cross Creek gas storage project was inactive or abandoned, and no information concerning the year of initiation, storage area, capacity, pressure, storage sand unit, or depth was available. The targeted storage unit of the Cross Creek project may have been a prior gas producing sand of the Eldersville gas field of the Chagrin Member of the Ohio Shale, perhaps the "Shannopin sand" that is now considered nonproductive. 


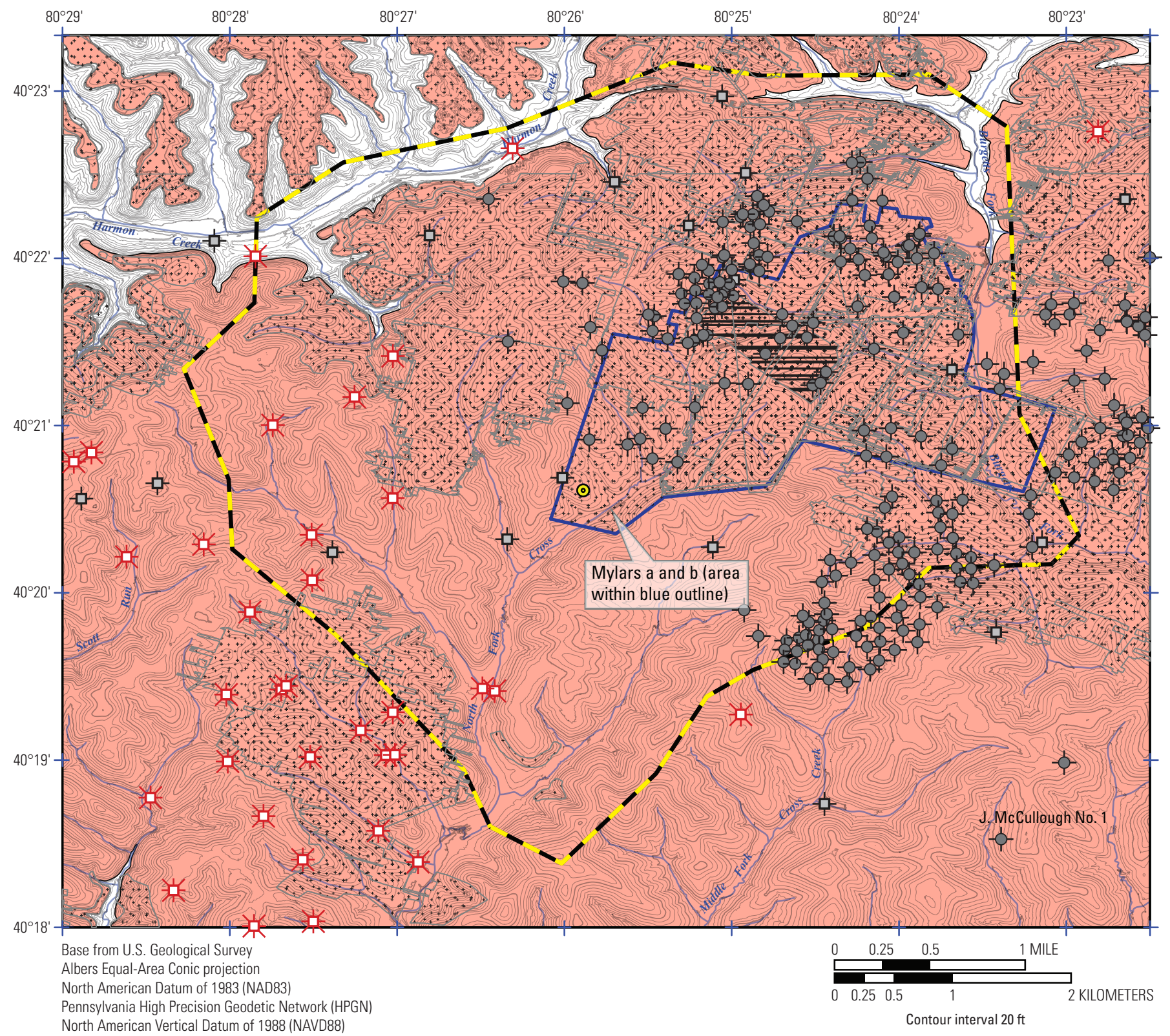

North American Vertical Datum of 1988 (NAVD88)

\section{EXPLANATION}

Historical oil and gas wells located in the area of geologic coverage (AGC); combined data from WPA (1935) and Schweinfurth (1976) surface and subsurface

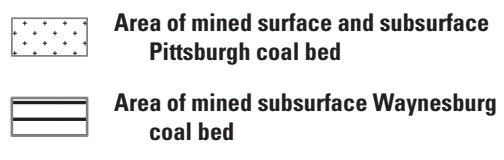

- Proposed groundwater modeling and study area

$\odot$

RR-MCC drill site location

Figure 16. Map showing the subsurface extent of the Pittsburgh coal bed (orange color) overlain with (1) known surface and subsurface mines in the Pittsburgh coal bed (stipple pattern) and Waynesburg coal bed (striped pattern); and (2) the locations of historic oil and gas wells, as well as the locations of dry holes. Oil and gas wells located in the areas of subsurface "room-and-pillar" mining of the Pittsburgh coal bed are commonly enclosed within a supporting coal pillar. Locations of historic oil and gas wells are digitized from the WPA map series at the Pennsylvania Spatial Data Access (PASDA) website (see table 4 for link to online source). Also see table 4 for links to online sources used for the surface and subsurface areas mined in the Pittsburgh and Waynesburg coal beds. The proposed groundwater modeling and study area is enclosed by the black and yellow dashed line. Note that the abbreviation "RR-MCC" in the drill site name is short for “Range Resources MCC Partners L.P. Units 1-5H.” Additional abbreviations: ft, feet; n, number of wells. 


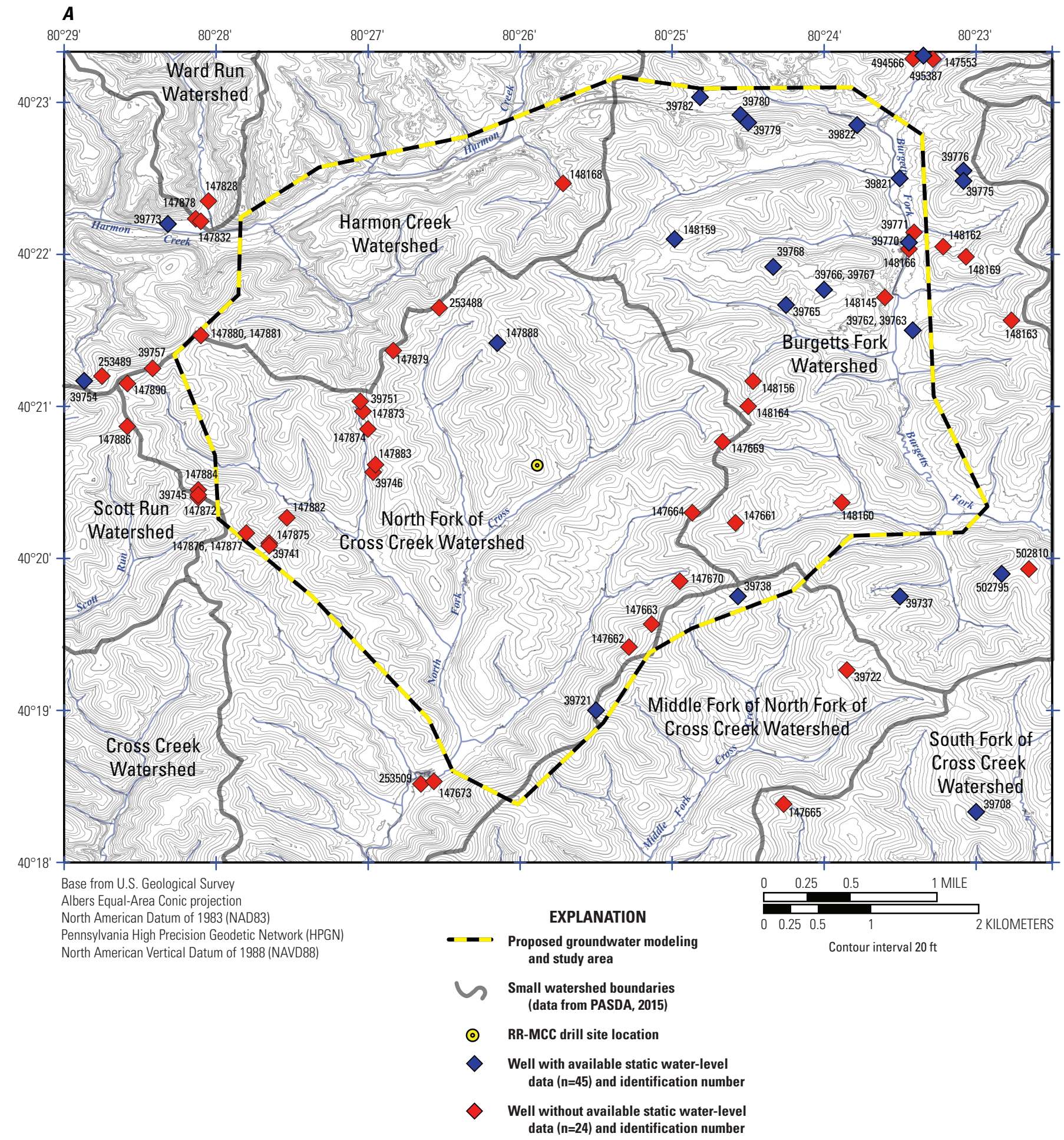

Figure 17. Maps showing the locations of domestic water wells in the topography and on bedrock geology of the small watersheds within the area of geologic coverage (AGC). $A$, Map showing the locations of domestic water wells in the topography and small watershed areas of the AGC (watershed boundary data from Pennsylvania Spatial Data Access (PASDA) (see table 4 for links to online source)). $B$, Map showing the locations of domestic water wells plotted in the surface bedrock geology of the AGC. Water well data from Pennsylvania groundwater information system (PaGWIS) (see table 4 for links to online source). The proposed groundwater modeling and study area is enclosed by the black and yellow dashed line. Note that the abbreviation "RR-MCC" in the drill site name is short for "Range Resources MCC Partners L.P. Units 1-5H." Additional abbreviations: $\mathrm{ft}$, feet; $\mathrm{n}$, number of wells. 


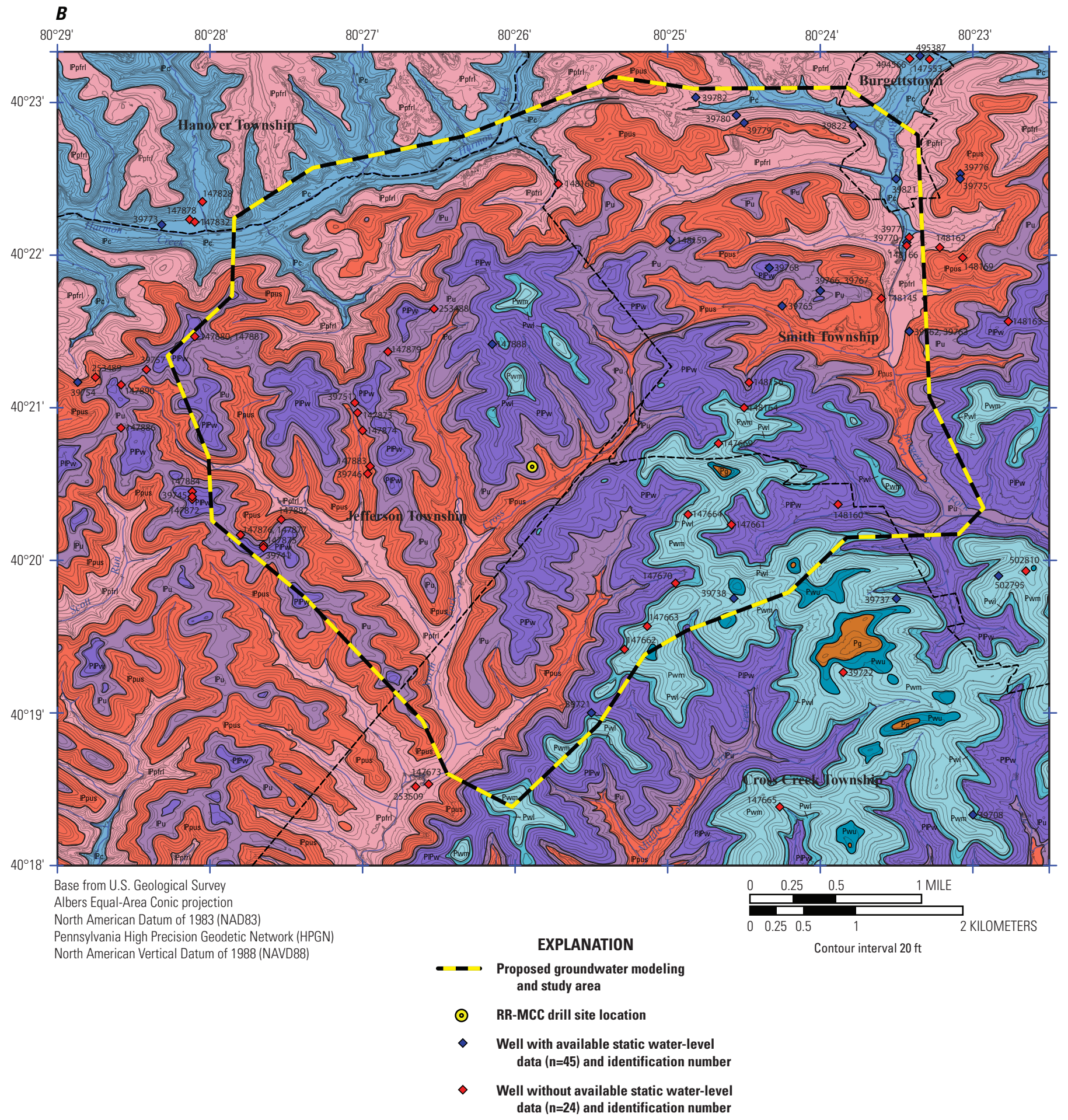

Figure 17. Continued. 


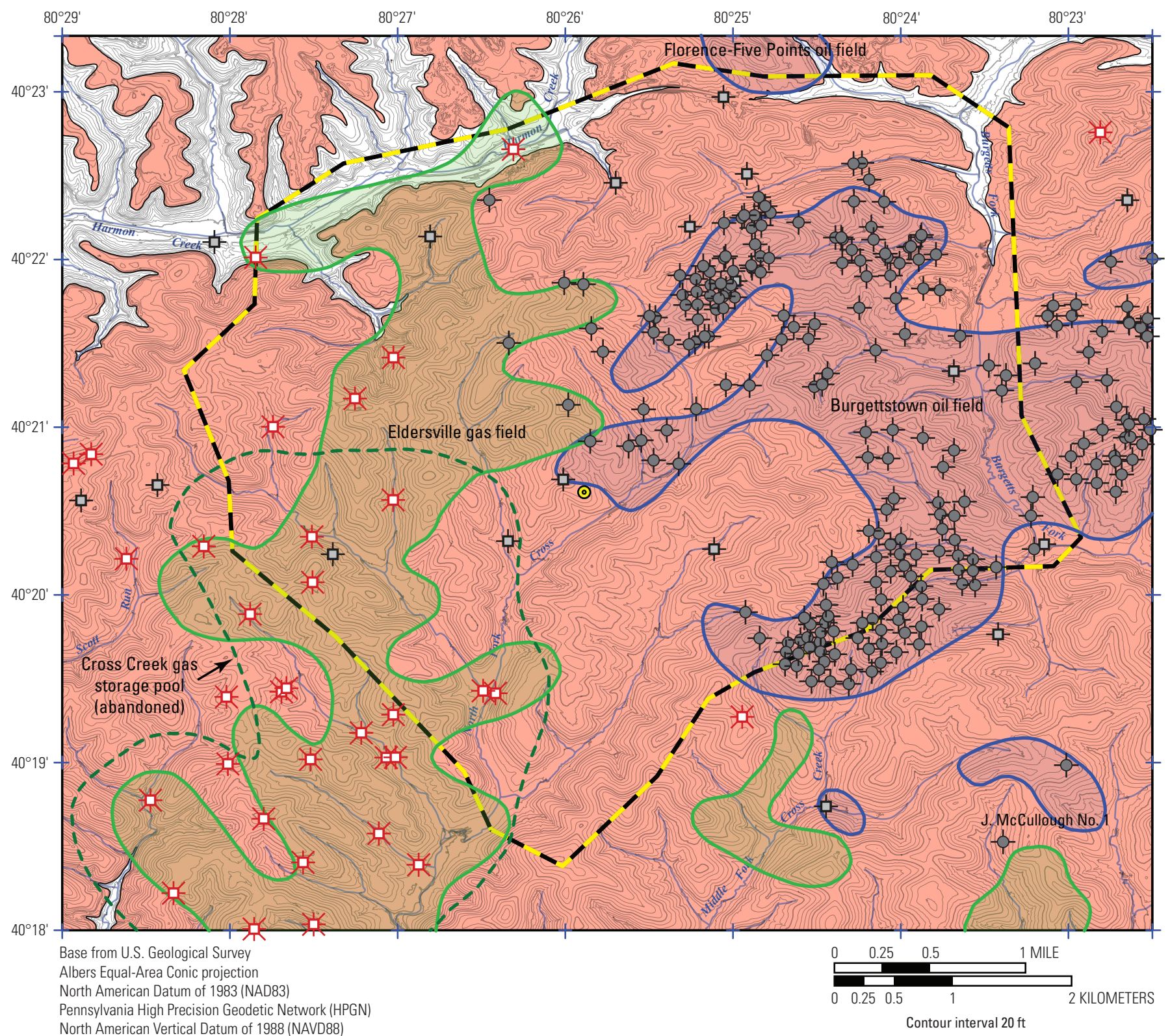

EXPLANATION

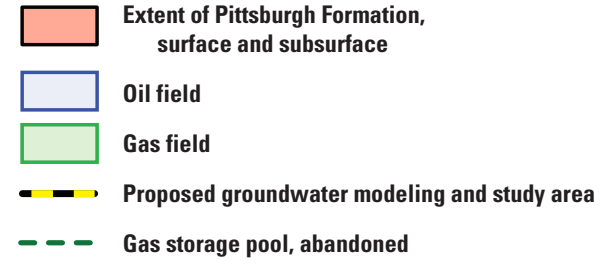

Historical oil and gas wells located in the area of geologic coverage (AGC) combined data from WPA (1935) and Schweinfurth (1976)

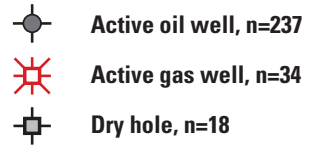

○ RR-MCC drill site location

Figure 18. Map showing the locations of active oil and gas wells and dry holes drilled prior to deep, unconventional Marcellus shale-gas drilling within the area of geologic coverage (AGC). These wells are principally drilled to medium- to coarse-grained siliciclastics of the Upper Devonian Venango Group. Oil wells cluster within the Burgettstown oil field to the east and gas wells cluster within the Eldersville gas field to the west. The locations of the oil and gas fields and the Cross Creek gas storage pool are from Harper and Laughrey (1987). The abandoned Cross Creek gas storage pool is delimited. The proposed groundwater modeling and study area is enclosed by the black and yellow dashed line. Locations of historic oil and gas wells are digitized from the WPA map series posted at the Pennsylvania Spatial Data Access (PASDA) website (see table 4 for links to online source). Note that the abbreviation "RR-MCC" in the drill site name is short for “Range Resources MCC Partners L.P. Units 1-5H." Additional abbreviations: ft, feet; $\mathrm{n}$, number of wells; WPA, Work Projects Administration. 
It is estimated that as many as 289 oil and gas wells occur in the AGC (fig. 16), of which 60 to 70 percent are located within the areas of subsurface Pittsburgh and Waynesburg coal bed mining. At the time when the wells were mapped, 237 were active oil wells, 34 were active gas wells, and 18 were dry holes. Abandoned oil and gas wells may serve as possible point sources of groundwater contamination due to corrosion of well pipes by acidic mine waters, improper or lack of plugging of the well, or increased downdip hydrostatic head pressure within "mine pool" waters.

\section{Water Wells}

Water well data were downloaded from the Pennsylvania groundwater information system (PaGWIS; http://www.denr. state.pa.us/topogeo/groundwater/pagwis/index.htm). For this project, countywide water well data for Washington County was downloaded in the Microsoft Access format. The Microsoft Access dataset was then converted and exported in "dBase" format. Water well locations with available latitude and longitude coordinates were then imported into and plotted within the GIS-based geologic framework project. The plotted water wells locations were attributed with the following available well information: drilling company, driller, identification number, drilling method, owner and address, depth, depth to bedrock, well yield, static water level, and the well water use. For a limited number of wells PaGWIS provides web links to raster scans of the driller logs that commonly provide a brief, highly generalized description of the rock types encountered during drilling and well yield from the encountered units.

Figures $17 A$ and $17 B$ provide two maps showing the locations of domestic water wells within the AGC that were available through the PaGWIS (see table 4 for link). Figure 17A shows the locations of water wells within the small watershed areas and figure $17 B$ shows their locations in the bedrock geology. All wells on both figures $17 A$ and $17 B$ display a well identification number that is searchable at the PaGWIS website provided in table 4 . Based on most recently available data, there are 69 domestic water wells within the AGC and all are used for domestic supply. Driller's logs provide static water-level data for 45 of the wells, but do not provide water level data for the remaining 24 wells.

In general, groundwater occurs in both confined aquifers and water table aquifers in Washington County, and the water-bearing zones are commonly encountered at depths of less than $150 \mathrm{ft}(46 \mathrm{~m})$. Most wells supply adequate water for domestic use at depths of 40 to $100 \mathrm{ft}(12-30 \mathrm{~m})$ below the surface; although in some wells the depth necessary for adequate domestic supply may be as deep as 150 to $200 \mathrm{ft}$ (46-61 m). The highly dissected plateau of the AGC provides approximately $500 \mathrm{ft}(152 \mathrm{~m})$ of total vertical relief, whose rolling hills are underlain by a surface bedrock geology consisting of six nearly flat-lying Pennsylvanian to Permian formations (fig. 10B). These formations include, in ascending order, the Casselman Formation, the Pittsburgh Formation, the Uniontown Formation, the Waynesburg Formation, the Washington Formation, and the Greene Formation. The lithology of each formation generally corresponds to a repetitive depositional sequence referred to as a cyclothem. While these formations may differ in their dominant lithology (some sandstone, some freshwater limestone, and others silty mudstone to muddy siltstone with fine sandstone), four of them, including the Pittsburgh, Uniontown, Waynesburg, and Washington Formations, exhibit a commonality in that they possess a coal bed and underclay at their base.

Together, the underclay and coal bed commonly form a couplet at the base of these formations, with the underclay representing a paleoweathering surface, or possibly a paleosoil, that supported the coal-forming forest. The underclays can vary from several tens of centimeters to many meters in thickness based on a combination of the duration and intensity of weathering and the preservation of the paleoexposure surface. Because of the nearly pure clay mineralogy of the underclays, they are commonly poorly transmissive to groundwater flow, thereby forming thin, but effective, widespread aquitards in the stratigraphic section. In contrast, the overlying coal beds commonly exhibit a system of two very close-spaced fracture sets, referred to as "face cleats" and "butt cleats." This system of dense fractures is highly transmissive, serving as a conduit for groundwater flow. Five stratigraphically successive, relatively flat-lying (less than 2 degree dip to the southeast) couplets consisting of an underclay and an overlying coal bed include the Pittsburgh coal bed, the Uniontown coal bed, the Waynesburg coal bed, Waynesburg A coal bed, and the Washington coal bed in the proposed groundwater modeling and study area and the AGC. The vertical stratigraphic distance between the lowest underclay/coal bed couplet (Pittsburgh coal bed) and uppermost underclay/coal bed couplet (Washington coal bed) in the AGC is approximately $280 \mathrm{ft}$. Given that the total relief within the AGC is approximately $500 \mathrm{ft}$, with most hill masses varying from 200 to $300 \mathrm{ft}$ in local relief, it is not uncommon that at least 3 to 4 , if not all, of the underclay/coal bed couplets will occur within the relief of a hill mass. Stratigraphically lower couplets commonly occur at or close to the bases of hills within the more deeply incised stream valleys and they exhibit the most continuous lateral extent in the subsurface (compare figs. 8 and $10 B$ for stratigraphic position of coal bed couplets and their distribution in the cross-section topography). Conversely, stratigraphically higher couplets occur at higher elevations in the hills where, due to more extensive erosional stream incision, they are less laterally continuous and commonly occur as erosional hilltop remnants.

The occurrence and distribution of these multiple underclay/coal bed couplets were digitized as GIS shapefile polygons. In this way, their subsurface areal extent, the stratigraphic distance between them, and the intervening lithology that separates them, could be used as input parameters for the model. Where two or more of these horizontal couplets are present in the local relief of a hill, it is expected that they 
may provide an effective barrier to the downward infiltration of seasonal rainfall, and instead direct any infiltration and groundwater flow laterally to hill slopes through coal bed cleats and secondary lithologic fracture porosity of intervening sandstones, limestones, and silty shales.

In support of the water chemistry monitoring phase of domestic wells of the cooperative study, it was felt that the location of water wells in the bedrock geology may provide useful information concerning the possible variation in the quality and chemistry of groundwater that is stored in both shallow confined and shallow unconfined aquifers. For example, are there variations or similarities in the quality and chemistry of water from wells that have been drilled in similar, near similar, or differing bedrock lithologies (for example, clastic versus carbonate lithologies), and are there variations or similarities in groundwater chemistry from wells that encounter coal beds. This may help determine how water yield and water quality is controlled by numerous local geologic criteria, such as variation in lithology, occurrence of coal beds, density and trend of fractures in various lithologies, and the influence of subsurface coal mining as a dewatering agent of the shallow aquifer. Williams and others (1993) provide a similar analysis of the effects of coal mining on both the surface and subsurface hydrology and of the quality of water from various surficial and bedrock units of Washington County, Pennsylvania. For example, the data of Williams and others (1993) from Washington County including (1) water well locations with the associated depth, (2) hydrogeologic units encountered, (3) depth to groundwater, (4) measured water yield, and (5) water quality, would have provided useful input into the cancelled prospective case study.

\section{Discontinuity Analysis}

Discontinuities in sedimentary rocks of the proposed study area are expected to include bedding plane discontinuities associated with primary depositional processes and systematic tensional fractures associated with regional tectonic regimes. In the nearby Pittsburgh area, Kohl (1980) provides a discontinuity analysis of the sandstone, shale, limestone, and coal lithologies of the Glenshaw, Casselman, Pittsburgh, and Uniontown Formations that includes attitude (strike and dip), spacing distance, and jointed bed thickness. In the Appalachian Plateau of southwestern and central Pennsylvania, Nickelsen and Hough (1967) provide attitude and spacing distance data for systematic and nonsystematic tensional joints in Pennsylvanian and Permian cyclic sedimentary rocks of shale, sandstone, and coal.
In the Quality Assurance Project Plan (QAPP), it was proposed that a discontinuity analysis would be conducted congruent with mapping at both the close-up outcrop scale and at the overview scale of regional fracture trends. Where adequate exposures exist in the study area, a outcrop-scale discontinuity analysis will include quantitative scan-line measurements and descriptions of bedding plane and tensional fractures that are associated with the differing rock types of mapped stratigraphic units. Scan-line data are expected to include bedding orientation and thickness and the associated spacing distances, persistence, and aperture conditions of the discontinuities. Where stratigraphic units are either unexposed in the surface bedrock section or they occur exclusively in the subsurface of the study area, the analysis of outcrop-scale discontinuities of those units will be described from available, nearby exposed sections.

In the development of the groundwater model it will be important for the modelers to know the influence and contribution of fracture flow, if present, in any of the various lithologies. For example, map units in the study area that principally consist of sandstone will commonly have higher primary porosities than map units that mainly consist of limestone; however, secondary fracture porosity is commonly much greater in limestones than in sandstones due to solution enhancement or widening of discontinuities. Coal beds, which are numerous in the near-surface bedrock section, may commonly act as lateral flow conduits for groundwater due to (1) the very close spacing distance (high density) and high persistence of face and butt cleats (fractures) and (2) because they are generally underlain by relatively impervious underclays that promote lateral flow.

Analysis of regional- and local-scale fracture trends and possible surface expressions of mine subsidence will be conducted from available remote sensing data, such as satellite imagery, aerial photography, and lidar. Figure 19 provides a hill-shade overview of the study area generated from the lidar data that shows both strong and weak control of fracture lineaments on the orientation of deeper stream drainages and shallower hill-slope incision. For example, in the southwestern part of the image there is strong fracture control on both the northwest-southeast orientation and regular spacing distance $(\sim 0.3 \mathrm{mi}(\sim 0.5 \mathrm{~km}))$ of secondary stream valleys. Additionally, within the northwestern, north-central and central parts of the study area there are subtle east-west orientations of the incipient, shallow hill-slope drainages that are likely controlled by fracture lineaments. These briefly assessed fracture lineaments, being more deeply seated, commonly vertical, and transecting the stratigraphic section, may provide potential pathways for groundwater movement and mixing between otherwise discrete aquifer zones. 


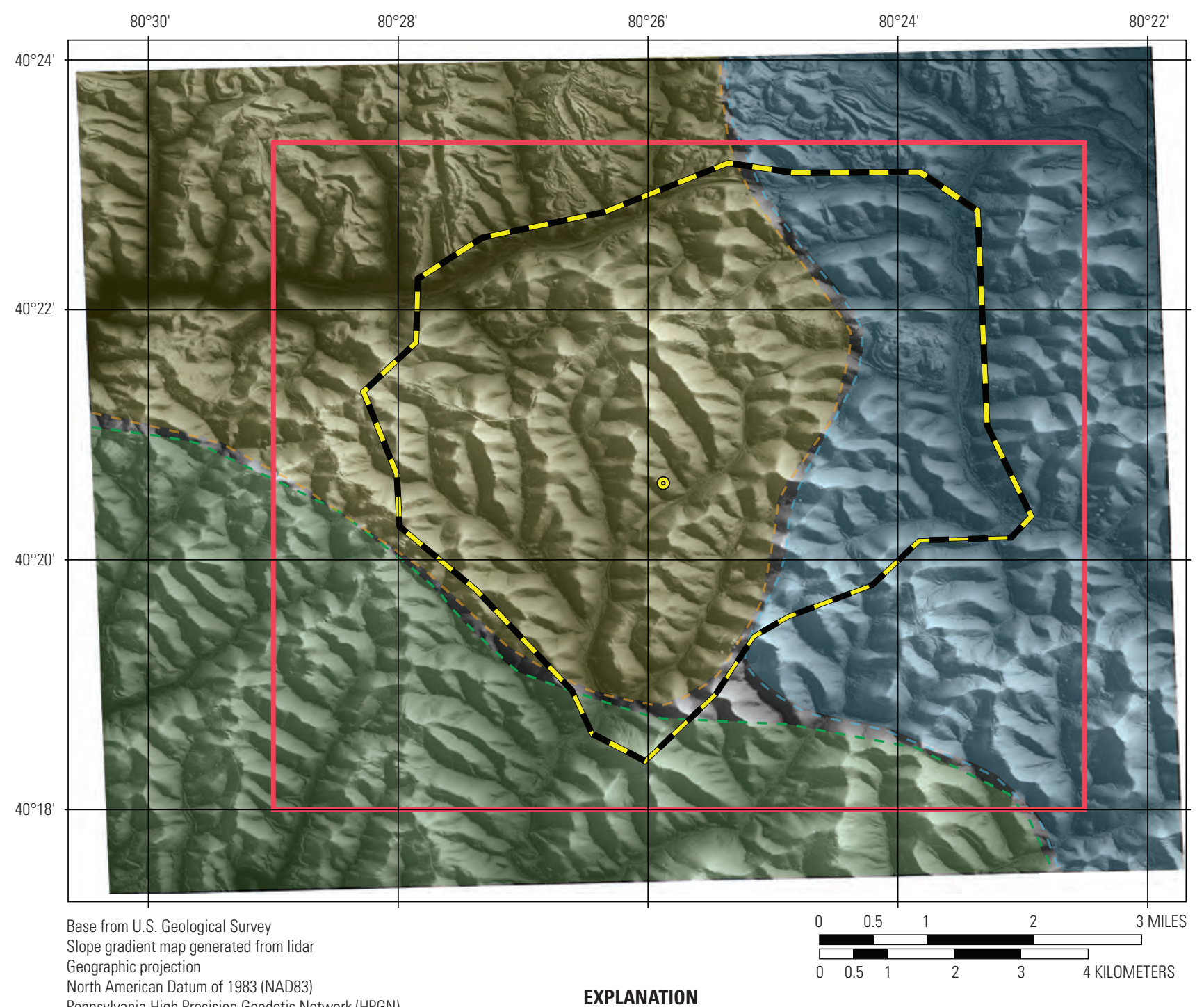

Interpreted fracture control of drainage areas

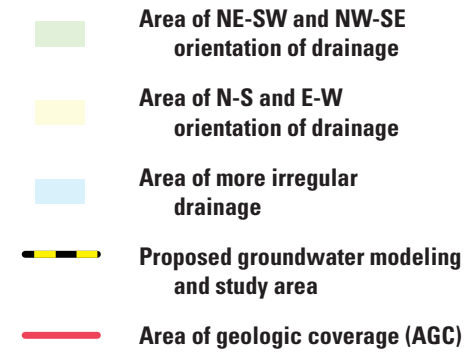

○) RR-MCC drill site location

Figure 19. Map showing hill-shade topography of the area of geologic coverage (AGC) (red box) showing the control of local, small-scale fracture lineaments on streams and hill-slope incision. The boundary of the groundwater modeling and study area is enclosed by the black and yellow dashed line. Strong fracture control on the NE-SW orientation of stream drainage is shown in the southwest corner of the AGC (area of green transparent overlay). More subtle, weaker fracture control on the N-S and E-W orientation of stream drainage is shown in the central and northwestern parts of the AGC (area of yellow transparent overlay). The more irregular orientation of stream drainage in the eastern part of the study area suggests a weaker, more random orientation to fractures (area of blue transparent overlay). Note that the abbreviation "RR-MCC" in the drill site name is short for "Range Resources MCC Partners L.P. Units 1-5H." Additional abbreviations: ft, feet; E-W, east-west; N-S, north-south; NE-SW, northeast-southwest. 


\section{Summary}

This report describes the methodology that was used in conducting a large-scale or detailed geologic framework study. It results from the prospective environmental monitoring case study of a deep, unconventional Marcellus shale-gas hydraulic fracturing drill site located in Washington County, Pennsylvania. The drill site is the Range Resources MCC Partners L.P. Units 1-5H location (or "RR-MCC"). Under the lead of the Environmental Protection Agency (EPA), other principal partners in the case study include the U.S Geological Survey (USGS), Department of Energy (DOE), Pennsylvania Geologic Survey, and the Pennsylvania Department of Environmental Protection (PADEP).

As a participant, the USGS was approached with the task of providing available geologic data to support the objectives, tasks, and sampling procedures of the case study. In large part, this involved the characterization of the near-surface and deep-subsurface bedrock geology and of the distribution of unconsolidated surficial materials. The surrounding boundaries of the proposed groundwater modeling and study area encircle the "RR-MCC" drill site at distances of approximately 1.25 to 3.0 miles $(\sim 2-4.8 \mathrm{~km})$ and are coincident with major watershed boundaries. Although the project was cancelled, geologic data within this area would have been utilized for (1) the siting of numerous shallow and deep groundwater monitoring wells to be drilled in close proximity to the RR-MCC drill pad location and along one of its horizontally deviated production drill legs, (2) the development of a deep groundwater flow model that is coincident with the proposed study area, and (3) the distribution and characterization of residual in situ soil and stream sediments.

The methodology of this geologic framework study is intended to provide an example and guidance for obtaining, compiling, and interpreting available geologic data and, when possible, conversion of this geologic data into a digitized, geospatial GIS format. Various digitized and geospatially referenced GIS data can then be exported into different GIS formats to provide shared, integrated support for the science objectives and needs of other participating partner agencies in the study. Data compiled in this framework study, and for future studies, should include the following: (1) geologic, surficial, and structure maps at the most optimum scale and detail possible, (2) detailed descriptions of geologic bedrock units and structure, (3) the highest resolution digital elevation models (DEMs) available, (4) the highest resolution satellite imagery available, (5) surface water and groundwater data, (6) water well data, and (7) ancillary geologic information that is exclusive to the region of study that (for this report) includes the locations of preexisting surface and subsurface economic coal mines and the locations of active and inactive oil and gas wells.

Although the best available large-scale geologic, surficial, and structure map coverage should be obtained for the study area, the size of the study area, along with the study objectives and time limitations will determine the level of detail that can be complied into the GIS project of the geologic framework study. In addition, older non-GIS based, nondigitized, and nongeoreferenced map sources may prove to be difficult to work with. Fortunately, more recently, most State geologic surveys and the USGS are conducting and publishing geologic maps as digital GIS products while older geologic maps of various scales are being complied, scanned, and georeferenced in GIS-based programs; however, this is just a small selection of available map products. The availability of various map products that provide coverage of the study area can generally be viewed and downloaded from the appropriate State geologic survey website, which commonly provides State, county, and some quadranglescale maps; and map products can also be viewed and downloaded from the USGS National Geologic Map Database (http://ngmdb.usgs.gov/ngmdb/ngmdb_home.html).

Descriptive geology of the study area is commonly available as explanatory notes to available geologic maps, whether they are statewide, countywide, or quadrangle-scale maps. Regional to local geologic studies that are available through open-source literature also provide useful geologic information, particularly when accompanied by sketch maps and cross sections of varying detail that can be imported into the GIS project. Available lithologic descriptions that provide grain-size information (fine, medium, or coarse grained), sediment type (clastic versus carbonate), and degree of induration (amount of cementation, compaction, and (or) dissolution), allows groundwater modelers to determine hydrostratigraphic units that, when used in conjunction with subsurface structural information, provide the working framework of the groundwater flow model.

High resolution terrain information (particularly derived from lidar data) has become the standard for digital elevation modelling in GIS projects. Lidar data can generally be obtained through State clearinghouses, such as a university and (or) State agency, and through the USGS Earth Explorer website (http://earthexplorer.usgs.gov/). Use of high resolution digital elevation models (DEMs) in the GIS framework project allows for the generation of elevation contours, hill shading, slope aspect, slope gradient, watershed boundaries, and 3-D viewing of draped, georeferenced map data.

Satellite imagery for this project was obtained through the Esri World Imagery map service which provides 0.3 -meterresolution imagery of the continental United States. This data, particularly when used in conjunction with the high resolution digital elevation model data and imported geologic map data, allows for a more refined interpretation of land-use patterns in the study area (forests, agricultural use, urban development, strip mines, spoil, etc.) as it relates to the underlying terrain and geologic attributes. Additionally, historical aerial imagery available through the USGS Earth Explorer website at scales of 1:24,000 to 1:80,000 allows for comparison of land-use changes as early as 1952 .

Available surface water and groundwater information (at various scales) may provide useful baseline inputs for the groundwater modelers. The determination of watershed properties in the study area would include attributes such as 
watershed boundaries and total area, the presence of inclusive streams, the location and discharge rates of springs, and the terrain elevation and slope gradient. With the exception of springs, most of these attributes can be generated from the DEM by using the terrain analysis tools included in the GIS program. This information provides modelers with inputs concerning the total area and (or) specific points within the watershed that may control infiltration, recharge, and (or) discharge rates from the groundwater system to be modeled. Groundwater data are commonly provided through State agencies, such as geological surveys and (or) departments of environmental and natural resources, as broader county, multi-county, and basin-scale reports. Rarely is it found at the site-specific scale of a geologic framework study.

As with groundwater data, water well data can generally be acquired through State agencies, geological surveys and (or) departments of environmental and natural resources, as downloadable digital data. Information commonly includes the latitude-longitude coordinate location, the well depth, the depth to static water level, the well yield and pump test results, and the identification of the water-bearing hydrostratigraphic units. For a limited number of wells, a lithologic log is available, though the lithologic descriptions can be highly subjective and variable between different drillers. When water well locations are plotted in the geology of the GIS project, their depth to water and rate of groundwater yield can provide useful information to groundwater models concerning the hydrostratigraphic characteristics, such as transmissivity of the geologic units encountered in the subsurface.

\section{References Cited}

Berryhill, H.L., Jr., and Swanson, V.E., 1962, Revised stratigraphic nomenclature for Upper Pennsylvanian and Lower Permian rocks, Washington County, Pennsylvania, in Geological Survey Research 1962; Short papers in geology, hydrology, and topography-Articles 60-119: U.S. Geological Survey Professional Paper 450-C, p. C43-C46. [Also available at https://pubs.er.usgs.gov/publication/pp450C.]

Blue Marble Geographic, 2017, Global Mapper version 16 GIS software: http://www.bluemarblegeo.com/products/globalmapper.php. [U.S. Geological Survey site license agreement.]

Esri, 2014, ArcGIS REST services directory-World_Imagery (MapServer): Esri web page, accessed July 22, 2015, at http://services.arcgisonline.com/ArcGIS/rest/services/ World_Imagery/MapServer.

Griswold, W.T., and Munn, M.J., 1907, Geology of oil and gas fields in Steubenville, Burgettstown, and Claysville quadrangles, Ohio, West Virginia, and Pennsylvania: U.S. Geological Survey Bulletin 318, 196 p., 12 pls. [Also available at https://pubs.er.usgs.gov/publication/b318.]
Groundwater Protection Council [GWPC] and Interstate Oil and Gas Compact Commission [IOGCC], 2015, FracFocus Chemical Disclosure Registry-Find a well: GWPC and IOGCC web page, accessed July 22, 2015, at http://fracfocus.org/.

Harper, J.A., and Laughrey, C.D., 1987, Geology of the oil and gas fields of southwestern Pennsylvania: Pennsylvania Geologic Survey, Fourth Series, Minerals Resource Report 87, 165 p., 8 pls. [Also available at http://www.denr.state.pa.us/ topogeo/publications/pgspub/mineral/index.htm.]

Kohl, W., 1980, Jointing in outcropping rocks of Pennsylvanian age, central greater Pittsburgh region, Pennsylvania: U.S. Geological Survey Open-File Report 80-23, 20 p., 4 pls. [Also available at https://pubs.er.usgs.gov/publication/ ofr8023.]

Newport, T.G., 1973, Summary ground-water resources of Washington County, Pennsylvania: Pennsylvania Geologic Survey, Water Resource Report 38, 32 p., 1 pl. without scale. [Also available at http://www.denr.state.pa.us/topogeo/publications/pgspub/water/index.htm.]

Nickelsen, P.N., and Hough, V.N.D., 1967, Jointing in the Appalachian plateau of Pennsylvania: Geological Society of America Bulletin 78, p. 609-630. [Also available at http://gsabulletin.gsapubs.org/content/78/5/609.abstract.]

Pennsylvania Department of Environmental Protection [PADEP], 2015, DEP GreenPort: PADEP web page, accessed June 6, 2015; at http://www.dep.pa.gov/DataandTools/Reports/Oil\%20 and\%20Gas\%20Reports/Pages/default.aspx.

Schweinfurth, S.P., 1976, Geologic map of the Avella quadrangle and part of the Steubenville East quadrangle, Washington County, Pennsylvania: U.S. Geological Survey Miscellaneous Investigation Series Map I-908, scale 1:24,000. [Also available at https://pubs.er.usgs.gov/publication/i908.] [Prepared in cooperation with The Pennsylvania Department of Environmental Resources, Bureau of Topographic and Geologic Survey.]

Shaw, E.W., and Munn, M.J., 1911, Burgettstown-Carnegie folio, Pennsylvania - Folios of the Geologic Atlas 177: U.S. Geological Survey, 16 p., 8 quadrangles. [Also available at https://pubs.er.usgs.gov/publication/gf177.]

Skema, V.W., 1987, Coal resources of Washington County, Pennsylvania-Part 1; Coal crop lines, mined-out areas, and structure contours: Pennsylvania Geologic Survey, Fourth Series, Minerals Resource Report 93, 96 p. [Also available at http://www.dcnr.state.pa.us/topogeo/publications/pgspub/ mineral/index.htm.]

Williams, D.R., Felbinger, J.K., and Squillace, P.J., 1993, Water resources and the hydrologic effects of coal mining in Washington County, Pennsylvania, U.S. Geological Survey Open-File Report 89-620, 226 p. [Also available at https://pubs.er.usgs.gov/publication/ofr89620.] 


\section{Appendix 1. Lithologic Descriptions of Stratigraphic Units Exposed in the Avella 7.5-Minute Quadrangle, Washington County, Pennsylvania}

Lithologic descriptions of stratigraphic units are presented here in descending order, and are repeated from Schweinfurth (1976) from units exposed in the Avella 7.5-minute geologic quadrangle, Washington County, Pennsylvania. Thicknesses are provided in in feet $(\mathrm{ft})$ and in meters $(\mathrm{m})$.

\section{Alluvium and landslide deposits $(\sim 10 \mathrm{ft}, \sim 3 \mathrm{~m})$}

Alluvium: Unconsolidated clay, silt, sand, gravel, and cobbles in and adjacent to streams.

Landslide deposits: Unconsolidated, slumped hummocky masses of soil with rock fragments.

\section{Dunkard Group}

\section{Greene Formation $(60+\mathrm{ft}, 18.3+\mathrm{m})$}

Very poorly exposed; probably consists mostly of mudstone containing thin beds of siltstone and fine-grained sandstone. Several massive beds of fine- to medium-grained sandstone probably also occur because abundant sandstone float was observed. Sandstone float is tan, micaceous, feldspathic, argillaceous, moderately friable, in small chips to blocks as much as $1 \mathrm{ft}(0.3 \mathrm{~m})$ square by six inches $(15 \mathrm{~cm})$ thick. A persistent, thin carbonaceous shale bed occurs at the base.

\section{Washington Formation (160-200 ft, 48-61 m)}

Upper limestone member: Mostly limestone. Limestone is light gray to medium dark gray, weathers white to orange, is very fine grained, argillaceous, locally siliceous, in part detrital, in beds a few inches (about $5 \mathrm{~cm})$ to $3 \mathrm{ft}(0.9 \mathrm{~m})$ thick separated by thin beds of clay; some beds are laminated suggesting algal structure; some beds have contemporaneous shrinkage cracks and solution features; fossils include freshwater ostracods, Spirorbis, fish remains, and small pelecypods and gastropods.

Middle limestone member: Mostly limestone in sequences 10 to $30 \mathrm{ft}$ (3-9 m) thick; mudstone containing thin beds of siltstone; and one or two sandstone beds as much as $5 \mathrm{ft}(1.5 \mathrm{~m})$ thick. A thin, argillaceous coal bed and carbonaceous shale occur locally about $25 \mathrm{ft}(7.6 \mathrm{~m})$ below the top. Limestone is light gray to dark gray, weathers white to orange, is argillaceous to very argillaceous, locally siliceous, very fine grained, in beds a few inches (about $5 \mathrm{~cm})$ to $3 \mathrm{ft}(0.9 \mathrm{~m})$ thick; fossils include freshwater ostracods, fish remains, and small gastropods and pelecypods. Mudstone is medium to dark gray, weathers light tan, is poorly bedded, micaceous, and contains small siderite nodules scattered throughout. Sandstone is light gray, weathers tan to brown, is fine to medium grained, micaceous, feldspathic, argillaceous, moderately friable to hard, medium to massive bedded and locally crossbedded. A thin carbonaceous shale occurs locally at the base.

Lower limestone member: Mostly limestone in the upper part and a thick Washington coal bed in the lower part. Coal bed is mostly interbedded clay and coal locally 5 to $8 \mathrm{ft}(1.5-2.4 \mathrm{~m})$ thick, grades laterally to carbonaceous shale and claystone with persistent bed of coal 1 to $2 \mathrm{ft}(0.3-0.6 \mathrm{~m})$ thick at the base. Limestone is light gray to dark gray, weathers white to orange, is very fine grained, argillaceous, locally siliceous to very siliceous, in part detrital, in beds a few inches (about $5 \mathrm{~cm}$ ) to $2 \mathrm{ft}(0.6 \mathrm{~m})$ thick separated by thin beds of clay; some beds are laminated suggesting algal structure; some beds have contemporaneous shrinkage cracks and solution features; fossils include freshwater ostracods, fish remains, and small pelecypods and gastropods. Claystone and carbonaceous shale are medium gray to black and weather tan to light gray.

\section{Waynesburg Formation (85-120 ft, 26-36.5 m)}

Upper and middle members: Mostly interfingered beds of mudstone, shale, and limestone, with several sandstone beds 3 to $5 \mathrm{ft}(0.9-1.5 \mathrm{~m})$ thick, and a thin nonpersistent coal bed tentatively identified as the Waynesburg "B" coal bed about $25 \mathrm{ft}$ (7.6 m) above base. Mudstone, limestone, and sandstone are similar to those described for middle member of Washington Formation. Shale is medium gray, weathers buff, is fissile and micaceous. Waynesburg " $\mathrm{A}$ " coal bed at base is a few inches (about $5 \mathrm{~cm}$ ) to $8 \mathrm{ft}(2.4 \mathrm{~m})$ thick, generally argillaceous, with numerous clay partings.

Lower member: Mostly mudstone containing thin beds of siltstone and fine-grained sandstone; limestone in several lenticular beds, one as much as $8 \mathrm{ft}(2.4 \mathrm{~m})$ thick at the top, one as much as $3 \mathrm{ft}(0.9 \mathrm{~m})$ thick near the middle, and one persistent bed, one foot $(0.3 \mathrm{~m})$ thick, generally about 5 to $10 \mathrm{ft}(1.5-3.0 \mathrm{~m})$ above the base; sandstone, locally massive, as much as $25 \mathrm{ft}(7.6 \mathrm{~m})$ thick, in lower part. Mudstone is medium gray, weathers light tan, is poorly bedded, micaceous, contains small siderite nodules scattered throughout, and is locally calcareous. Sandstone is light gray, weathers tan to brown, is fine to medium grained, micaceous, feldspathic, argillaceous, moderately friable, thin to massive bedded, and generally crossbedded. Limestone is medium gray, weathers buff to orange, is very fine grained, very argillaceous, locally carbonaceous in beds a few inches (about $5 \mathrm{~cm})$ to $2 \mathrm{ft}(0.5 \mathrm{~m})$ thick; the lowest limestone bed is commonly overlain by carbonaceous shale a few inches (about $5 \mathrm{~cm}$ ) to about $1 \mathrm{ft}$ $(0.3 \mathrm{~m})$ thick. Waynesburg coal bed at base ranges in thickness from 1 to $6 \mathrm{ft}(0.3-1.8 \mathrm{~m})$. Coal is commonly argillaceous and bony and is interbedded with carbonaceous shale and clay. 


\section{Monongahela Group}

\section{Uniontown Formation (45-55 ft, 13.7-16.7 m)}

Upper member: Mostly mudstone containing thin beds of siltstone and fine-grained sandstone with locally massive sandstone, as much as $18 \mathrm{ft}(5.9 \mathrm{~m})$ thick. Mudstone and sandstone are similar to those in lower member of Waynesburg Formation. Little Waynesburg coal bed at base, nonpersistent, locally as much as $5 \mathrm{ft}(1.5 \mathrm{~m})$ thick, predominantly carbonaceous shale but includes some thin coal.

Lower member: Mostly mudstone containing thin beds of siltstone and fine-grained sandstone; sandstone, as much as $25 \mathrm{ft}(7.6 \mathrm{~m})$ thick locally; and a persistent limestone and marl zone at the top of the member, as much as $5 \mathrm{ft}(1.5 \mathrm{~m})$ thick. Mudstone and sandstone are similar to those in lower part of Waynesburg Formation. Limestone and marl are light gray to dark gray, weather buff to tan, are generally very argillaceous but become more calcareous upward, very fine grained, in beds 1 to $3 \mathrm{ft}(0.3-0.9 \mathrm{~m})$ thick; fossils include freshwater ostracods, fish remains, and small gastropods and pelecypods. Uniontown coal bed at base, nonpersistent, generally less than $1 \mathrm{ft}(0.3 \mathrm{~m})$ thick, argillaceous, grades laterally to carbonaceous shale.

\section{Pittsburgh Formation (230-270 ft, 70-82.3 m)}

Upper member: Typically alternating sequences of limestone and characteristic greenish-gray shale and mudstone containing calcareous siltstone locally. Limestone sequences are 5-15 ft $(1.5-4.5 \mathrm{~m})$ thick and are roughly divisible into four more or less persistent beds, a, b, c, and d, in ascending order; in some areas two sequences, such as beds a and $\mathrm{b}$ or $\mathrm{c}$ and $\mathrm{d}$, form a vertically continuous limestone, but individual sequences are generally separated by beds of shale, mudstone, and siltstone 3 to $15 \mathrm{ft}(0.9-4.5 \mathrm{~m})$ thick. Sandstone, as much as $3 \mathrm{ft}(0.9 \mathrm{~m})$ thick, occurs locally at base of member. Limestone is light to dark gray, very fine grained, very argillaceous, in part a sedimentary breccia; in beds a few inches (about $5 \mathrm{~cm})$ to $3 \mathrm{ft}(0.9 \mathrm{~m})$ thick with thin interbeds of gray and greenish-gray clay; some beds are laminated suggesting algal structure, and some beds have contemporaneous shrinkage and solution features, uppermost bed of each sequence is generally more calcareous; fossils include freshwater ostracods, Spirorbis, fish remains, and small gastropods and pelecypods. Sandstone is dark greenish gray, weathers dark brown, is fine grained, micaceous, feldspathic, locally calcareous, generally hard, and thin to medium bedded. Mudstone and shale, except for greenishgray color, are similar to those in the lower member of the Waynesburg Formation.

Sewickley Member: Mostly limestone; lower 1 to $2 \mathrm{ft}$ $(0.3-0.6 \mathrm{~m})$ generally calcareous claystone and clay. Limestone is light to dark gray, buff to orange weathering with characteristic hackly fracture pattern, very argillaceous, very fine grained, locally slightly cherty, in part a sedimentary breccia; in beds a few inches (about $5 \mathrm{~cm})$ to $3 \mathrm{ft}(0.9 \mathrm{~m})$ thick with thin interbeds of gray clay. Some limestone beds are laminated suggesting algal structure; some have contemporaneous shrinkage cracks and solution features; fossils include freshwater ostracods, fish remains, and small pelecypods and gastropods. Claystone and mudstone are medium to dark gray, weather gray to buff, and are calcareous and poorly bedded.

Fishpot Member: Mostly mudstone containing thin beds of siltstone and very fine grained sandstone; sandstone, locally massive, as much as $15 \mathrm{ft}(4.5 \mathrm{~m})$ thick. Mudstone and sandstone are similar to those in lower member of Waynesburg Formation, except that the sandstone is generally thin bedded with much carbonaceous material on bedding planes. Carbonaceous shale bed, thin, locally present at base; possibly represents Fishpot coal bed.

Redstone Member: Interfingered beds of mudstone, limestone, claystone, and shale. A limestone zone 5 to $17 \mathrm{ft}$ $(1.5-5.2 \mathrm{~m})$ thick characteristically present at top. Limestone and claystone similar to those in the Sewickley Member of the Pittsburgh Formation. Mudstone is similar to that in the lower member of the Waynesburg Formation. Redstone coal bed at base, nonpersistent, argillaceous, as much as $1 \mathrm{ft}$ $(0.3 \mathrm{~m})$ thick, grades laterally into carbonaceous shale.

Lower member: Mostly interfingered beds of limestone, mudstone, and claystone, with locally massive sandstone as much as $50 \mathrm{ft}(15.2 \mathrm{~m})$ thick. The sandstone may occur in channels eroded partly or entirely through the Pittsburgh coal bed. Limestone and claystone are similar to those in the Sewickley Member of the Pittsburgh Formation. Mudstone, similar to that in the lower member of the Waynesburg Formation. Sandstone, similar to that in lower member of the Uniontown Formation. Pittsburgh Rider coal bed about $20 \mathrm{ft}$ (6 m) above base of member, nonpersistent, argillaceous, 0 to $1 \mathrm{ft}(0-0.3 \mathrm{~m})$ thick. Pittsburgh coal bed at base, persistent, commonly in two benches, the lower bench averaging 58 inches $(147 \mathrm{~cm})$ in thickness.

\section{Conemaugh Group}

\section{Casselman Formation $(\sim 220 \mathrm{ft}, \sim 67 \mathrm{~m})$}

Mostly variegated mudstone and claystone containing thin to medium beds of siltstone and fine- to medium-grained sandstone. Near the top of the formation two limestone sequences 0 to $10 \mathrm{ft}(0-3 \mathrm{~m})$ and 0 to $7 \mathrm{ft}(0-2.1 \mathrm{~m})$ thick occur separated by about 5 to $7 \mathrm{ft}(1.5-2.1 \mathrm{~m})$ of interbedded fine-grained sandstone and mudstone, and a very massive sandstone bed, as much as $70 \mathrm{ft}(21.3 \mathrm{~m})$ thick, occurs in the middle. Mudstone is medium to dark gray, gray green, and maroon, weathers tan, olive, and brown, is poorly bedded, micaceous, and contains small siderite nodules scattered 
throughout and occasional zones of small lime nodules. Claystone is gray and maroon, weathers gray to brown, and is poorly bedded. Sandstone is light to medium gray, weathers medium brown, is fine to coarse grained, micaceous, feldspathic, argillaceous, medium to massive bedded and locally crossbedded. Limestone is similar to that in the Sewickley Member of the Pittsburgh Formation.

\section{Glenshaw Formation $(100+\mathrm{ft}, \mathbf{3 0 . 5 +} \mathrm{m})$}

Mostly mudstone that contains thin to medium beds of siltstone and sandstone similar to that in the Casselman Formation. Ames Limestone Member at top is about $3 \mathrm{ft}$ $(0.9 \mathrm{~m})$ thick, distinctive, and persistent. Limestone is dark gray, weathers dark gray, is medium to coarse grained, and thin to medium bedded; fossils include brachiopods and crinoid stem fragments. 

